\title{
EFEITO DE LÂMINAS DE IRRIGAÇÃO E DOSES DE CONDICIONADOR, ASSOCIADAS A DIFERENTES TAMANHOS DE TUBETES, NA PRODUÇÃO DE MUDAS DE CAFEEIRO
}

ELIEZER SANTURBANO GERVÁSIO

Tese apresentada à Escola Superior de Agricultura "Luiz de Queiroz", Universidade de São Paulo, para obtenção do título de Doutor em Agronomia, Área de Concentração: Irrigação e Drenagem.

PIRACICABA

Estado de São Paulo - Brasil

Junho - 2003 


\title{
EFEITO DE LÂMINAS DE IRRIGAÇÃO E DOSES DE CONDICIONADOR, ASSOCIADAS A DIFERENTES TAMANHOS DE TUBETES, NA PRODUÇÃO DE MUDAS DE CAFEEIRO
}

\section{ELIEZER SANTURBANO GERVÁSIO}

Engenheiro Agrônomo

Orientador: Prof. Dr. JOSÉ ANTÔNIO FRIZZONE

Tese apresentada à Escola Superior de Agricultura "Luiz de Queiroz", Universidade de São Paulo, para obtenção do título de Doutor em Agronomia, Área de Concentração: Irrigação e Drenagem.

\author{
PIRACICABA \\ Estado de São Paulo - Brasil \\ Junho - 2003
}




\section{Dados Internacionais de Catalogação na Publicação (CIP)} DIVISÃO DE BIBLIOTECA E DOCUMENTAÇÃO - ESALQ/USP

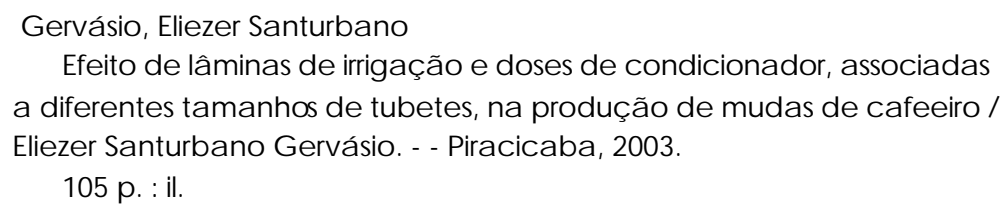

Tese (doutorado) - Escola Superior de Agricultura Luiz de Queiroz, 2003. Bibliografia.

1. Café 2. Cultivo em viveiro 3. Imiga ção 4. Mudas- produção I. Título

CDD 633.73 
Aos meus familiares, em especial aos meus pais Nivaldo (in memorian), sempre presente, e Neusa, exemplo de garra e perseverança

\section{OFEREÇO}

À minha esposa Rita de Cássia,

Pela compreensão, incentivo e carinho

DEDICO 


\section{AGRADECIMENTOS}

À Deus, pela saúde e perseverança;

Ao Departamento de Engenharia Rural da Escola Superior de Agricultura "Luiz de Queiroz", pela oportunidade concedida para a realização do curso de doutorado;

À Coordenadoria de Aperfeiçoamento de Pessoal de Nível Superior (CAPES), pela concessão da bolsa de estudo e à Fundação de Amparo à Pesquisa do Estado de São Paulo (FAPESP), pelo apoio financeiro oferecido na realização desse trabalho;

Ao Prof. Dr. José Antônio Frizzone pela orientação, ensinamento e amizade;

Ao Prof. Dr. Marcos Vinicius Folegatti, pelo apoio oferecido na realização desse trabalho;

Aos professores Dr. Tarlei Arriel Botrel, Dr. Sérgio Nascimento Duarte e Dr. Rubens Duarte Coelho, pelas valiosas sugestões e ensinamentos e aos demais professores que contribuíram para a minha formação acadêmica;

Ao Prof. Dr. Manoel Alves de Faria, da Universidade Federal de Lavras (UFLA), pela amizade, ensinamentos e indicação ao curso de doutorado na ESALQUSP;

Ao Prof. Dr. Alberto Colombo, da Universidade Federal de Lavras (UFLA), primeira pessoa que me incentivou no estudo da Irrigação e Drenagem;

Aos amigos do curso de pós-graduação em Irrigação e Drenagem, pelo convívio e respeito;

Aos funcionários do LER/ESALQ/USP, pelos auxílios prestados. 


\section{SUMÁRIO}

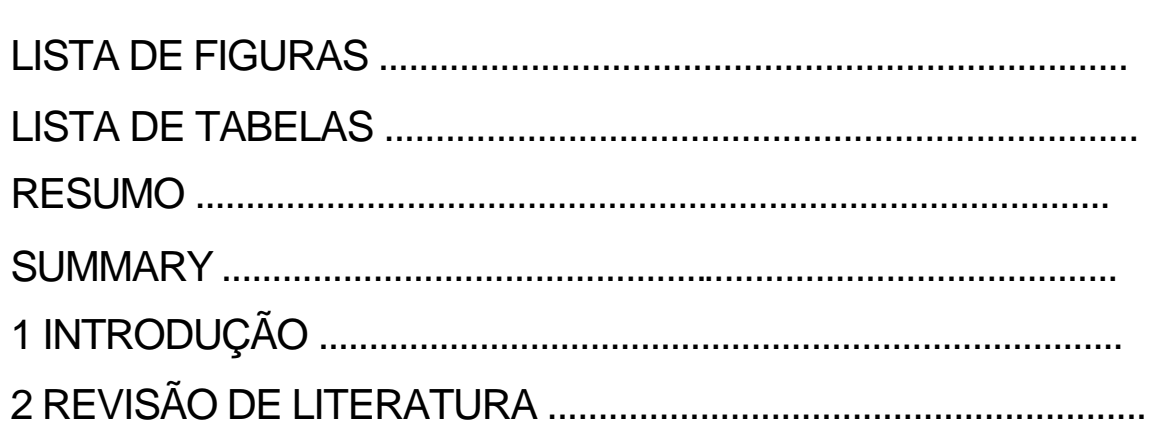

Página viii $\mathrm{xi}$ xii XV

2.1 Produção de mudas de cafeeiro em tubetes

2.2 Manejo da irrigação na produção de mudas e em cultivos em recipientes

2.2.2 Manejo da irrigação na produção de mudas de cafeeiro em tubetes

2.3 Uso de polímeros hidroabsorventes na agricultura

2.3.1 Efeitos dos polímeros hidroabsorventes no sistema soloplanta

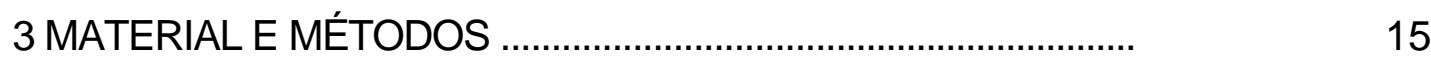

3.1 Local do experimento ............................................................. 15

3.2 Delineamento experimental ..................................................... 16

3.3 Semeadura ........................................................................ 18

3.4 Componentes do substrato ................................................... 18 


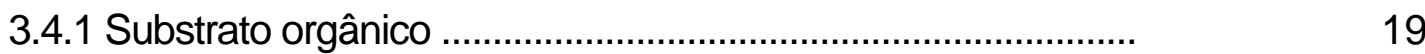

3.4.2 Fertilizante de liberação controlada ............................................

3.4.3 Condicionador ......................................................................

3.5 Preparo do substrato e enchimento dos tubetes ..........................

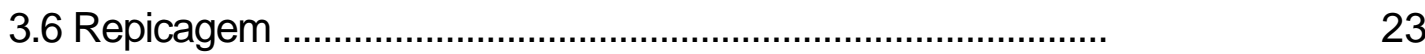

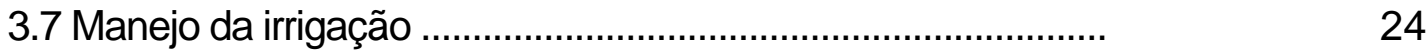

3.8 Eficiência da irrigação ..........................................................

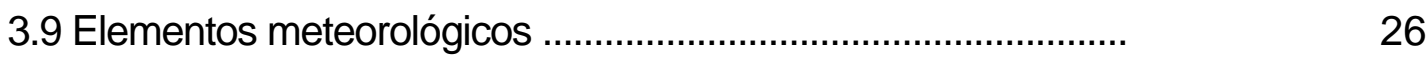

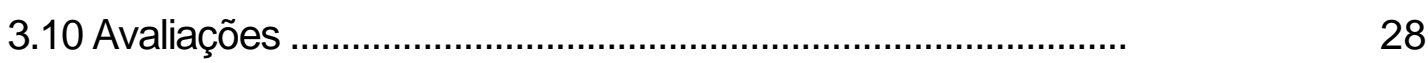

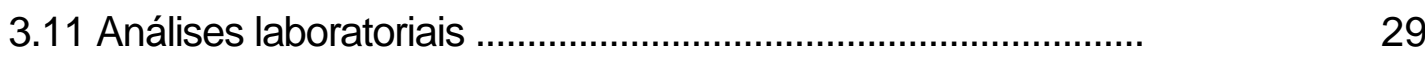

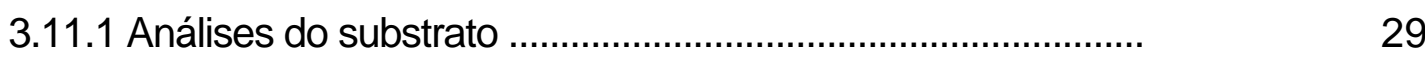

3.11.1.1 Curva característica de retenção de água ............................. 29

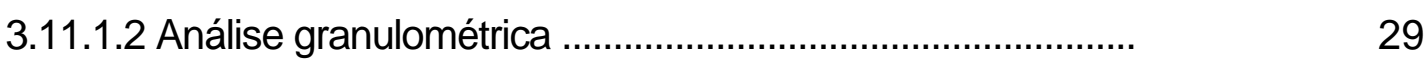

3.11.1.3 Condutividade hidráulica do substrato saturado ................... 30

3.11.1.4 Condutividade elétrica do extrato saturado ......................... 31

3.11.2 Análises do condicionador ..................................................... 32

3.11.2.1 Absorção do condicionador ...................................................

3.11.2.2 Absorção do condicionador em solução fertilizante .............. 33

3.11.2.3 Reabsorção do condicionador .............................................. 33

4 RESULTADOS E DISCUSSÃO .....................................................

4.1 Propriedades físico-hídricas do substrato ....................................

4.2 Propriedades físico-hídricas e químicas do condicionador ........... 42

4.3 Aspectos relacionados àirrigação ................................................

4.4 Desenvolvimento vegetativo ......................................................

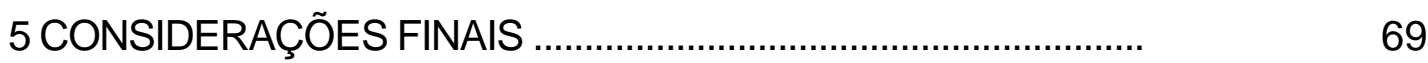

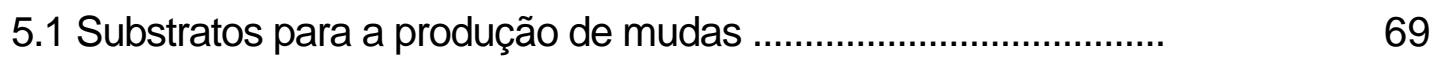

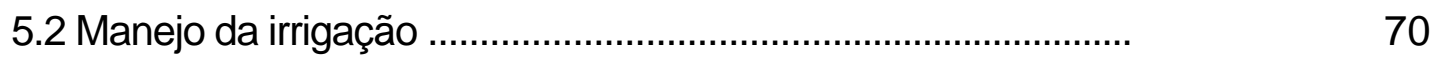

5.3 Utilização de condicionador na produção de mudas ....................

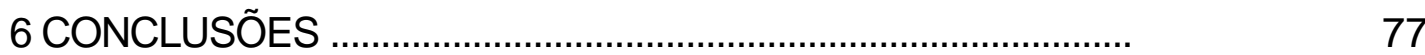


REFERÊNCIAS BIBLIOGRÁFICAS 


\section{LISTA DE FIGURAS}

Página

1 Croqui da área experimental ................................................... 17

2 Muda de cafeeiro no estádio "palito de fósforo" ........................... 24

3 Curvas características de retenção de água do substrato nas doses de 0 e $10 \mathrm{~kg} \mathrm{~m}^{-3}$ de condicionador .................................... 38

4 Condutividade hidráulica do substrato saturado em função de doses do condicionador, em duas metodologias de determinação

5 Curva de absorção do condicionador em função do tempo ...........

6 Curva de absorção do condicionador em função da condutividade elétrica da solução

7 Reabsorção do condicionador em água destilada após hidratação inicial em solução salina

8 Percentual equivalente da lâmina controle em relação a evaporação do minitanque, durante todo período experimental ..

9 Lâmina planejada (meta) e lâminas reais armazenadas nos tubetes, em função dos valores percentuais da evaporação no minitanque, durante 0 período experimental. Lâminas acumuladas aos 57 DAR (a), aos 88 DAR (b), aos 118 DAR (c) e aos 149 DAR (d)

10 Arquitetura foliar de mudas de cafeeiro. Muda que converge água para o interior do tubete (a) e muda que não converge água simulando efeito "guarda-chuva" (b) 
11 Selamento superficial devido ao desenvolvimento de algas. Fase inicial com aspecto pastoso (a) e película seca e impermeável à infiltração de água (b)

12 Mortalidade de mudas de cafeeiro em função das lâminas de irrigação e tamanhos de tubetes, durante o período experimental

13 Eficiência da irrigação para mudas cultivadas em tubetes de 120 $\mathrm{cm}^{3}$ e irrigadas com a lâmina controle

14 Desenvolvimento vegetativo de mudas de cafeeiro irrigadas com a lâmina controle, cultivadas em substrato com diferentes doses do condicionador. Altura, diâmetro do caule e área foliar

15 Desenvolvimento vegetativo de mudas de cafeeiro irrigadas com a lâmina controle, em função de diferentes doses do condicionador. Matérias secas da parte aérea, sistema radicular e total

16 Relação parte aérea-sistema radicular, área foliar específica e eficiência do uso da água de mudas de cafeeiro irrigadas com a lâmina controle, em função de diferentes doses do condicionador

17 Sintomas de necrose na região do colo em mudas de cafeeiro. Fase inicial (a) e estádio avançado estendendo-se ao longo do caule (b)

18 Condutividade elétrica do extrato saturado do substrato ao longo do período experimental, sob diferentes lâminas de irrigação e tamanhos de tubetes

A1 Minitanque automático. Vista geral (a) e (e), válvula solenóide e circuito eletrônico (b), sensores de controle do nível de água (c) e sensor de pressão instalado na base inferior do tubo de PVC (d)

A2 Circuito eletrônico para controle do nível de água no minitanque 
A4 Ensaio de laboratório para a obtenção da equação de calibração do sensor

B1 Barra de irrigação acoplada ao carrinho (a); cremalheira e mangueira fixa ao rolamento (b)

B2 Diagrama de funcionamento do sistema de irrigação automatizado

B3 Programa desenvolvido na linguagem Delphi 4.0 para automação do sistema de irrigação

B4 Fonte 127VAC/12VCC (a); circuito ótico-isolado para ligar a motobomba (b); circuito ótico-isolado para ligar o moto-redutor (c)

B5 Circuito ótico-isolado para inverter o sentido de rotação do motoredutor (a); circuito ótico-isolado para ligar a válvula solenóide esquerda (b); circuito ótico-isolado para ligar a válvula solenóide direita (c)

B6 Perfil de distribuição de água da barra de irrigação

B7 Detalhe do sensor de posição e do imã responsável pelo fechamento do circuito 


\section{LISTA DE TABELAS}

Página

1 Caracterização física e química do substrato orgânico .................. 20

2 Composição química do fertilizante de liberação controlada ......... 21

3 Características químicas e físicas do TerraCottem ${ }^{\circledR}$...................... 22

4 Distribuição granulométrica do substrato ........................................ 35

5 Modelo de van Genuchten para ajuste da CCRA em função de doses de condicionador adicionadas ao substrato ........................ 37

6 Armazenamento de água (\% volume) em função de doses do condicionador adicionadas ao substrato ........................................

7 Dados meteorológicos monitorados no interior da casa de vegetação durante o período experimental ...................................

8 Análise estatística das variáveis altura, diâmetro do caule e área foliar de mudas de cafeeiro, irrigadas com a lâmina controle, no final do experimento

9 Teores de macro e micronutrientes em função de lâminas de irrigação e tamanhos de tubetes

10 Teores foliares de cloro, sódio e boro $\left(\mathrm{mg} \mathrm{kg}^{-1}\right)$ em função da lâmina de irrigação

B1 Resultados da avaliação do sistema de irrigação 


\title{
EFEITO DE LÂMINAS DE IRRIGAÇÃO E DOSES DE CONDICIONADOR, ASSOCIADAS A DIFERENTES TAMANHOS DE TUBETES, NA PRODUÇÃO DE MUDAS DE CAFEEIRO
}

\author{
Autor: ELIEZER SANTURBANO GERVÁSIO \\ Orientador: Prof. Dr. JOSÉ ANTÔNIO FRIZZONE
}

\section{RESUMO}

Avaliaram-se, em casa de vegetação, as interações entre tamanho de tubetes, quantidade de água e doses de um condicionador, ra produção de mudas de cafeeiro. Adotou-se o delineamento experimental de blocos casualizados em esquema de parcelas sub-subdivididas com 4 repetições. As parcelas foram constituídas por lâminas de irrigação, sendo 4 níveis baseados na evaporação (EV) de um minitanque automatizado (50, 75, 100 e $125 \%$ da EV) e um nível adicional, denominado controle. Essas parcelas foram representadas por 20 bancadas, sendo cada uma dividida em duas subparcelas, representadas por tubetes de diferentes volumes $\left(60\right.$ e $\left.120 \mathrm{~cm}^{3}\right)$. Finalmente, nas sub-subparcelas, foram avaliadas diferentes doses do condicionador TerraCottem ${ }^{\circledR}\left(0 ; 2,5 ; 5 ; 7,5\right.$ e $10 \mathrm{~kg} \mathrm{~m}^{-3}$ de substrato). A avaliação das propriedades físico-hídricas do substrato mostrou que o mesmo apresenta características de retenção de água em função de sua granulometria. Verificou-se também, que o ganho em retenção de água com a adição do condicionador ao substrato ocorreu até a tensão de $10 \mathrm{kPa}$. Os valores da 
condutividade hidráulica do substrato saturado diminuíram com o aumento da dose do condicionador, sendo essa diminuição devido à expansão do condicionador e conseqüente redução da macroporosidade e permeabilidade do material. Com relação à propriedades físico-hídricas e químicas do condicionador, os resultados obtidos em laboratório, principalmente em termos de absorção e reabsorção, não foram os mesmos quando da sua utilização em condições de cultivo. Aspectos relacionados à irrigação mostraram que a arquitetura e a área foliar das mudas de cafeeiro afetam a eficiência e a uniformidade da irrigação. Observou-se, também, que os níveis de lâminas, baseados na evaporação do minitanque, foram insuficientes para 0 desenvolvimento adequado das mudas, o que refletiu em elevados níveis de mortalidade das plantas. O maior desenvolvimento vegetativo foi obtido com a aplicação da lâmina controle, embora as mudas não tenham apresentado um padrão comercial desejado. Nessa lâmina de irrigação, verificou-se que as mudas de cafeeiro que se desenvolveram nos tubetes de $120 \mathrm{~cm}^{3}$ foram superiores àquelas cultivadas nos tubetes de $60 \mathrm{~cm}^{3}$, para as variáveis vegetativas altura, diâmetro do caule e área foliar. No período compreendido entre os 118 e 149 DAR (dias após a repicagem), foi observado um aumento considerável no desenvolvimento das mudas, principalmente em termos de altura, área foliar e produção de biomassa . Esse incremento foi devido àqueda acentuada nos valores da condutividade elétrica do extrato saturado, que ao final do experimento foram de $3,15 \mathrm{dS} \mathrm{m}^{-1}$ e 2,45 dS $\mathrm{m}^{-1}$, para os tubetes de 60 $\mathrm{cm}^{3}$ e $120 \mathrm{~cm}^{3}$, respectivamente. Nas condições em que o experimento foi conduzido, concluiu-se que para o bom desenvolvimento da muda são necessárias lâminas de irrigação superiores a $600 \mathrm{~mm}$, principalmente quando o umedecimento inicial do substrato não é adequado; o tubete de $120 \mathrm{~cm}^{3}$ possibilitou um maior desenvolvimento vegetativo das mudas; não houve efeito de doses do condicionador no desenvolvimento das mudas de cafeeiro mostrando que quando o objetivo é a retenção de água, os polímeros 
hidroabsorventes perdem sua efetividade ao serem adicionados em meios de cultivo intensivos. 


\title{
EFFECT OF IRRIGATION DEPTHS AND DOSES OF SOIL CONDITIONER, ASSOCIATED TO DIFFERENT SIZES OF PLASTIC TUBES, IN THE PRODUCTION OF COFFEE SEEDLINGS
}

\author{
Author: ELIEZER SANTURBANO GERVÁSIO \\ Adviser: Prof. Dr. JOSÉ ANTÔNIO FRIZZONE
}

\section{SUMMARY}

They were evaluated, in greenhouse, the interactions among plastic tubes size, amount of water and doses of a soil conditioner, in the production of coffee seedlings. The experimental design was in split-split-plot randomized blocks with 4 replications. Plots were constituted by irrigation depths, being 4 levels based on the evaporation (EV) of an automated mini-pan (50, 75, 100 and $125 \%$ of EV) and an additional level, denominated control. Those plots were represented by 20 benches, being each one divided into two sub-plots, constituted of plastic tubes of different volumes $\left(60\right.$ and $\left.120 \mathrm{~cm}^{3}\right)$. Finally, in the sub-sub-plots, different doses of conditioner TerraCottem ${ }^{\circledR}(0 ; 2.5 ; 5 ; 7.5$ and 10 $\mathrm{kg} \mathrm{m}^{-3}$ of substrate) were evaluated. The evaluation of the physical-hydrical properties of the substrate showed that it presents characteristics of water retention as a function of its granulometry. It was also verified that the increase of water retention with the addition of the soil conditioner to the substrate occurred until a tension of $10 \mathrm{kPa}$. The values of the hydraulic conductivity of the saturated substrate decreased with the increase of the soil conditioner dose, 
being that decrease due to the conditioner expansion and consequent reduction of the macroporosity and permeability of the material. Regarding the physicalhydrical and chemical properties of the soil conditioner, the results obtained at laboratory, mainly in absorption and reabsorption terms, we re not the same ones when compared with its use in cultivation conditions. Aspects related to irrigation showed that the architecture and the leaf area of the coffee seedlings affect the efficiency and the uniformity of irrigation. It was also observed that the levels of irrigation depth, based on the evaporation of the mini-pan, were not sufficient for the appropriate development of the seedlings, which resulted in high levels of mortality of the plants. The highest vegetative development was obtained with the application of the control irrigation depth, although the seedlings have not presented a desired commercial standard. In that irrigation depth, it was verified that the coffee seedlings that grew in the plastic tube of $120 \mathrm{~cm}^{3}$ were higher than those aultivated in the plastic tubes of $60 \mathrm{~cm}^{3}$, for the vegetative variables height, stem diameter and leaf area. In the period between 118 and 149 DAT (days after transplanting), a considerable increase was observed in the development of the seedlings, mainly in height, leaf area and biomass production terms. This increment was due to the accentuated decrease in the electric conductivity values of the saturated extract, which were $3.15 \mathrm{dS}$ $\mathrm{m}^{-1}$ and $2.45 \mathrm{dS} \mathrm{m}^{-1}$ at the end of the experiment for the plastic tubes of $60 \mathrm{~cm}^{3}$ and $120 \mathrm{~cm}^{3}$, respectively. Under the conditions that the experiment was conducted, it was concluded that irrigation depths above $600 \mathrm{~mm}$ are required for the good development of the seedling, mainly when the initial moistening of the substrate is not adequate; the plastic tube of $120 \mathrm{~cm}^{3}$ made possible a higher vegetative development of the seedlings; there was no effect of doses of the soil conditioner in the development of the coffee seedlings showing that when the objective is the retention of water, the hydroabsorbents polymers lose their effectiveness when they are added to intensive cultivation media. 


\section{INTRODUÇÃO}

O Brasil é o maior produtor e exportador mundial de café, o que faz da cafeicultura uma atividade de grande expressão no cenário agroindustrial brasileiro. A necessidade do setor cafeeiro em aumentar a eficiência produtiva, acompanhada da redução dos custos de produção para uma maior competitividade, faz com que surja a busca de novas tecnologias.

$\mathrm{Na}$ implantação da lavoura cafeeira, vários são os fatores que contribuem para o seu sucesso, dentre os quais, a utilização de mudas sadias e bem desenvolvidas. Elas são a base da sustentação da lavoura, principalmente por se tratar de uma cultura perene. Assim, a produção de mudas e a implantação dos viveiros, sobretudo utilizando-se cultivares melhoradas, devem ser feitas de forma criteriosa, pois as mudas com boa qualidade proporcionarão um desenvolvimento uniforme da lavoura, uma melhor produção inicial e um maior rendimento por área.

No Brasil, prevalece o sistema tradicional de produção de mudas de cafeeiro em saquinhos de polietileno. Entretanto, em virtude do referido sistema apresentar alguns inconvenientes como, maior custo no transporte, menor rendimento no plantio e necessidade de maior volume de substrato, a geração de novas tecnologias para a produção de mudas de cafeeiro tornou-se necessária. A produção de mudas em tubetes com um substrato adequado tem como principal objetivo a obtenção de mudas com um sistema radicular bem desenvolvido, com maior vigor vegetativo, livre de pragas, doenças e plantas daninhas. 
Acredita-se que atualmente, o cenário de produção de mudas de cafeeiro encontra-se numa fase de transição, em que aos poucos, o sistema tradicional vem sendo substituído pelo sistema de tubetes. A grande diferença que existe entre os dois sistemas de produção de mudas refere-se ao volume do recipiente disponível para o desenvolvimento da muda. Os tubetes normalmente utilizados para a produção de mudas de cafeeiro apresentam um volume menor do que os saquinhos de polietileno. Dessa forma, os substratos utilizados nesses recipientes devem apresentar elevada porosidade, para possibilitar æ̀̀ mudas uma maior eficiência nas trocas gasosas $\left(\mathrm{CO}_{2}\right.$ e $\left.\mathrm{O}_{2}\right)$. Ao mesmo tempo, esses substratos devem apresentar boas características de retenção de água para suprir as necessidades da planta. Aspectos relacionados ao tamanho, fertilização e utilização de diferentes substratos na produção de mudas em tubetes tem sido o enfoque principal dos pesquisadores. Poucas informações sobre irrigação de mudas de cafeeiro são encontradas na literatura. As recomendações existentes não levam em consideração a demanda climática local, fazendo com que a resposta da planta seja diferenciada em função do local e da época do ano em que a muda está sendo produzida.

Muitas pesquisas vem sendo realizadas na seleção de materiais para uso como substrato. Misturas que possibilitam aumentar a porosidade para melhorar as trocas gasosas, podem não apresentar características de retenção de água, como o caso de algumas cascas vegetais. Nesse sentido, existe no mercado uma série de condicionadores, dentre eles os polímeros hidroabsorventes, que são utilizados em mistura com esse tipo de material, com o objetivo de aumentar a capacidade de armazenamento de água. Esses materiais surgiram para minimizar os problemas de solos degradados e arenosos, possibilitando o desenvolvimento da agricultura nas regiões mais áridas. Com o aparecimento de uma nova geração de polímeros, as suas aplicações se intensificaram, principalmente em projetos paisagísticos, gramados esportivos, fruticultura e viveiros de mudas. Alguns viveiristas já 
utilizam esses polímeros em mistura com o substrato, obtendo resultados satisfatórios. Entretanto alguns resultados de pesquisa tem sido contraditórios quando da utilização desses polímeros. Existe uma série de fatores que afetam o seu desempenho, como a disponibilidade de água e concentração de sais presentes no substrato, além da resistência do meio oferecida àsua expansão.

Assim, o objetivo do trabalho foi verificar, tecnicamente, as melhores alternativas advindas das interações entre tamanho de tubetes, quantidade de água e doses de um condicionador, na produção de mudas de cafeeiro. 


\section{REVISÃO DE LITERATURA}

\subsection{Produção de mudas de cafeeiro em tubetes}

A produção de mudas de cafeeiro em tubetes surgiu em virtude do sistema atual (produção de mudas em saquinhos) apresentar alguns inconvenientes como a necessidade de um grande volume de substrato, um maior custo no transporte e um menor rendimento no plantio. Apesar desses inconvenientes, a produção de mudas em saquinhos é o sistema mais utilizado no país, representando no Estado de Minas Gerais, 90\% do total de mudas de cafeeiro produzidas. Atualmente, acredita-se que a tecnologia para produção de mudas de cafeeiro passa por uma fase de transição, sendo o sistema de produção em tubetes considerado um procedimento sólido, de fácil condução e com grande aceitação por parte dos produtores (Silva et al., 2000).

Em virtude dessa transição, os trabalhos relacionados a produção de mudas de cafeeiro em tubetes ainda são escassos. Os estudos nessa área estão concentrados, principalmente, nos cultivos de essências florestais (eucalipto e pinus), fruteiras (citros e maracujá) e olerícolas (Guimarães et al., 1998). A maioria dos trabalhos envolvendo a produção de mudas de cafeeiro em tubetes refere-se a aspectos relacionados ao tamanho, fertilização e uso de diferentes substratos. Melo (1999) observou que até o quarto par de folhas, os tubetes com capacidade de $50 \mathrm{~cm}^{3}$ permitiram a produção de mudas de cafeeiro com desenvolvimento semelhante àquelas produzidas em tubetes de $120 \mathrm{~cm}^{3}$, possibilitando uma economia de substrato e redução nos custos com a utilização de tubetes menores. Oliveira et al. (1995), verificaram que a 
fertilização do substrato com fertilizante de liberação lenta proporcionou a obtenção de mudas de melhor qualidade quanto aos aspectos vegetativos e sanitários. Andrade Neto (1998) também verificou efeito semelhante ao aplicar o fertilizante de liberação lenta na formulação 15-10-10 + micronutrientes em mistura com o substrato. Em outro estudo realizado por Melo (1999), sobre doses crescentes de fertilizante de liberação lenta, verificou-se que o substrato comercial enriquecido com fertilizante na dosagem de $8,2 \mathrm{~kg} \mathrm{~m}^{3}$, permitiu 0 maior desenvolvimento das mudas de cafeeiro. Resultados similares foram encontrados por Pozza et al. (2000), onde o maior desenvolvimento das mudas de cafeeiro foi obtido com a aplicação de fertilizante de liberação lenta na dosagem de $8,5 \mathrm{~kg} \mathrm{~m}^{-3}$ em um substrato contendo $80 \%$ de esterco de curral curtido e $20 \%$ de terra de subsolo.

Existem vários trabalhos cujo enfoque é a elaboração de substratos alternativos, nos quais são utilizados resíduos animais e vegetais presentes na propriedade, principalmente estercos e cascas. A possibilidade de inúmeras combinações e comparações desses insumos pode levar, em alguns casos, ao aparecimento de resultados contraditórios entre os autores. Miranda et al. (2001) verificaram que mudas de cafeeiro produzidas em substrato comercial a base de vermiculita, apresentaram desenvolvimento inferior àquelas produzidas nos substratos alternativos. Entretanto, Barbizan et al. (1999), utilizando um substrato comercial composto de casca de pinus, vermiculita, perlita e enriquecido de macro e micronutrientes, constataram um maior desenvolvimento das mudas em saquinhos, em relação àquelas produzidas em substrato alternativo composto de $15 \%$ de cama de frango, $15 \%$ de esterco de curral e $70 \%$ de terra de subsolo, corrigidos com calcário dolomítico na dosagem de $2 \mathrm{~kg} \mathrm{~m}^{-3}$. 


\subsection{Manejo da irrigação na produção de mudas e em cultivos em recipientes}

\subsubsection{Aspectos gerais}

Ao contrário dos cultivos em solo, o manejo da irrigação em recipientes pequenos como o caso dos tubetes, apresenta algumas particularidades como maior freqüência de irrigação, em virtude do reduzido volume de substrato disponível para a planta, além da importância relativa dos fenômenos de advecção. Essas particularidades implicam no risco de estresse hídrico, o qual deve ser prevenido com um maior controle da irrigação. Lemaire et al., citados por Abad et al. (1992), comentaram que na prática, a irrigação em recipientes deve ser feita em excesso, visando conseguir uma uniformidade de distribuição de água no substrato e evitar o acúmulo de sais. Esse excesso deve oscilar entre 10 e $30 \%$ da drenagem, em função da época do ano, do estádio de desenvolvimento da planta e da qualidade da água de irrigação. Milner (2002) recomenda a utilização de um fator de lixiviação no manejo da irrigação em substratos, afim de evitar o acúmulo de sais no sistema. Esse fator depende da qualidade da água utilizada e da sensibilidade da planta à salinidade. Segundo esse autor, essa prática é muito utilizada em Israel e outros países, constituindo-se num preciso método para manejo da irrigação e controle de sais no substrato.

Segundo Wendling \& Gatto (2002), o tipo de substrato utilizado na produção das mudas é de fundamental importância na determinação da freqüência de irrigação e do volume de água a ser aplicado. Em substratos com menor capacidade de retenção de água (casca de arroz carbonizada, areia, moinha de carvão, etc.), a irrigação deve ser mais freqüente do que naqueles de maior capacidade de retenção (terra de subsolo, composto orgânico, húmus, fibras de coco, etc.). 
Em mudas de Pinus spp, produzidas em recipientes de pequenas dimensões, as irrigações devem ser realizadas com alta freqüência, mesmo com prejuízos àrustificação dos tecidos das mudas. Devido ao pequeno volume de substrato existente, o processo de lixiviação ocorre rapidamente, carregando consigo os íons fertilizantes. Como conseqüência, as irrigações devem conter nutrientes para fornecer novos suprimentos nutricionais às mudas (Carneiro, 1995).

Exceto os períodos de germinação das sementes e enraizamento das estacas, uma irrigação freqüente de baixa intensidade não é tão eficaz quanto uma aplicação prolongada e em intervalos mais longos. Irrigações freqüentes molham somente alguns centímetros da camada superficial do substrato, resultando em maior perda por evaporação, principalmente em dias quentes e secos. A maior eficiência do uso da água ocorre quando a mesma é aplicada pela manhã e a perda por evaporação ainda é pequena. Além disso, as irrigações feitas pela manhã, evitam que o substrato apresente umidade excessiva durante o período noturno, reduzindo os riscos de doenças nas mudas. A irrigação durante os horários mais quentes do dia é prejudicial quando a água utilizada no viveiro apresenta elevadas concentrações de cálcio e magnésio. Nessas condições, associada a uma elevada demanda atmosférica, poderá ocorrer a formação de um encrostamento de cálcio e carbonatos de magnésio na superfície do substrato, o que pode ser prejudicial ao desenvolvimento das mudas em função do aumento do potencial osmótico ou diminuição da capacidade de infiltração de água no substrato (Wendling \& Gatto, 2002).

Carneiro (1995) recomenda que após a semeadura, a camada superficial do substrato deve permanecer úmida para favorecer o processo germinativo. Por outro lado, deve-se evitar o excesso de umidade que favorece a lixiviação de nutrientes e o possível surgimento de doenças como "dampingoff", nas fases pré e pós-emergentes. $O$ excesso de umidade também cria condições desfavoráveis para a circulação do ar no substrato. A eficiência do 
sistema radicular é influenciada pela aeração, visto que a energia despendida no processo de crescimento é obtida pelas raízes por meio da respiração. Portanto, se a aeração for prejudicada por excesso de umidade, o desenvolvimento radicular também fica prejudicado. Com adequada aeração, as raízes tornam-se profusamente subdivididas, longas, tendo coloração clara e grande quantidade de pêlos absorventes.

\subsubsection{Manejo da irrigação na produção de mudas de cafeeiro em tubetes}

Numa primeira análise, verifica-se que os trabalhos realizados com mudas de cafeeiro em tubetes, contemplam em sua maioria, o estudo de tipos de substratos e doses de fertilizante. Pouco se tem feito quanto ao manejo da irrigação na produção de mudas de cafeeiro em tubetes.

Silva et al. (1991) verificaram um maior desenvolvimento das mudas de cafeeiro quando submetidas ao seguinte manejo da irrigação: irrigações diárias durante as fases de germinação e "palito de fósforo" até a emissão do segundo par de folhas, aplicando-se uma lâmina de 1,5 e 1,9 mm respectivamente; irrigações a cada quatro dias durante a fase compreendida entre o segundo e quarto pares de folhas e a fase posterior a quatro pares de folhas, aplicando uma lâmina média de 5,8 e 13,2 mm, respectivamente. Guimarães et al. (1998) recomendaram a aplicação de uma lâmina diária de $2,5 \mathrm{~mm}$ durante a germinação da semente até a fase denominada "orelha de onça". A partir da emissão da primeira folha definitiva até a retirada da muda do viveiro, os autores sugeriram a aplicação de uma lâmina diária de $4,5 \mathrm{~mm}$. Segundo Silva et al. (2000), o sistema de irrigação deve ser constituído de uma tubulação suspensa sobre os canteiros, utilizando-se microaspersores tipo bailarina (invertida ou não), com bocal de $104 \mathrm{~L} \mathrm{~h}^{1}$, espaçados de $4 \times 2 \mathrm{~m}$. Nessas condições haverá uma uniformidade de distribuição de água, que será aplicada a uma intensidade de $13 \mathrm{~mm} \mathrm{~h}^{-1}$. De acordo com esses autores, a irrigação deve ser dividida em duas frações diárias, de preferência nas horas de 
temperaturas mais amenas (manhã e a tarde), funcionando o sistema por um período de 3 minutos. Com esse manejo seria aplicada uma lâmina diária de $1,3 \mathrm{~mm}$.

\subsection{Uso de polímeros hidroabsorventes na agricultura}

Segundo Kämpf (1999), condicionador é qualquer produto adicionado ao solo com o objetivo de melhorar suas propriedades. Dentre esses produtos se encontram os polímeros hidroabsorventes. Os primeiros polímeros sintéticos foram introduzidos no início dos anos 50, dentre os quais o Krilium $^{\circledR}$ (poliacrilonitrita hidrolisada) foi o mais conhecido. Devido à sua habilidade em absorver centenas de vezes seu próprio peso em água, poliacrilamidas e polimetacrilatos (também conhecidos como polímeros absorventes, polímeros super absorventes ou hidrogéis) foram testados na agricultura, horticultura e paisagismo no início dos anos 60. O interesse desapareceu quando experimentos provaram que os mesmos eram fitotóxicos, devido à presença de resíduos do monômero acrilamida. Muito embora, avanços na tecnologia de fabricação, diminuíssem a concentração do monômero abaixo do nível de toxidez, a literatura científica mostrou pouco sucesso no uso desses polímeros em relação ao aumento da qualidade e rendimento das colheitas. As pesquisas foram retomadas no início dos anos 80, com o aparecimento de uma nova geração de polímeros e co-polímeros das famílias da propenamida e propenamida-propenoato (TerraCottem, s.d.).

Existem três tipos de polímeros: os naturais (borracha, couro e algodão), naturais modificados (semi-sintéticos) e os sintéticos (Molyneux, citado por Seybold, 1994).

Os polímeros mais utilizados são os de propenamida (originalmente denominados poliacrilamida ou PAM) e os co-polímeros propenamidapropenoato (originalmente conhecidos como poliacrilamida-acrilato ou PAA), usados como floculante principalmente em fraldas e outros artigos sanitários e 
para depósitos de líquidos químicos residuais. Quimicamente, os polímeros são constituídos de uma longa cadeia de unidades estruturais repetidas chamadas monômeros. A polimerização ocorre quando duas ou mais pequenas moléculas se combinam para formar as moléculas maiores, ou cadeias de polímeros. Unidas por ligações covalentes, as moléculas individuais são atraídas e ligadas entre si por fortes ligações (pontes de hidrogênio). Em contato com a água, essas ligações são enfraquecidas e ocorre a expansão. Muito embora exteriormente, um hidrogel possa parecer semelhante a outro, a sua constituição química e estrutura física podem ser diferentes e isso afetará a maneira de sua absorção, retenção e liberação de seu conteúdo. Quanto a habilidade de retenção de água, existem três grupos distintos de polímeros absorventes: no grupo I, a água fica irreversivelmente confinada por uma forte ligação $\mathrm{H}-\mathrm{H}$ (hidrogênio-hidrogênio), permanecendo portanto $100 \%$ dentro do hidrogel, ou seja, nenhuma água é liberada; no grupo II, os polímeros têm capacidade de absorver enorme quantidade de água, mas uma fraca ligação física evita a permanência da água no hidrogel por longos períodos, sendo perdida dentro de poucos dias; no grupo III, a água é retida por fracas ligações de hidrogênio, de modo que o hidrogel absorve e libera a água por longos períodos de tempo (TerraCottem, s.d.).

\subsubsection{Efeitos dos polímeros hidroabsorventes no sistema solo-planta}

A literatura apresenta vários trabalhos que mostram os benefícios dos polímeros hidroabsorventes nas propriedades físico-hídricas dos meios porosos.

Prevedello \& Balena (2000) estudaram os efeitos dos polímeros hidroabsorventes nas propriedades físicas e hidráulicas de dois tipos de solos. Verificaram que o aumento na dose do polímero reduziu os valores da condutividade hidráulica do meio saturado em ambos os materiais. Al-Darby (1996) encontrou resultados semelhantes com a adição do polímero em um 
solo arenoso. Segundo esse autor, a redução da condutividade hidráulica se deve àredução do raio médio dos poros devido à expansão do polímero. Nesse trabalho, também foi verificado um aumento na disponibilidade de água em função das doses crescentes do polímero. Hedrick \& Mowry (1952) observaram que quando poliacrilonitrila hidrolisada foi aplicada a taxas de $0,01 \%$ a $0,1 \%$, em um solo desestruturado, o número de agregados estáveis aumentou. $\bigcirc$ escoamento superficial foi reduzido devido ao aumento da infiltração. Houve um aumento na disponibilidade de água para as plantas e a taxa de evaporação na superfície do solo foi reduzida. Devido ao aumento da estabilidade de agregados em água nos solos tratados, houve uma melhoria na aeração. AlHarbi et al. (1999) estudaram o efeito de polímeros hidrofílicos em mistura com solo arenoso no crescimento de plantas de pepino, em vários experimentos sucessivos no mesmo recipiente, durante um período de 2 anos. Verificaram que a densidade inicial da mistura diminuiu em função de doses crescentes do polímero. Ao final do último experimento, constataram que a densidade aumentou em todos os tratamentos e a capacidade de retenção de água diminuiu, sendo observada uma redução mais evidente nos tratamentos que utilizaram as maiores doses do polímero. Esses fatos foram atribuídos à perda da efetividade do polímero com o tempo.

Por outro lado, quando esses polímeros são incorporados aos substratos hortícolas, os efeitos do hidrogel têm provocado resultados variados nas características de retenção de água, no consumo de água e na resposta das plantas (Fonteno \& Bilderback, 1993). Segundo esses autores, os tipos químicos de polímeros mais utilizados em mistura com substratos são aqueles derivados do amido, os de poliacrilamida e os co-polímeros de propenoatopropenamida. Para Wang \& Gregg (1990), hidrogéis derivados do amido apresentam muitos grupos de hidroxilas, os quais permitem que moléculas de água sejam adsorvidas ao hidrogel, resultando numa rápida absorção e expansão desses materiais. Polímeros de poliacrilamida com elevado grau de ligações cruzadas, apresentam baixa capacidade de retenção de água, embora 
sejam resistentes aos danos causados por vários sais. Já os co-polímeros de propenoato-propenamida apresentam elevada capacidade de absorção em água destilada, entretanto, são fisicamente instáveis na presença de sais devido à poucas e fracas ligações cruzadas.

O comportamento dos três tipos de hidrogéis pode variar de acordo com a quantidade de insumos normalmente utilizados nos cultivos intensivos em casa-de-vegetação e em viveiros de produção de mudas. Trabalhos têm atribuído essa variabilidade ao efeito dos sais presentes na solução do substrato. Foster \& Keever, citados por Fonteno \& Bilderback (1993) verificaram que elevadas concentrações de íons livres na solução (principalmente cátions bivalentes), reduziram a capacidade de polímeros sintéticos e a base de amido em absorver água. Bowman et al. (1990) observaram que a hidratação de três polímeros comerciais de poliacrilamida, na presença de cátions bivalentes $\left(\mathrm{Ca}^{+2}\right.$ e $\left.\mathrm{Mg}^{+2}\right)$ e cátions monovalentes $\left(\mathrm{K}^{+}\right.$e $\left.\mathrm{NH}_{4}{ }^{+}\right)$, foi reduzida a aproximadamente $10 \%$ e $20 \%$ do seu valor máximo, respectivamente. Verificaram também que ânions, independente da valência, e a uréia (solução de 2 a $20 \mathrm{mM}$ ) não afetaram a hidratação dos polímeros.

Quando incorporado aos substratos hortícolas, os efeitos do hidrogel nas propriedades físicas também têm sido variáveis. Ingram \& Yeager, citados por Fonteno \& Bilderback (1993), não encontraram efeito da adição de polímeros no volume de água retido àtensão de $10 \mathrm{kPa}$. Bowman et al. (1990) verificaram que não houve efeito nas propriedades físicas, mesmo quando da adição de duas vezes a dosagem recomendada do polímero. Entretanto, Wang \& Gregg (1990) observaram que os substratos tratados com um polímero de poliacrilamida, na ausência de micronutrientes, alcançaram o máximo de retenção de água após seis irrigações, enquanto que naqueles onde houve a adição de micronutrientes, o máximo da retenção ocorreu após 10 irrigações. A quantidade de água retida nos vasos diminuiu após repetidas fertilizações. $\mathrm{O}$ volume do substrato no interior dos vasos aumentou com níveis crescentes do 
polímero, embora nos vasos onde os micronutrientes foram incorporados, esse volume tenha diminuído.

Resultados baseados no desenvolvimento das culturas, quando da utilização de polímeros hidroabsorventes, também não são conclusivos. Gehring \& Lewis (1980) estudaram o efeito de doses crescentes de um copolímero de propenoato-propenamida adicionado em substrato àbase de turfa, em recipientes de vários tamanhos, no tempo de murchamento de plantas ornamentais. Verificaram que elevadas taxas do hidrogel incorporado ao substrato foram efetivas no aumento do tempo de murchamento, em todos os tamanhos de recipiente. Danneels \& van Cotthem (1994) observaram ganhos significativos na biomassa e aumento na eficiência do uso da água, quando plantas como pimentão, feijão e milho foram cultivadas em uma mistura contendo areia e doses crescentes de condicionador de solo. Chatzoudis \& Valkanas (1995) verificaram que a combinação de polímeros e fertilizante de liberação controlada promoveu um aumento significativo de matéria seca em plantas de alface. Em outro experimento, constataram que plantas cultivadas em solo contendo polímero, sob freqüência de irrigação variando de 4 a 24 dias, não apresentaram diferenças no peso da matéria seca, na absorção de nutrientes e no aspecto qualitativo. Rigas et al. (1999) estudaram o efeito de polímeros condicionadores de solo no crescimento de plantas de girassol e observaram melhorias expressivas nos parâmetros de solo e da planta tais como: diminuição no tempo de emergência das sementes (32\% quando comparado ao tratamento sem adição do condicionador), aumento no crescimento das plantas de $50 \%$, aumento no tempo de murchamento das plantas de 367\%, aumento na retenção de água do substrato ao nível da capacidade de campo de $214 \%$ e aumento na disponibilidade de água de $244 \%$.

Por outro lado, alguns trabalhos têm mostrado efeitos não significativos no desenvolvimento de culturas com a adição de polímeros. Austin \& Bondari (1992) verificaram, após um período de dois anos, que a adição de polímero 
tanto em turfa como em casca de pinus ou solo, não teve efeito no crescimento, produtividade e peso das bagas de plantas de "blueberry". Em outro experimento (11 anos de avaliações), observaram que não houve efeito da adição de polímero em turfa, tanto na produção como nas variáveis vegetativas diâmetro de copa, comprimento do caule, número de folhas e comprimento dos internódios. Taylor \& Halfacre (1986) constataram a interação entre polímero e fertilizante de liberação controlada no peso seco de plantas de ligustro. Verificaram que o peso seco das plantas cultivadas em meio sem polímero aumentou com o aumento da fertilização. Entretanto, as plantas que se desenvolveram em meio contendo polímero produziram menos massa seca com o aumento da taxa de fertilização. Lamont \& O'Connell (1987) verificaram que um hidrogel a base de amido, na dosagem de $1 \mathrm{~kg} \mathrm{~m}^{-3}$ e incorporado a uma mistura contendo turfa, areia e casca de arroz, não teve efeito na produção de biomassa e no tempo de murchamento de plantas de petúnia. Resultados similares foram encontrados em plantas de malmequer, quando da adição de um co-polímero de acrilamida na dosagem de $0,5 \mathrm{~kg} \mathrm{~m}^{-3}$. 


\section{MATERIAL E MÉTODOS}

\subsection{Local do experimento}

O experimento foi instalado na área experimental do Departamento de Engenharia Rural da Escola Superior de Agricultura "Luiz de Queiroz", situada no município de Piracicaba - SP, cujas coordenadas geográficas são: latitude $22^{\circ} 42^{\prime} \mathrm{S}$, longitude $47^{\circ} 38^{\prime} \mathrm{W}$ e altitude de $520 \mathrm{~m}$.

Para a condução do experimento, foi construída uma casa de vegetação com as seguintes dimensões: $22,5 \mathrm{~m}$ de comprimento (9 segmentos de 2,5 m), 6,4 m de largura e 3,0 m de pé direito. Em cada segmento, foram colocadas barras metálicas transversais para sustentação dos trilhos utilizados para o deslocamento de uma barra de irrigação. Foram instaladas duas janelas frontais para permitir a circulação do ar e melhorar as condições internas de temperatura. Cortinas reguláveis foram colocadas nas laterais da casa de vegetação para evitar a entrada de água da chuva e a incidência de ventos frios no período do inverno.

A casa de vegetação foi planejada de modo a simular as condições de um viveiro de podução de mudas de cafeeiro. Foi coberta por um filme de polietileno transparente e por um sombrite de $50 \%$ de luminosidade. Esse mesmo sombrite foi utilizado para revestimento lateral da casa de vegetação, com a finalidade de evitar a entrada de insetos. 


\subsection{Delineamento experimental}

Adotou-se o delineamento experimental de blocos casualizados em esquema de parcelas sub-subdivididas com 4 repetições (blocos). As parcelas foram constituídas por diferentes lâminas de irrigação, sendo 4 níveis baseados na evaporação (EV) de um minitanque automatizado (50, 75, 100 e 125\% da EV) e um nível adicional, denominado controle. Nesse tratamento, aplicou-se uma lâmina diária de 2,5 mm durante o estádio de "orelha de onça" até a emissão do segundo par de folhas, aumentando para $4 \mathrm{~mm}$ diários, a partir dessa fase até o final do experimento. Detalhes da automação do minitanque são apresentados no Anexo A.

As parcelas foram representadas por 20 bancadas construídas em madeira, apresentando dimensões de 1,8 $\mathrm{m}$ de comprimento, 1,0 $\mathrm{m}$ de largura e instaladas a uma altura de 1,2 $\mathrm{m}$ da superfície do solo. As mesmas foram dispostas em duas fileiras iguais espaçadas entre si de 1,4 m, e dentro de cada fileira, distanciadas de 0,8 m. Cada parcela foi dividida em duas subparcelas, representadas por tubetes de diferentes volumes $\left(60\right.$ e $\left.120 \mathrm{~cm}^{3}\right)$. Esses tubetes foram distribuídos sobre uma tela metálica com malha de $4 \times 4 \mathrm{~cm}$, soldada em um quadro feito em cantoneira. Para manter a mesma densidade de plantas, os tubetes menores $\left(60 \mathrm{~cm}^{3}\right)$ foram apoiados dentro dos maiores com o auxílio de um anel de PVC de $2 \mathrm{~mm}$ de espessura.

Finalmente, nas sub-subparcelas, foram avaliadas diferentes doses do condicionador TerraCottem ${ }^{\circledR}\left(0 ; 2,5 ; 5 ; 7,5\right.$ e $10 \mathrm{~kg} \mathrm{~m}^{-3}$ de substrato). Para cada dose do condicionador, foram utilizadas duas fileiras de nove plantas. Em cada fileira, as cinco plantas centrais foram utilizadas para as avaliações das variáveis vegetativas (plantas úteis). Considerando cinco doses do condicionador e dois tamanhos de tubetes, cada parcela foi constituída por 100 plantas úteis. Nas extremidades das bancadas e entre as subparcelas foram distribuídas mais 170 plantas, as quais serviram como bordadura. A Figura 1 ilustra o croqui da área experimental. 

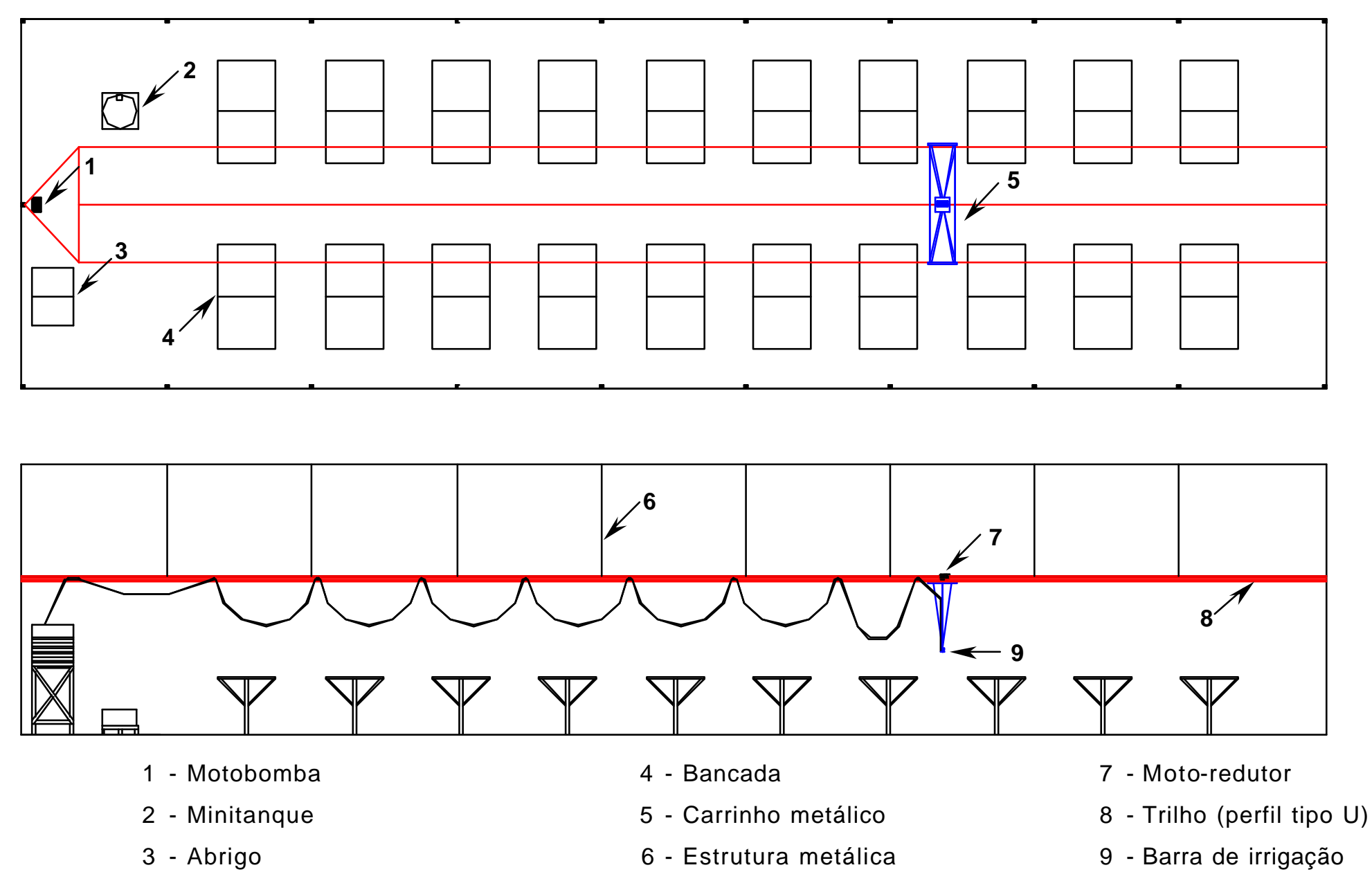

Figura 1 - Croqui da área experimental. 


\subsection{Semeadura}

Para a realização do experimento, utilizou-se o método de semeadura indireta ou repicagem. Geralmente a semeadura é feita em germinadores de areia, e posteriormente, quando as plântulas atingem o estádio "palito de fósforo" ou "orelha de onça", é feito o transplantio para os recipientes (saquinhos ou tubetes). Foram utilizadas sementes da cultivar Catuaí Vermelho (Linhagem IAC H2077-2-5-99), colhidas na safra 2000/2001 e armazenadas em câmara fria para manutenção do poder germinativo. Algumas características dessa cultivar são o porte baixo, internódios curtos, ramificação secundária abundante, frutos vermelhos de maturação média a tardia, sementes de tamanho médio com peneira em torno de 16 e suscetível à ferrugem. Essa cultivar é indicada para plantios adensados, superadensados ou em renque.

Por ocasião da semeadura (04/02/02), as sementes foram tratadas com o fungicida Pencycuron $\left(0,75 \mathrm{~g}\right.$ i.a $\mathrm{kg}^{-1}$ sementes) para evitar a infeção por fungos de solo. Após o tratamento, essas foram distribuídas sobre a superfície do germinador numa proporção de $1 \mathrm{~kg} \mathrm{~m}^{-2}$ e em seguida cobertas com $2 \mathrm{~cm}$ de areia. $\mathrm{O}$ germinador foi coberto com um sombrite (80\%), com o objetivo de reduzir as perdas de água por evaporação e proporcionar um aumento de temperatura na sua superfície. Essas condições são desejáveis, pois aceleram o processo de germinação, que na cultura do cafeeiro é naturalmente lento (50 a 60 dias). Durante a fase de germinação, foram efetuadas regas diárias com 0 intuito de manter úmido o leito da sementeira.

\subsection{Componentes do substrato}

Para o desenvolvimento das mudas utilizou-se uma mistura composta de um substrato orgânico comercial, um fertilizante de liberação controlada e um condicionador. As características de cada componente da mistura são descritas a seguir. 


\subsubsection{Substrato orgânico}

A base da mistura foi composta pelo substrato orgânico comercial Plantmax-Café ${ }^{\circledR}$. Trata-se de um produto compostado e estabilizado utilizandose cascas processadas, vermiculita expandida, perlita expandida e turfa processada. Segundo o fabricante, o produto apresenta algumas características como umidade em torno de 50 a 60\% (base peso), capacidade de retenção de água de pelo menos $150 \%$, condutividade elétrica (1:2, base volume) variando de 0,5 a $1,3 \mathrm{dS} \mathrm{m}^{-1}$ e pH na faixa de 5,5 a 6,2. A Tabela 1 apresenta a análise laboratorial do substrato orgânico.

\subsubsection{Fertilizante de liberação controlada}

A adubação do substrato foi feita com o fertilizante de liberação controlada Sierra 15-10-10 + micronutrientes, na dosagem de 8,2 $\mathrm{kg} \mathrm{m}^{-3}$ de substrato. Esse fertilizante é composto de grânulos recobertos por uma resina orgânica, que controla a liberação dos nutrientes durante o período de longevidade do produto, de acordo com a temperatura do meio e do substrato. Após sua aplicação, o vapor d'água presente no substrato penetra na resina e dissolve os nutrientes no seu interior, os quais vão sendo liberados no substrato de forma gradual. $O$ fertilizante utilizado apresenta um período de liberação de 5 a 6 meses, quando a temperatura do substrato se encontra em torno de 21 ${ }^{\circ} \mathrm{C}$. Temperaturas inferiores e superiores podem retardar ou acelerar o processo de liberação. Foi enviada uma amostra do fertilizante para análise da composição química e os resultados podem ser vistos na Tabela 2. 
Tabela 1. Caracterização física e química do substrato orgânico ${ }^{1}$

\begin{tabular}{|c|c|}
\hline Determinações & Unidade \\
\hline $\mathrm{pH} \mathrm{em} \mathrm{CaCl}_{2} 0,01 \mathrm{M}$ & 4,7 \\
\hline Densidade & $0,51 \mathrm{~g} \mathrm{~cm}^{-3}$ \\
\hline Umidade (base úmida) & $49,77 \%$ \\
\hline Matéria orgânica total (combustão) & $59,07 \%$ \\
\hline Matéria orgânica compostável & $57,14 \%$ \\
\hline Matéria orgânica resistente àcompostagem & $1,93 \%$ \\
\hline Carbono total (orgânico e mineral) & $32,83 \%$ \\
\hline Carbono orgânico & $31,75 \%$ \\
\hline Resíduo mineral total & $40,93 \%$ \\
\hline Resíduo mineral insolúvel & $25,88 \%$ \\
\hline Resíduo mineral solúvel & $15,05 \%$ \\
\hline Nitrogênio total & $0,88 \%$ \\
\hline Fósforo $\left(\mathrm{P}_{2} \mathrm{O}_{5}\right)$ total & $0,40 \%$ \\
\hline Potássio $\left(\mathrm{K}_{2} \mathrm{O}\right)$ total & $0,38 \%$ \\
\hline Cálcio $(\mathrm{Ca})$ total & $1,08 \%$ \\
\hline Magnésio $(\mathrm{Mg})$ total & $1,79 \%$ \\
\hline Enxofre (S) total & $0,30 \%$ \\
\hline Relação C/N (C total e N total) & $38 / 1$ \\
\hline Relação C/N (C orgânico e N total) & $36 / 1$ \\
\hline Cobre $(\mathrm{Cu})$ total & $28 \mathrm{mg} \mathrm{kg}^{-1}$ \\
\hline Manganês (Mn) total & $229 \mathrm{mg} \mathrm{kg}^{-1}$ \\
\hline Zinco (Zn) total & $52 \mathrm{mg} \mathrm{kg}^{-1}$ \\
\hline Ferro $(\mathrm{Fe})$ total & $18260 \mathrm{mg} \mathrm{kg}^{-1}$ \\
\hline Boro (B) total & $8 \mathrm{mg} \mathrm{kg}^{-1}$ \\
\hline Sódio $(\mathrm{Na})$ total & $358 \mathrm{mg} \mathrm{kg}^{-1}$ \\
\hline
\end{tabular}

${ }^{1}$ Análise realizada no laboratório de Solos e Nutrição de Plantas - ESALQ/USP. 
Tabela 2. Composição química do fertilizante de liberação controlada

\begin{tabular}{lcc}
\hline Elemento & Garantia do fabricante & Análise do laboratório' $^{1}$ \\
\hline $\mathrm{N}$ (total) & $15,0 \%$ & $14,53 \%$ \\
$\mathrm{~N}$ (amoniacal) & $8,3 \%$ & $7,85 \%$ \\
$\mathrm{~N}$ (nítrico) & $6,7 \%$ & $6,47 \%$ \\
$\mathrm{P}$ (total) & $10,0 \%$ & $11,20 \%$ \\
$\mathrm{~K} 20$ & $10,0 \%$ & $14,20 \%$ \\
$\mathrm{Ca}$ & $3,5 \%$ & $3,13 \%$ \\
$\mathrm{Mg}$ & $1,5 \%$ & $1,88 \%$ \\
$\mathrm{~S}$ & $3,0 \%$ & $4,96 \%$ \\
$\mathrm{Fe}$ & $0,5 \%$ & $0,38 \%$ \\
$\mathrm{Mn}$ & $0,1 \%$ & $0,07 \%$ \\
$\mathrm{Cu}$ & $0,05 \%$ & $0,03 \%$ \\
$\mathrm{Zn}$ & $0,05 \%$ & $0,03 \%$ \\
$\mathrm{~B}$ & $0,02 \%$ & $0,03 \%$ \\
\hline
\end{tabular}

${ }^{1}$ Análise realizada no laboratório de Solos e Nutrição de Plantas - ESALQ/USP.

\subsubsection{Condicionador}

Por definição, condicionador é qualquer produto adicionado ao solo ou ao substrato, com o objetivo de melhorar suas propriedades. Neste trabalho utilizou-se o condicionador TerraCottem ${ }^{\circledR}$, constituído por uma mistura de 23 componentes de quatro diferentes grupos: polímeros hidroabsorventes, fertilizantes, estimuladores de crescimento e um veículo (Tabela 3). 
Tabela 3. Características químicas e físicas do TerraCottem ${ }^{\circledR}$

\begin{tabular}{|c|c|}
\hline Componentes $^{1}$ & Unidade \\
\hline Fração polímero & $39,50 \%$ \\
\hline Fração fertilizante & $10,50 \%$ \\
\hline Nitrogênio (N) & $4,80 \%$ \\
\hline Fósforo $\left(\mathrm{P}_{2} \mathrm{O}_{5}\right)$ & $0,90 \%$ \\
\hline Potássio $\left(\mathrm{K}_{2} \mathrm{O}\right)$ & $2,90 \%$ \\
\hline Magnésio (MgO) & $0,18 \%$ \\
\hline Boro (B) & $0,002 \%$ \\
\hline Cobre (Cu) & $0,005 \%$ \\
\hline Ferro $(\mathrm{Fe})$ & $0,015 \%$ \\
\hline Manganês (Mn) & $0,008 \%$ \\
\hline Molibdênio (Mo) & $0,002 \%$ \\
\hline Zinco (Zn) & $0,002 \%$ \\
\hline Estimuladores de crescimento & $0,25 \%$ \\
\hline Veículo & $49,75 \%$ \\
\hline Sílica & $49,45 \%$ \\
\hline Alumínio & $0,10 \%$ \\
\hline Potássio e Sódio $\left(\mathrm{K}_{2} \mathrm{O}\right.$ e $\left.\mathrm{Na}_{2} \mathrm{O}\right)$ & $0,05 \%$ \\
\hline Cálcio e Magnésio ( $\mathrm{CaO}$ e MgO) & $0,02 \%$ \\
\hline Granulometria & $\leq 4 \mathrm{~mm}$ \\
\hline Densidade & $1,15 \mathrm{~kg} \mathrm{~m}^{-3}$ \\
\hline $\mathrm{pH}$ & 6,80 \\
\hline Solubilidade em água & $\begin{array}{c}\text { Praticamente } \\
\text { insolúvel }\end{array}$ \\
\hline
\end{tabular}

${ }^{1}$ Catálogo do fabricante. 


\subsection{Preparo do substrato e enchimento dos tubetes}

O preparo do substrato iniciou-se no dia 22/03/02, ou seja, 46 dias após a semeadura (DAS). Nesta época as plântulas encontravam-se no estádio de "palito de fósforo", prontas para serem repicadas para os tubetes.

A mistura foi homogeneizada com o auxílio de uma betoneira (rotação de $30 \mathrm{rpm}$ ) por um período de 35 minutos. O fabricante do substrato recomenda no ato da mistura, adicionar 5 litros de água para cada $25 \mathrm{~kg}$ de substrato (1 saco). Entretanto, testes preliminares demonstraram que a adição de água ao substrato favoreceu a formação de grumos. Esses poderiam comprometer a uniformidade da mistura, em virtude da elevada higroscopicidade dos polímeros hidroabsorventes presentes no condicionador. Dessa forma, nos primeiros 25 minutos, foram misturados apenas o substrato orgânico em sua umidade natural (em torno de 50\%) e o condicionador. Nos últimos 10 minutos, foi adicionado o fertilizante de liberação controlada com dois objetivos: primeiro, assegurar uma boa distribuição do fertilizante àmistura e segundo, evitar que o atrito dos péletis do fertilizante com as paredes da betoneira, causasse danos à resina responsável pela liberação controlada dos nutrientes.

Após a mistura dos substratos, correspondentes aos diferentes tratamentos, procedeu-se o enchimento manual dos tubetes. Os mesmos foram dispostos lado a lado em uma bandeja auxiliar e umedecidos com o auxílio de um regador. Em seguida foi feita a distribuição da mistura e compactação com os dedos. Essa compactação foi feita para evitar perda de substrato pelo orifício inferior do tubete.

\subsection{Repicagem}

O processo de repicagem iniciou-se em 26/03/02 quando as plântulas se encontravam no estádio "palito de fósforo", estendendo-se por um período de 4 dias (Figura 2). 


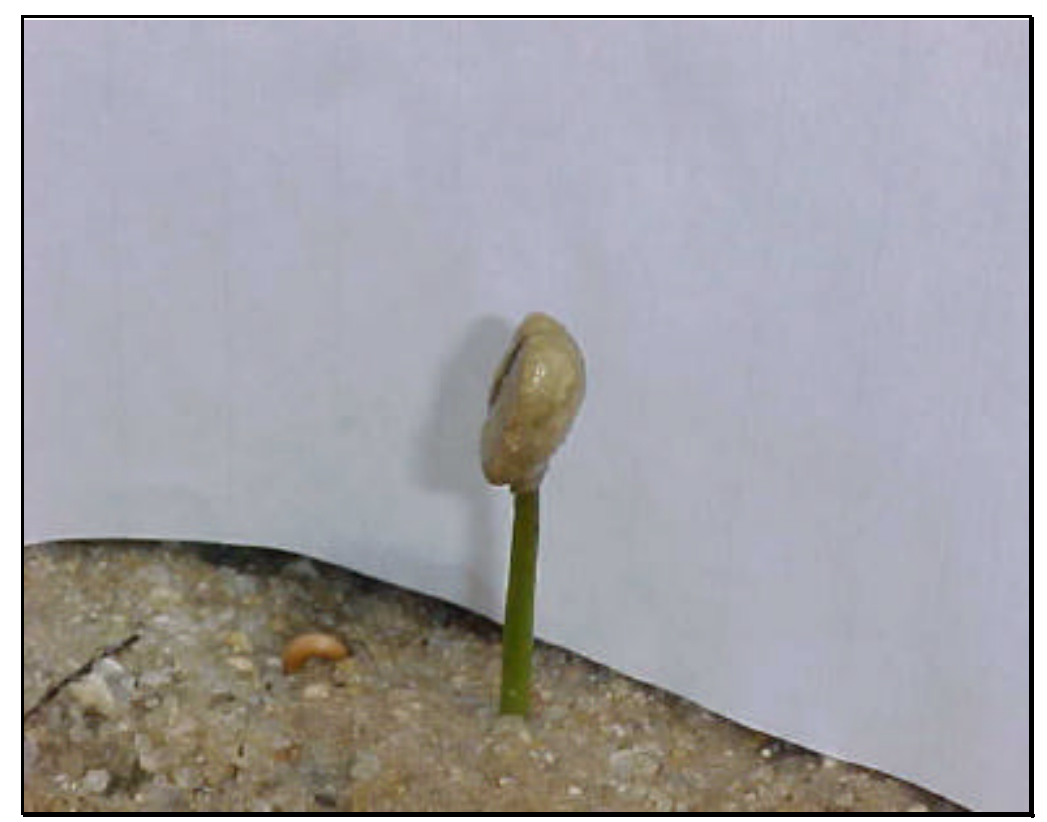

Figura 2 - Muda de cafeeiro no estádio "palito de fósforo".

Foram repicadas 270 plântulas por bancada, num total de 5400 plântulas. Após retiradas do germinador, as plântulas selecionadas foram submetidas a uma lavagem para retirada do excesso de areia no sistema radicular. Posteriormente, com o auxílio de uma tesoura previamente desinfetada em álcool, procedeu-se ao corte da raiz principal a pelo menos 5 $\mathrm{cm}$ do colo da plântula e um pequeno toalete das raízes laterais. Este procedimento foi feito para adequar o sistema radicular æ̀s dimensões dos tubetes.

\subsection{Manejo da irrigação}

No manejo da irrigação foi utilizado um sistema automatizado constituído de uma barra transversal móvel, semelhante àquelas utilizadas em pulverização (Anexo B). 
Durante o período de repicagem, o sistema de irrigação foi acionado para aplicação de uma lâmina de $4 \mathrm{~mm} \mathrm{dia}^{-1}$, com o objetivo de umedecer 0 substrato e facilitar o transplante. Essa lâmina também foi aplicada nos dois dias seguintes a término da repicagem. A partir do dia 01/04/02, iniciou-se a irrigação de pegamento das plântulas aplicando-se uma lâmina diária equivalente a $100 \%$ da evaporação do minitanque. Essa fase de pegamento estendeu-se até o dia 23/04/02. No dia seguinte, realizourse um teste visando quantificar a lâmina necessária para elevar a umidade do substrato até o momento em que houvesse drenagem, promovendo assim, uma uniformização da umidade em todos os tubetes. Para isso, utilizaram-se 20 tubetes controle de $120 \mathrm{~cm}^{-3}$ (1 por bancada) os quais receberam água com o auxílio de uma seringa. A lâmina média obtida com esse teste foi de $12,8 \mathrm{~mm}$, a qual foi dividida em 5 parcelas iguais e aplicada ao longo do dia. $O$ parcelamento foi adotado para evitar o escoamento superficial devido à elevada intensidade de aplicação do sistema de irrigação. Esse processo de uniformização da umidade caracterizou o início do experimento.

A partir do dia 25/04/02, iniciou-se a diferenciação das lâminas de irrigação baseadas na evaporação do minitanque além da aplicação da lâmina controle. A irrigação foi dividida em duas aplicações, sendo metade da lâmina aplicada pela manhã $(8: 00 \mathrm{~h})$ e a outra metade æ̀ 12:00 $\mathrm{h}$ (horário que antecedeu o pico da radiação global medida no interior da casa de vegetação). A diferenciação das lâminas de irrigação estendeu-se até o dia 25/08/02, caracterizando o final do experimento.

Periodicamente, foram coletadas amostras da água de irrigação para a determinação do $\mathrm{pH}$ e da condutividade elétrica.

\subsection{Eficiência da irrigação}

Durante o período experimental, foram pesados diariamente 30 tubetes (15 de cada tamanho) para a determinação da eficiência da irrigação. A 
eficiência da irrigação foi definida como sendo a relação entre a lâmina de água armazenada no interior do tubete e a lâmina aplicada definida com base na evaporação do minitanque. Considerando as características do sistema e as condições locais no momento das irrigações (ausência de vazamentos e vento), foram desprezadas as perdas por condução e deriva. Assim considerou-se a lâmina aplicada como sendo aquela que atingiu o dossel das plantas.

Para a determinação da eficiência da irrigação, os tubetes foram pesados em balança de precisão $(0,01 \mathrm{~g})$ e em seguida irrigados com a respectiva lâmina, conforme tratamento monitorado no dia. Posteriormente, com o auxílio de um papel absorvente, retirourse o excesso de água retido nas folhas da planta e na face externa dos tubetes, submetendo-os novamente à pesagem. A diferença entre o peso inicial e final foi atribuída àágua infiltrada no interior do tubete. Para evitar o efeito do desenvolvimento vegetativo devido aos diferentes tratamentos, foi utilizada diariamente uma bancada diferente para a determinação da eficiência da irrigação. Assim iniciou-se a semana (segundafeira) medindo a eficiência na bancada referente a $50 \% \mathrm{EV}$, terminando (sextafeira) na bancada equivalente ao tratamento controle. Ao final de uma semana foi possível percorrer 5 bancadas relativas a um bloco, e ao final de cada mês, todas as bancadas do experimento. A determinação da eficiência da irrigação para o tratamento de $50 \% \mathrm{EV}$, por exemplo, foi feita a cada 7 dias, e em bancadas diferentes (repetições do tratamento). Assim, durante uma semana, o valor da eficiência da irrigação nas 4 bancadas do tratamento foi estimado com base na medida feita em uma única bancada. Ao final do experimento as lâminas aplicadas foram corrigidas pela eficiência da irrigação.

\subsection{Elementos meteorológicos}

Durante a condução do experimento foram monitorados alguns elementos meteorológicos como temperatura e umidade relativa do ar, radiação global e saldo de radiação. Foram utilizados 4 psicrômetros aspirados de 
termopar (Marin et al., 2001), instalados a 1,5 m da superfície do solo. Os mesmos foram dispostos entre duas bancadas, sendo um para cada bloco.

A radiação global foi medida por um piranômetro de fotodiodo de silício (modelo LI200X, da marca LI-COR Inc. ), instalado no centro da estufa e a 3,5 $\mathrm{m}$ da superfície do solo. A medida do saldo de radiação foi realizada por um saldo radiômetro modelo Q7.1 (REBS), instalado sobre uma bancada central a 2,0 m da superfície do solo.

O registro das variáveis climáticas foi feito por um sistema de coleta de dados (modelo CR-10, marca Campbell Scientific), programado para efetuar as leituras a cada segundo e armazenar os dados médios a cada 20 minutos.

Com os dados armazenados foi possível estimar a evapotranspiração de referência pelo método de Penman-Monteith, após simplificação da equação original. Segundo Pereira et al. (2002), a evapotranspiração diária pode ser estimada por esse método utilizando-se a seguinte equação:

$\operatorname{ETP}=\frac{0,408 s\left(R_{n}-G\right)+\frac{\gamma 900 U_{2}\left(e_{s}-e_{a}\right)}{T+273}}{s+\gamma\left(1+0,34 U_{2}\right)}$

em que:

ETP - evapotranspiração de referência, $\mathrm{mm} \mathrm{d}^{-1}$;

$\mathrm{S}$ - declividade da curva de pressão de vapor, $\mathrm{kPa}^{\circ} \mathrm{C}^{-1}$;

$R_{n}$ - radiação líquida total diária, $M J m^{-2} d^{-1}$;

$\mathrm{G}$ - fluxo de calor no solo, $\mathrm{MJ} \mathrm{m}^{-2} \mathrm{~d}^{-1}$;

$\gamma$ - constante psicrométrica $\left(=0,063 \mathrm{kPa}^{\circ} \mathrm{C}^{-1}\right)$;

$\mathrm{U}_{2}$ - velocidade do vento a $2 \mathrm{~m}$ de altura, $\mathrm{m} \mathrm{s}^{-1}$;

$\mathrm{e}_{\mathrm{s}}$ - pressão de saturação de vapor, kPa;

$e_{a}$ - pressão parcial de vapor, kPa;

$\mathrm{T}$ - temperatura média do ar, ${ }^{\circ} \mathrm{C}$ 
Com base nas características locais e estruturais da área experimental, foram desprezados o fluxo de calor no solo e a velocidade do vento a $2 \mathrm{~m}$ de altura, simplificando a equação 1. Assim, na estimativa da evapotranspiração de referência pelo método de Penmam-Monteith, utilizou-se a seguinte equação:

$$
\mathrm{ETP}=\frac{0,408 s R_{n}}{s+\gamma}
$$

\subsection{Avaliações}

As avaliações realizadas durante a condução do experimento foram feitas conforme descrito anteriormente, para cada dose do condicionador, utilizando-se duas fileiras de nove plantas. Em cada fileira, as cinco plantas centrais foram utilizadas para as avaliações das variáveis vegetativas (plantas úteis). Na primeira fileira foram realizadas avaliações mensais das variáveis vegetativas altura, diâmetro do caule e área foliar. Para a determinação do diâmetro do caule utilizourse um paquímetro digital com precisão de 0,01 mm. A área foliar foi determinada através da metodologia proposta por Barros et al. (1973). Essa metodologia sugere a medição do maior comprimento e maior largura da folha e correção da área formada, pela multiplicação de um fator de forma equivalente a 0,667 .

A segunda fileira foi utilizada para determinação da matéria seca da parte aérea e do sistema radicular. Mensalmente, foi destruída uma planta de cada tratamento separando a parte aérea do sistema radicular. Esse material foi submetido à secagem, em estufa de ventilação forçada a $65{ }^{\circ} \mathrm{C}$, para determinação da matéria seca. $O$ substrato remanescente de cada repetição foi homogeneizado formando uma amostra composta. Essa amostra foi utilizada para a determinação da condutividade elétrica do extrato saturado.

Outras variáveis foram determinadas indiretamente como a relação entre as matérias secas da parte aérea e do sistema radicular, a área foliar 
específica, e a eficiência do uso da água. A área foliar específica é definida como sendo a relação entre a área do limbo foliar e o seu peso seco $\left(\mathrm{cm}^{2} \mathrm{~g}^{-1}\right)$. Alguns autores utilizam essa variável como indicativo da resistência da planta ao estresse hídrico. Quanto menor o valor dessa relação, mais resistente deve ser a planta ao estresse hídrico. Já a eficiência do uso da água é a relação entre a matéria seca produzida e o volume de água aplicado $\left(\mathrm{kg} \mathrm{m}^{-3}\right)$.

\subsection{Análises laboratoriais}

Paralelamente à condução do experimento foram feitas várias determinações no laboratório, tanto no substrato como no condicionador. No substrato foram feitas análises físicas e químicas como a curva característica de retenção de água, granulometria, condutividade hidráulica do material saturado e condutividade elétrica do extrato saturado. Já o condicionador foi submetido a diversos ensaios, segundo metodologia utilizada por Bowman et al. (1990).

\subsubsection{Análises do substrato}

\subsubsection{Curva característica de retenção de água}

Foi determinada uma curva de retenção para cada dose do condicionador. Cada curva foi constituída de 9 pontos $(0 ; 2 ; 4 ; 6,8 ; 10 ; 33 ; 80$; 300 e $1300 \mathrm{kPa}$ ) e 3 repetições por ponto. Até a tensão de 6,8 $\mathrm{kPa}$ utilizourse a mesa de tensão, sendo os demais pontos determinados no extrator de Richards. Os valores médios de cada ponto foram utilizados para o ajuste ao modelo de van Genuchten.

\subsubsection{Análise granulométrica}


Segundo Ansorena Miner (1994), não existe um padrão em relação à seqüência de peneiras que devem ser empregadas para a classificação dos substratos. A escolha é função do objetivo da análise granulométrica. Se o mesmo é estudar as propriedades físicas de aeração e retenção de água, devem-se selecionar peneiras com malhas compreendidas entre 0,1 a $1 \mathrm{~mm}$. Assim, foi utilizado um conjunto de peneiras com as seguintes malhas: $1 ; 0,59$; 0,5; 0,42; 0,25 e 0,105 mm. Foram pesadas cinco amostras (100 g) de substrato seco em estufa de ventilação forçada a $40{ }^{\circ} \mathrm{C}$. As peneiras, ordenadas por tamanho, foram colocadas sobre o aparelho vibratório o qual permaneceu em funcionamento durante $10 \mathrm{~min}$. Ao final desse tempo, foram pesados o conteúdo de cada peneira e o substrato remanescente no recipiente coletor. De acordo com esse método, a soma de todas as frações não deve ser inferior a $98 \%$ do peso inicial. A diferença deve ser incorporada àfração mais fina.

\subsubsection{Condutividade hidráulica do substrato saturado}

O método do permeâmetro de carga constante foi utilizado para a determinação da condutividade hidráulica do substrato saturado. O método foi aplicado de acordo com os passos sugeridos por Libardi (2000). Segundo esse autor, devem ser utilizados dois cilindros, um para acondicionar a amostra e outro para a formação da carga hidráulica. Durante a fase de saturação da amostra, observou-se a expansão do substrato devido àabso rção de água pelo condicionador. Essa absorção aumentou em função das crescentes doses do condicionador adicionadas ao substrato. Na maior dose, a expansão fez com que o substrato ocupasse mais de cilindro adicional, impossibilitando a formação da carga hidráulica. Para evitar esse problema, foi fixado um papel filtro entre os dois cilindros para posterior saturação das amostras. Dessa forma foi possível formar a carga hidráulica e a realização do ensaio (metodologia I). Após a determinação da condutividade hidráulica, as amostras foram 
submetidas à drenagem natural por 7 dias. Após esse período, retirou-se 0 papel filtro de cada amostra e iniciou-se um novo processo de saturação e determinação da condutividade hidráulica do material saturado (metodologia II). Assim, foi possível verificar o efeito do papel filtro na determinação dessa propriedade física.

\subsubsection{Condutividade elétrica do extrato saturado}

O substrato remanescente das plantas utilizadas na avaliação da matéria seca foi preparado para a determinação da condutividade elétrica. Em função da pequena quantidade de substrato recolhida nos tubetes, optou-se pela utilização do método inglês de diluição, adotado pela ADAS (Agricultural Development and Advisory Service) desde 1979. Esse método utiliza uma parte de substrato para 6 partes de água destilada (base volume). O inconveniente, comum a todos os métodos que empregam relações amplas de extração, está na possibilidade de se obter falsas leituras de salinidade pela solubilização de sais pouco solúveis, tais como o sulfato de cálcio (gesso). Esses sais não se encontram dissolvidos na solução aquosa dos meios de cultivo, mas sua solubilidade aumenta com o aumento das relações de extração. Mesmo assim, adotou-se o método inglês em função da sua praticidade, uma vez que o mesmo dispensa a etapa prévia de sução das amostras $(3 \mathrm{kPa})$, adotada no método holandês, o que simplifica as análises em suas aplicações de rotina.

No preparo do substrato para a determinação da condutividade elétrica, houve a necessidade de se retirar previamente, todos os péletis do fertilizante de liberação controlada presentes no substrato, sem danificá-los. A sua presença poderia mascarar os valores da condutividade elétrica, em função da possível liberação dos nutrientes presentes no seu interior para a solução do substrato. Após a retirada dos péletis, as amostras de substrato foram secas em estufa de ventilação forçada $\left(65^{\circ} \mathrm{C}\right)$ e peneiradas em peneira de malha 2 
$\mathrm{mm}$ para homogeneização, estando assim prontas para serem submetidas ao método de extração (Ansorena Miner, 1994).

Embora tenha sido utilizado o método de extração inglês para a determinação da condutividade elétrica, muitas tabelas apresentam os níveis adequados para as diferentes culturas com base no extrato de saturação. Assim, foi feita em laboratório uma curva de calibração da condutividade elétrica do extrato de saturação em função da condutividade elétrica obtida pela relação de extração 1:6. Essa curva foi obtida por meio da salinização do substrato com o próprio fertilizante de liberação controlada. Os péletis do fertilizante foram triturados e a resina foi separada do fertilizante por intermédio de um peneira de malha fina. Doses crescentes do fertilizante foram adicionadas em amostras de substrato puro, as quais foram utilizadas tanto para o preparo da pasta saturada como da suspensão. Com os valores de condutividade elétrica obtidos nas leituras do extrato de saturação e da suspensão, ajustou-se a seguinte equação de calibração:

$\mathrm{CE}_{\mathrm{es}}=1,2858+4,2088 \mathrm{CE}_{(1: 6)} \quad\left(R^{2}=0,9910\right)$

em que:

$\mathrm{CE}_{\mathrm{es}}$ - condutividade elétrica do extrato saturado, dS. $\mathrm{m}^{-1}$;

$C E_{(1: 6)}$ - condutividade elétrica da solução na razão de diluição 1:6 (base volume), dS. $\mathrm{m}^{-1}$

\subsubsection{Análises do condicionador}

\subsubsection{Absorção do condicionador}

Foi realizado um teste de absorção do condicionador em água destilada para verificar a sua hidratação em função do tempo. Para isso utilizou-se uma amostra de $1 \mathrm{~g}$ de condicionador com granulometria compreendida entre 1 e 2 
$\mathrm{mm}$. Essa amostra foi colocada em um bequer, o qual foi preenchido com 500 $\mathrm{cm}^{3}$ de água destilada $\left(\mathrm{CE}_{\mathrm{ad}}=0,0051 \mathrm{dS} \mathrm{\textrm {m } ^ { - 1 }}\right)$. O bequer foi coberto com um papel alumínio para evitar a evaporação da água. A intervalos de tempo, a amostra em fase de hidratação foi peneirada em peneira de malha fina e pesada em balança de precisão. Em seguida essa mesma amostra foi novamente colocada no bequer para continuar o processo de hidratação. Esse procedimento foi repetido várias vezes num período de $24 \mathrm{~h}$, possibilitando a elaboração da curva de absorção do condicionador em função do tempo.

\subsubsection{Absorção do condicionador em solução fertilizante}

O desenvolvimento das plantas ocorre em condições em que os sais fertilizantes encontram-se dissolvidos na solução dos meios de cultivo. Assim, foi realizado um teste para caracterizar a absorção do condicionador em soluções fertilizantes com diferentes valores de condutividade elétrica. Para isso, foram preparadas soluções cuja condutividade elétrica variou a intervalos crescentes até o limite superior de $9 \mathrm{dS}^{-1}$. Para o preparo das soluções utilizou-se o próprio fertilizante de liberação controlada, o qual foi previamente triturado e peneirado para separação da resina. Para cada ponto da curva foi utilizado $1 \mathrm{~g}$ de condicionador com granulometria compreendida entre 1 e $2 \mathrm{~mm}$ submetendo-o à hidratação em $500 \mathrm{~cm}^{3}$ de solução fertilizante por um período de $24 \mathrm{~h}$. Após esse período, as amostras foram recolhidas em uma peneira de malha fina e submetidas à pesagem. Assim, foi possível determinar a curva de absorção do condicionador em solução fertilizante.

\subsubsection{Reabsorção do condicionador}

No manejo de irrigação das culturas é possível que em determinada fase do ciclo, seja necessário a aplicação de uma lâmina de água adicional para lixiviar os sais em excesso, afim de proporcionar o desenvolvimento adequado 
das plantas. Assim, foi realizado um teste de reabsorção do condicionador em água destilada, após ter sido hidratado em solução fertilizante de elevada condutividade elétrica. Iniciourse 0 teste hidratando $1 \mathrm{~g}$ de condicionador (granulometria entre 1 e $2 \mathrm{~mm}$ ) numa solução fertilizante de condutividade elétrica de $9 \mathrm{dS} \mathrm{m}^{-1}$, por um período de $24 \mathrm{~h}$. No dia seguinte, determinourse a hidratação do condicionador na solução fertilizante, submetendo-o novamente à hidratação (24 h) em água destilada. Esse processo foi repetido por 3 dias, podendo assim verificar a rehidratação do condicionador em água destilada a partir da absorção inicial em solução fertilizante. 


\section{RESULTADOS E DISCUSSÃO}

\subsection{Propriedades físico-hídricas do substrato}

As propriedades físicas dos substratos utilizados para o cultivo são mais importantes que as químicas, pois uma vez que o substrato está no recipiente e a planta está crescendo nele, não é possível modificar suas características físicas básicas. Ao contrário das propriedades físicas, as químicas podem ser modificadas mediante técnicas de cultivo apropriadas, realizadas pelo agricultor.

Os resultados obtidos no teste para a determinação da granulometria do substrato se encontram na Tabela 4.

Tabela 4. Distribuição granulométrica do substrato

\begin{tabular}{cc}
\hline Diâmetro de partícula $(\mathrm{mm})$ & Porcentagem $^{1}$ \\
\hline$\geq 1$ & $41,82 \pm 4,31$ \\
{$[0,59-1)$} & $17,11 \pm 2,63$ \\
{$[0,50-0,59)$} & $3,26 \pm 0,76$ \\
{$[0,42-0,50)$} & $2,16 \pm 0,39$ \\
{$[0,25-0,42)$} & $10,43 \pm 1,01$ \\
{$[0,105-0,25)$} & $13,77 \pm 2,54$ \\
$\leq 0,105$ & $8,45 \pm 2,22$ \\
\hline
\end{tabular}

\footnotetext{
${ }^{1}$ Média de 5 repetições.
} 
Verificou-se que mais de $50 \%$ das partículas apresentaram diâmetros inferiores a $1 \mathrm{~mm}$. Esse resultado indica que 0 material apresenta características de retenção de água. Segundo Ansorena Miner (1994), para partículas de diâmetros compreendidos entre 1 e $10 \mathrm{~mm}$, tanto a porosidade quanto a retenção de água variam pouco com o tamanho da partícula. Entretanto, para partículas inferiores a $1 \mathrm{~mm}$, observa-se uma acentuada queda da porosidade e aumento na retenção de água. Por outro lado, nem todas as partículas inferiores a $1 \mathrm{~mm}$ têm a mesma influência nas propriedades físicas. Handreck (1983) estudou misturas baseadas em casca de pinus e concluiu que frações menores que $0,5 \mathrm{~mm}$, particularmente de 0,1 a $0,25 \mathrm{~mm}$, apresentam a máxima influência na porosidade de ar e na retenção de água. $O$ substrato utilizado no experimento apresentou $34,81 \%$ das partículas com diâmetro inferior a $0,5 \mathrm{~mm}$ e $13,77 \%$ das partículas com diâmetro entre 0,1 e 0,25 mm. Analisando apenas as classes de peneiras inferiores a $1 \mathrm{~mm}$, observou-se que o percentual de $13,77 \%$ das partículas compreendidas entre 0,1 e 0,25 mm foi inferior apenas ao valor de 17,11\%, para partículas de diâmetro entre 0,59 e 1 $\mathrm{mm}$. Embora inferior, esse valor de $13,77 \%$ foi determinado a partir de uma classe cuja amplitude foi inferior àquela onde se obteve os $17,11 \%$. Assim haveria a possibilidade de o material apresentar um maior percentual de partículas retidas entre 0,1 e 0,25 mm caso fossem utilizadas classes de peneiras com a mesma amplitude de variação. Pela análise granulométrica ficou evidente a potencialidade do substrato em reter água.

As curvas características de retenção de água (CCRA) foram determinadas em laboratório e os resultados estão apresentados na Tabela 5. Segundo Cadahía López (2000), as CCRA dos solos agrícolas usualmente são determinadas em amplos intervalos de sução ( 0 a $1500 \mathrm{kPa}$ ). Ao contrário, as plantas cultivadas em recipientes não podem ser submetidas a tensões hídricas elevadas, devido ao volume limitado do meio em que se desenvolvem. Sendo assim, a determinação das CCRA em substratos se aplica a intervalos de sução mais estreitos ( 0 a $10 \mathrm{kPa}$ ). Dentro desse limite, são definidos alguns conceitos 
específicos para substratos, o que permite caracterizá-los em termos de disponibilidade de ar (capacidade de aeração) e água (água facilmente disponível, água de reserva e água total disponível). Verificou-se que o modelo de van Genuchten ajustou-se muito bem ass valores observados, podendo-se utilizar as equações obtidas por esse modelo na estimativa dos valores de umidade (Tabela 5).

Tabela 5. Modelo de van Genuchten para ajuste da CCRA em função de doses de condicionador adicionadas ao substrato

\begin{tabular}{ccc}
\hline Condicionador $\left(\mathrm{kg} \mathrm{m}^{-3}\right)$ & Equação $^{1}$ & $\mathrm{R}^{2}$ \\
\hline 0 & $\theta=0,31+\frac{0,65}{\left[1+\left(0,00002739\left|\psi_{\mathrm{m}}\right|\right)^{0,3126}\right]^{15,43}}$ & 0,9962 \\
5 & $\theta=0,31+\frac{0,67}{\left[1+\left(0,006247\left|\psi_{\mathrm{m}}\right|\right)^{0,42}\right]^{3,831}}$ & 0,9943 \\
7,5 & $\theta=0,30+\frac{0,69}{\left[1+\left(0,135\left|\psi_{\mathrm{m}}\right|\right)^{0,6312}\right]^{1,308}}$ & 0,9931 \\
10 & $\theta=0,31+\frac{0,69}{\left[1+\left(0,08183\left|\psi_{\mathrm{m}}\right|\right)^{0,6662}\right]^{1,661}}$ & 0,9874 \\
\end{tabular}

${ }^{1} \theta\left(\mathrm{m}^{3} \mathrm{~m}^{-3}\right) ; \psi_{\mathrm{m}}(\mathrm{kPa}) ; \mathrm{d}_{\mathrm{s}}=0,40 \mathrm{~kg} \mathrm{~m}{ }^{-3}$

A Figura 3 permite a visualização da CCRA do substrato em função de algumas doses do condicionador. Verificou-se que para a dose de condicionador de $10 \mathrm{~kg} \mathrm{~m}^{-3}$, a umidade de saturação foi superior a 100\%. Isso ocorreu em função da expansão do polímero devido a sua hidratação, o que fez com que o material excedesse o volume do cilindro. Para manter o mesmo 
volume controle, poder-se-ia eliminar o material excedente. Entretanto, a retirada desse material, implicaria também na eliminação de uma certa quantidade do polímero, descaracterizando o valor da concentração do condicionador previamente estabelecida. Outra alternativa, seria evitar que o material em excesso ultrapassasse o volume do cilindro, por meio da utilização de um peso na face superior do mesmo. Isso possibilitaria a manutenção do mesmo volume, mas representaria uma condição atípica daquela encontrada nas condições de cultivo. Esse fenômeno também foi observado nas doses de 5 $\mathrm{kg} \mathrm{m}^{-3}$ e $7,5 \mathrm{~kg} \mathrm{~m}^{-3}$ de condicionador.

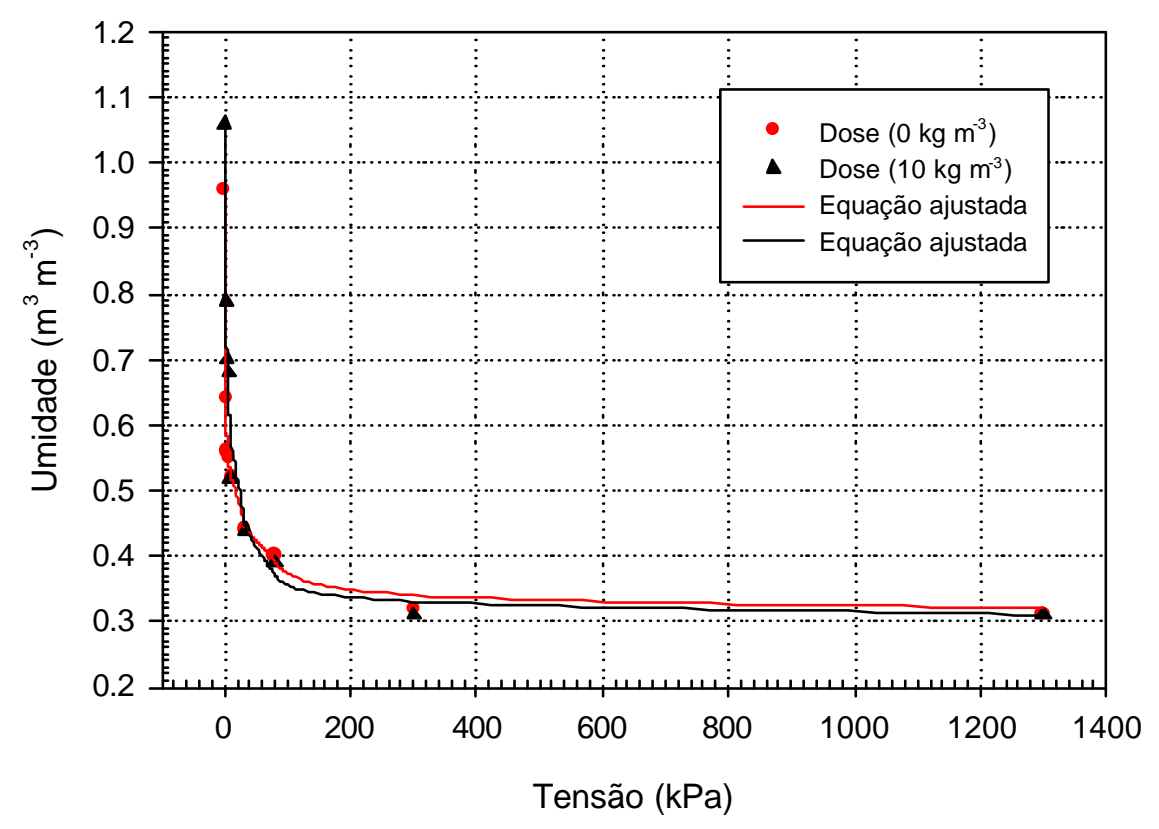

Figura 3 - Curvas características de retenção de água do substrato nas doses de 0 e $10 \mathrm{~kg} \mathrm{~m}^{-3}$ de condicionador.

Verificou-se também, que o ganho em retenção de água com a adição do condicionador ao substrato ocorreu até a tensão de $10 \mathrm{kPa}$. A partir desse ponto, os valores de umidade em função da tensão foram praticamente iguais, independente da dose do condicionador. Esse fato é um bom indicativo de que o condicionador, além de aumentar a retenção de água a baixas tensões, a 
libera facilmente, a ponto de aumentar a sua disponibilidade para as plantas. Uma característica dos substratos àbase de casca de pinus é a capacidade de retenção de água a tensões elevadas. Pela Figura 3 observa-se que esse material foi capaz de reter $32 \%$ de água a uma tensão de $1300 \mathrm{kPa}$, independente da dose de condicionador aplicada. Praticamente, um terço da água retida por esse material não está disponível para as plantas. Resultados similares foram encontrados por Fonteno \& Bilderback (1993), onde a casca de pinus apresentou uma retenção de 35,2\% a uma tensão de $1500 \mathrm{kPa}$.

Com base nas equações geradas pelo modelo de van Genuchten, foi possível estimar a capacidade de aeração (CA), a água facilmente disponível (AFD), a água de reserva (AR) e a água total disponível (ATD) (Tabela 6).

Tabela 6. Armazenamento de água (\% volume) em função de doses do condicionador adicionadas ao substrato

\begin{tabular}{rcccccc}
\hline & \multicolumn{7}{c}{ Condicionador $\left(\mathrm{kg} \mathrm{m}^{-3}\right)$} & & Ótimo \\
& 0 & 2,5 & 5 & 7,5 & 10 & \\
\hline CA & 28 & 23 & 19 & 19 & 19 & $10-30$ \\
AFD & 11 & 14 & 18 & 16 & 20 & $20-30$ \\
AR & 5 & 6 & 8 & 8 & 10 & $4-10$ \\
ATD & 16 & 20 & 26 & 24 & 30 & $24-40$ \\
\hline
\end{tabular}

${ }^{1}$ Níveis ótimos segundo Abad et al. (1992);

CA - capacidade de aeração ( 0 a $1 \mathrm{kPa})$;

AFD - água facilmente disponível (1 a $5 \mathrm{kPa}$ );

$A R$ - água de reserva (5 a $10 \mathrm{kPa})$;

ATD - água total disponível (1 a $10 \mathrm{kPa}$ ).

Verificou-se uma diminuição na $\mathrm{CA}$ em função do aumento da concentração do condicionador. Isso ocorreu devido à expansão do 
condicionador, diminuindo a macroporosidade responsável pela aeração do substrato. Essa diminuição poderia ser mais significativa, caso fosse mantido 0 mesmo volume controle. Observourse também uma aumento da ATD (AFD + AR) em função das doses crescentes do condicionador, característica desejável no cultivo em recipientes, principalmente naqueles de menor volume. Esse aumento foi devido à maior retenção em baixas tensões $(<10 \mathrm{kPa})$, visto que em tensões maiores, a retenção foi a mesma.

Quando comparado com os níveis ótimos sugeridos por Abad et al. (1992), a AFD ficou abaixo do limite inferior de $20 \%$, exceto para a maior dose do condicionador. Já para a ATD, apenas nas doses de $5 \mathrm{~kg} \mathrm{~m}^{-3}, 7,5 \mathrm{~kg} \mathrm{~m}^{-3} \mathrm{e}$ $10 \mathrm{~kg} \mathrm{~m}^{-3}$ de condicionador, os valores encontraram-se dentro dos níveis ótimos. Essas informações são muito importantes, pois o bom desenvolvimento das plantas depende do balanço adequado entre o espaço poroso e a disponibilidade de água. Conhecendo-se previamente as propriedades físicas do material a ser utilizado como substrato, é possível utilizar de técnicas eficientes para melhorar suas características. Por exemplo, seria possível aumentar o valor da AFD e diminuir um pouco a CA, por meio da utilização de aditivos (ex., areia fina). Bragg \& Chambers, citado por Ansorena Miner (1994) verificaram que a adição de areia fina $(<1 \mathrm{~mm})$ em turfa promoveu uma diminuição da capacidade de aeração, devido ao bloqueio dos poros maiores da turfa pelas partículas finas da areia. A redução da macroporosidade possibilita um aumento na retenção de água. Assim, seria possível melhorar as propriedades físicas do substrato utilizado no experimento mediante a adição de areia fina.

Realizou-se a determinação da condutividade hidráulica do substrato saturado $\left(K_{\mathrm{s}}\right)$ na presença de doses crescentes de condicionador e os resultados se encontram na Figura 4. 


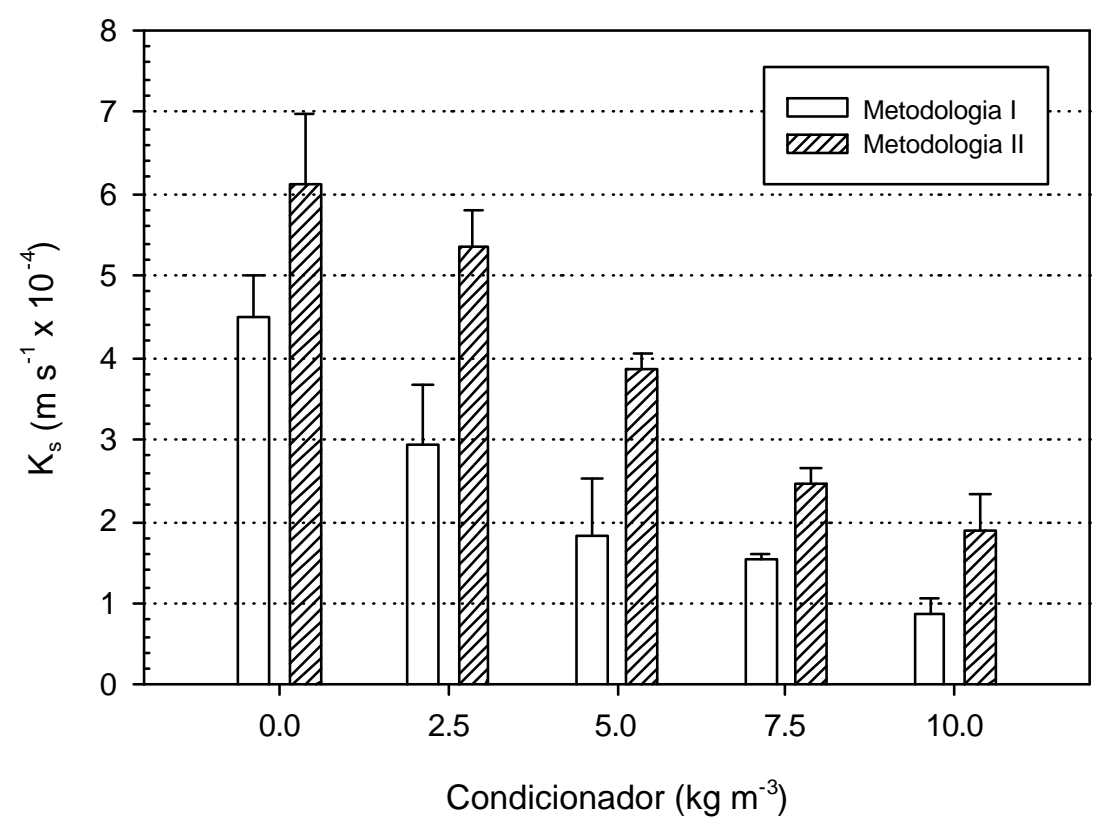

Figura 4 - Condutividade hidráulica do substrato saturado em função de doses do condicionador, em duas metodologias de determinação.

Verificou-se que, independente da metodologia adotada, os valores de $\mathrm{K}_{\mathrm{s}}$ diminuíram com o aumento da dose do condicionador. Essa diminuição foi decorrente da expansão do condicionador e conseqüente redução da macroporosidade e permeabilidade do material. A diferença entre as metodologias pode ser explicada pela restrição oferecida à expansão do condicionador. Na metodologia I foi utilizado papel filtro entre o cilindro contendo o substrato e o cilindro utilizado para a formação da carga hidráulica. Esse papel ofereceu certa resistência à expansão do condicionador, evitando o aumento do volume do substrato. O resultado foi uma diminuição significativa da macroporosidade com a redução nos valores de $K_{s}$. Na ausência do papel filtro (metodologia II), não houve restrição à expansão do condicionador permitindo assim, o aumento do tamanho dos poros e, consequentemente, maiores valores para Ks. Embora utilizando solo mineral, a mesma tendência foi observada nos trabalhos de Prevedello \& Balena (2000). É possível que em substratos orgânicos os efeitos da adição de condicionador nos valores de $K_{s}$ 
sejam mais significativos. Os componentes presentes nesse tipo de material apresentam valores de densidade de partícula inferiores aos componentes dos solos minerais. Assim, podem oferecer menor resistência quando da expansão dos polímeros hidroabsorventes.

\subsection{Propriedades físico-hídricas e químicas do condicionador}

Foram realizados vários ensaios para a caracterização do condicionador utilizado no experimento. O primeiro referiu-se à absorção do

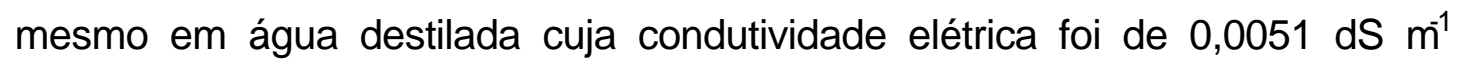
(Figura 5).

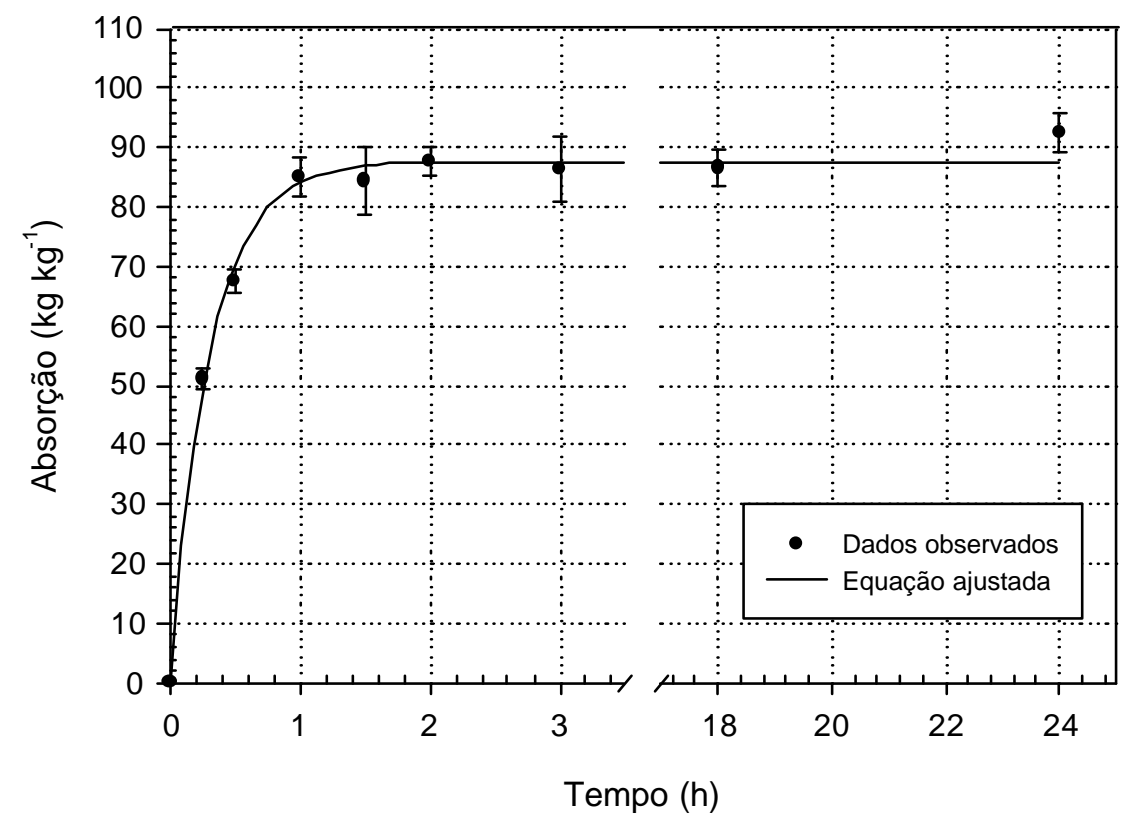

Figura 5 - Curva de absorção do condicionador em função do tempo.

Verificou-se que a absorção foi muito intensa nas primeiras duas horas, estabilizando-se a um valor de aproximadamente $90 \mathrm{~kg} \mathrm{~kg}^{-1}$ até o final do período de ensaio. A rápida absorção inicial parece ser uma característica 
evidente na maioria dos polímeros hidroabsorventes, alcançando a máxima absorção em poucas horas. Esse comportamento também foi observado por Bowman et al. (1990) e Wang \& Gregg (1990), entretanto a níveis de absorção diferenciados em função das propriedades químicas do polímero e da condutividade elétrica da água utilizada no processo de absorção.

O elevado potencial de absorção dos polímeros quando submetidos à saturação em água não é o mesmo quando misturados em meios de cultivo, seja solo ou substrato. Quando as amostras de substrato com doses crescentes de condicionador, foram submetidas à saturação para a realização da CCRA, esperava-se um aumento significativo na retenção, visto a capacidade de absorção do condicionador observada no ensaio da Figura 5. As umidades no ponto de saturação observadas na ausência de condicionador e na maior concentração avaliada $\left(10 \mathrm{~kg} \mathrm{~m}^{-3}\right)$, foram respectivamente, $2,39 \mathrm{~kg} \mathrm{~kg}^{-1}$ e 2,65 $\mathrm{kg} \mathrm{kg}^{-1}$, o que representou um aumento de 10,9\% na retenção de água. Fonteno \& Bilderback (1993) chegaram à mesma constatação. Esses autores recuperaram os polímeros hidratados de uma amostra de substrato a base de casca de pinus, quando essa mesma amostra se encontrava na condição de umidade denominada "capacidade de container" (CC). Verificaram que os polímeros expandiram-se muito menos no substrato do que em água destilada e atribuíram o fato a duas possíveis causas: falta de água livre no substrato na condição de $\mathrm{CC}$ e a resistência física oferecida pelo substrato à expansão do polímero. Essa constatação mostra que, em condições reais de cultivo, o potencial de retenção de água dos polímeros fica limitado.

O outro fator que pode agravar a utilização desses polímeros em meios de cultivo refere-se àsua absorção em soluções salinas (Figura 6). 


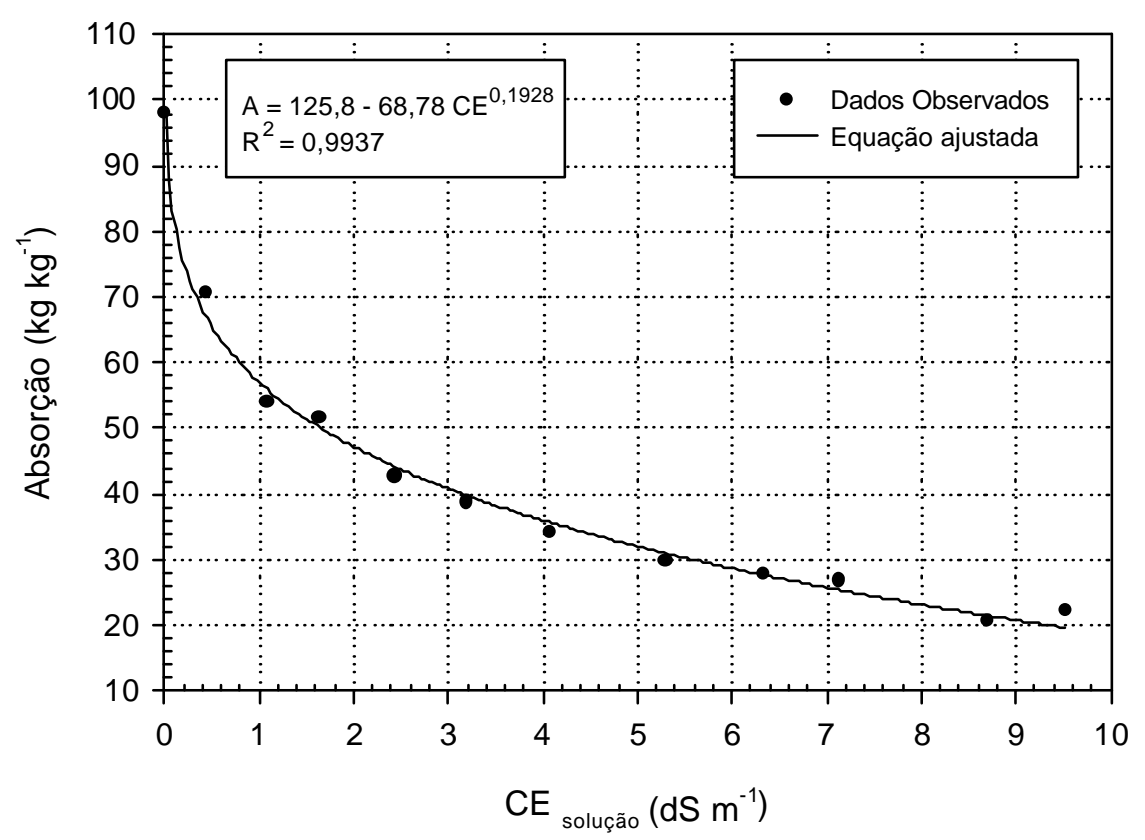

Figura 6 - Curva de absorção do condicionador em função da condutividade elétrica da solução.

Foi observada uma redução de $79,45 \%$ na absorção do polímero quando a solução de hidratação passou de $0,0051 \mathrm{dS} \mathrm{m}^{-1}$ para $9 \mathrm{dS} \mathrm{m}^{-1}$. Resultados similares foram observados por Johnson (1984) onde a hidratação de polímeros de acrilamida foi reduzida em mais de $75 \%$ na presença de água salina ( $C E=3,2 \mathrm{dS} \mathrm{m}^{-1}$ ) em relação à hidratação máxima em água deionizada. Bowman et al. (1990) constataram que a intensidade de redução na absorção está relacionada àvalência dos íons presentes na solução, ou seja, a absorção foi mais afetada pela presença de cátions bivalentes. Pela Figura 6 , também foi verificado que a taxa de redução na absorção foi mais acentuada até o valor de aproximadamente $1,5 \mathrm{dS} \mathrm{m}^{-1}$ (redução de $49 \%$ ). Num sistema produtivo, valores de condutividade elétrica da solução ao redor de $1,5 \mathrm{dS} \mathrm{m}^{-1}$ são considerados adequados para o desenvolvimento de várias culturas. Entretanto, esse mesmo valor de condutividade foi suficiente para limitar significativamente a hidratação dos polímeros presentes no substrato. Essa situação pode ocorrer com muita freqüência nos sistemas de produção de mudas em tubetes. Nesse 
sistema, a concentração dos nutrientes no substrato é elevada face ao reduzido volume dos recipientes, e poderá ser ainda maior com a utilização de fertilizante de liberação controlada. Esses fertilizantes apresentam a característica de liberação gradual em função da temperatura do meio. Por ser de liberação controlada muitos viveiristas utilizam esse fertilizante de forma a aplicar a quantidade necessária para todo o ciclo, na expectativa de atender gradualmente a demanda da planta. No caso do cafeeiro, as mudas ficam nos tubetes por um período de 4 a 5 meses, fazendo com que as doses desse tipo de fertilizante, aplicadas no início do ciclo, sejam elevadas. A grande maioria dos viveiros não dispõem de um controle automático das variáveis climáticas, e assim o viveirista fica impossibilitado de controlar a liberação do fertilizante. Uma liberação mais acelerada desse fertilizante poderia resultar no aumento da salinidade do substrato e assim inibir a expansão dos polímeros hidroabsorventes eventualmente incorporados ao substrato. Bowman et al. (1990), estudando a hidratação de polímeros na presença de sais fertilizantes, consideraram improvável que a adição de hidrogéis aumente a capacidade de retenção de água dos substratos, principalmente em sistemas de produção em estufas e viveiros de mudas, onde os níveis de adubação utilizados são elevados.

$\mathrm{Na}$ expectativa de verificar a recuperação das características de absorção do condicionador, realizoutse um ensaio de reabsorção e os resultados encontram-se na Figura 7. 


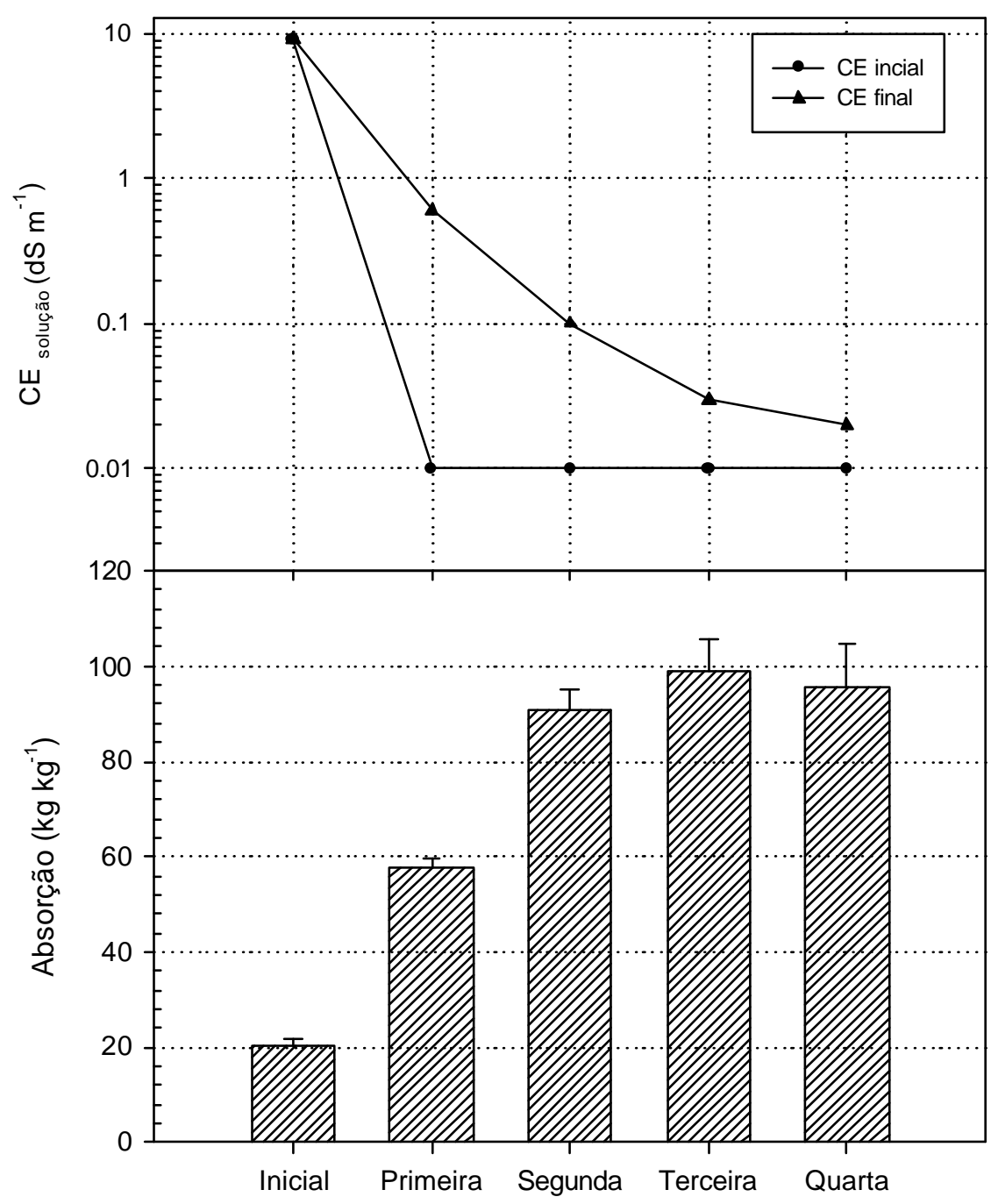

Figura 7 - Reabsorção do condicionador em água destilada após hidratação inicial em solução salina.

Verificou-se que no terceiro dia de hidratação em água destilada, o condicionador recuperou sua absorção potencial. Essa recuperação aconteceu devido à redução da concentração dos íons presentes na solução. A partir do primeiro ciclo de hidratação em água destilada, observou-se que os íons, até então retidos no condicionador, foram deslocados para a solução, aumentando a sua condutividade elétrica ao final de cada etapa de hidratação. Ao longo dos ciclos de hidratação, verificourse uma aproximação dos valores da 
condutividade elétrica final e inicial. A medida que o condicionador era separado da solução para iniciar um novo ciclo de hidratação, œs íons presentes na solução eram eliminados e os que restavam aderidos no condicionador entravam em equilíbrio com a nova solução, formada pela adição de água destilada. Esses resultados provaram a capacidade de reabsorção do condicionador, mostrando que o processo pode ser reversível. Num sistema produtivo, poder-se-ia recuperar a atividade do condicionador adicionado ao substrato, por meio da aplicação de uma lâmina de irrigação excessiva para promover a lixiviação dos sais. Entretanto, as condições de cultivo não permitem essa rápida recuperação, visto que o meio não se encontra saturado (presença de água livre) como nos ensaios laboratoriais. Um outro agravante é que uma prática dessa natureza, visando a hidratação do condicionador e aumento da capacidade de retenção de água do substrato, levaria a perdas significativas dos nutrientes pelo processo de lixiviação, podendo causar deficiências nutricionais nas plantas. Os excelentes resultados obtidos em laboratório, principalmente em termos de absorção e reabsorção, não são os mesmos quando da utilização do condicionador em meios de cultivo intensivos, o que pode inviabilizar a sua aplicação, principalmente em função do seu custo elevado.

\subsection{Aspectos relacionados àirrigação}

Conforme descrito na metodologia, foram aplicadas cinco lâminas de irrigação, sendo quatro baseadas na evaporação do minitanque e uma fixa, denominada controle e independente da demanda local. Nesse tratamento controle foi aplicada uma lâmina diária de $2,5 \mathrm{~mm}$ no período compreendido entre o vigésimo sétimo dia após a repicagem (DAR) até o desenvolvimento completo do segundo par de folhas (93 DAR). A partir desse dia até o final do experimento (149 DAR), aplicou-se uma lâmina de irrigação diária de 4 mm. Como eram conhecidos os valores diários de evaporação do minitanque, foi 
possível relacioná-los com os da lâmina controle ao longo de todo o ciclo de produção da muda (Figura 8).

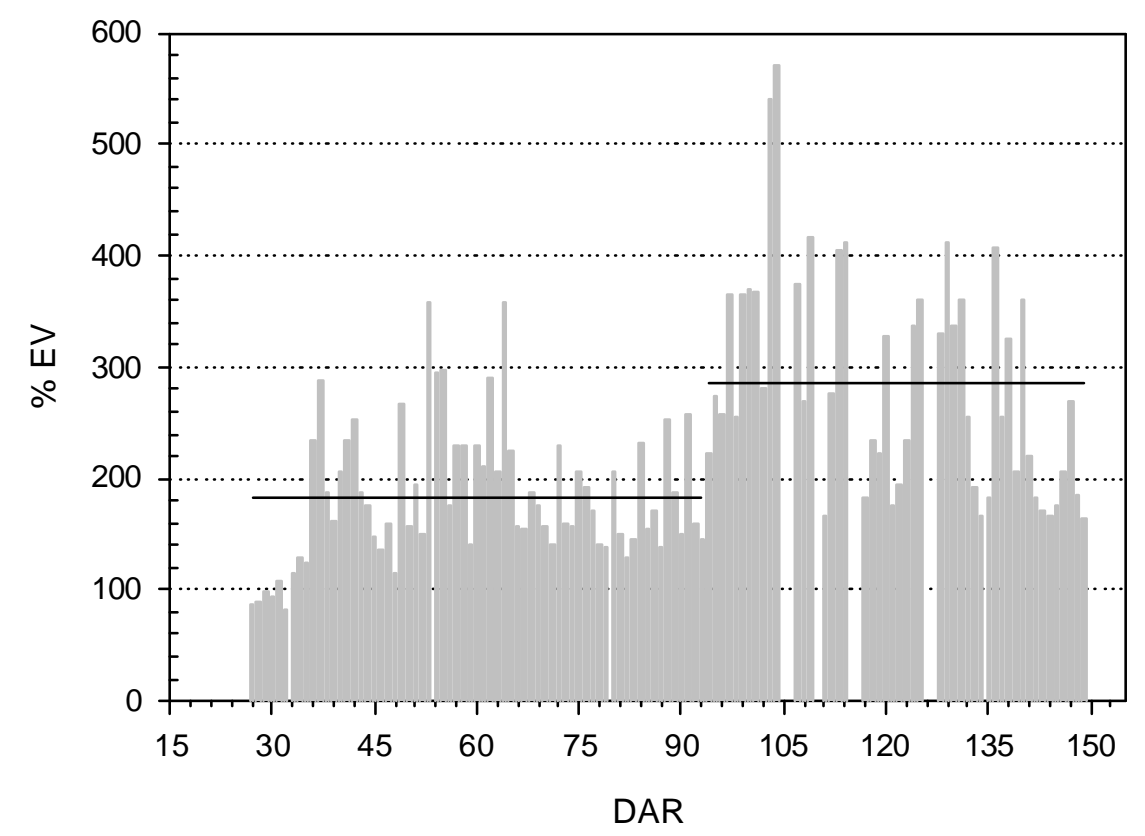

Figura 8 - Percentual equivalente da lâmina controle em relação a evaporação do minitanque, durante todo período experimental.

Verificou-se que na primeira fase, a aplicação de uma lâmina diária de $2,5 \mathrm{~mm}$ representou em média $183 \%$ da evaporação diária no minitanque. Já para a segunda fase, o aumento da lâmina aplicada (4 $\left.\mathrm{mm} \mathrm{dia}^{-1}\right)$, representou em média, 285\% da evaporação diária. Esses valores percentuais podem ser explicados em parte, pela baixa demanda atmosférica no interior da casa de vegetação. Os dados da Tabela 7 mostraram valores reduzidos de radiação global em função da cobertura de polietileno e do sombrite $50 \%$. Particularmente para a segunda fase de manejo da irrigação, que coincidiu com as estações de outono/inverno, os valores percentuais poderiam também ter sido afetados pelas temperaturas mais amenas. 
Tabela 7. Dados meteorológicos monitorados no interior da casa de vegetação durante o período experimental

\begin{tabular}{ccccccc}
\hline Mês & DAR & $\mathrm{T}_{\mathrm{m}}\left({ }^{\circ} \mathrm{C}\right)^{1}$ & $\mathrm{UR}_{\mathrm{m}}(\%)^{1}$ & $\begin{array}{c}\mathrm{Q}_{g} \\
\left(\mathrm{MJ} \mathrm{m}^{-2} \mathrm{mês}^{-1}\right)\end{array}$ & $\begin{array}{c}\mathrm{R}_{\mathrm{n}} \\
\left(\mathrm{MJ} \mathrm{m}^{-2} \mathrm{mês}^{-1}\right)\end{array}$ & $\begin{array}{c}\mathrm{R}_{\mathrm{n}} / \mathrm{Q}_{g} \\
(\%)\end{array}$ \\
$\begin{array}{c}\text { Março } \\
\text { (26/03 a 31/03/02) }\end{array}$ & até 2 & $25,0 \pm 0,7^{2}$ & $84,0 \pm 3,7^{2}$ & 48,5 & 44,6 & 92,0 \\
Abril & $3-32$ & $24,3 \pm 0,9$ & $80,1 \pm 2,4$ & 208,5 & 182,0 & 87,3 \\
Maio & $33-63$ & $20,4 \pm 2,3$ & $87,2 \pm 3,4$ & 148,7 & 135,8 & 91,3 \\
Junho & $64-93$ & $19,7 \pm 1,2$ & $83,9 \pm 2,3$ & 138,4 & 129,8 & 93,8 \\
Julho & $94-124$ & $17,5 \pm 2,4$ & $84,9 \pm 4,6$ & 128,3 & 117,3 & 91,4 \\
$\begin{array}{c}\text { Agosto } \\
\text { (01/08 a 25/08/02) }\end{array}$ & $125-149$ & $21,5 \pm 1,2$ & $79,3 \pm 7,3$ & 124,7 & 121,5 & 97,4 \\
\hline
\end{tabular}

${ }^{1}$ Média de 4 psicrômetros;

${ }^{2}$ Desvio padrão;

$T_{m}$ - temperatura média; $U R_{m}$ - umidade relativa média; $Q_{g}$ - radiação global;

$\mathrm{R}_{\mathrm{n}}$ - radiação líquida.

Na Figura 8, observa-se que em praticamente todo o ciclo, a lâmina controle foi sempre superior à lâmina evaporada no minitanque. As variações percentuais também foram acentuadas, mostrando que em dias ensolarados, nos quais a demanda atmosférica era maior, os valores percentuais foram menores. Em dias nublados e chuvosos foram verificados valores percentuais acima de $400 \%$, principalmente no período em que foram aplicadas lâminas diárias de $4 \mathrm{~mm}$. Nas condições em que o experimento foi conduzido, os valores percentuais médios, calculados para a lâmina controle, foram superiores aos demais tratamentos.

Estimativas da evapotranspiração de referência pelo método de Penman-Monteith mostraram que na primeira fase, a aplicação de uma lâmina diária de $2,5 \mathrm{~mm}$ representou em média $230 \%$ da evapotranspiração diária 
ocorrida no interior da casa de vegetação. Já para a segunda fase, o aumento da lâmina aplicada (4 $\left.\mathrm{mm} \mathrm{dia}^{-1}\right)$, representou em média, $486 \%$ da evapotranspiração diária.

A Figura 9 mostra a lâmina planejada (meta) e as lâminas reais armazenadas nos tubetes, em função dos valores percentuais de evaporação no minitanque.

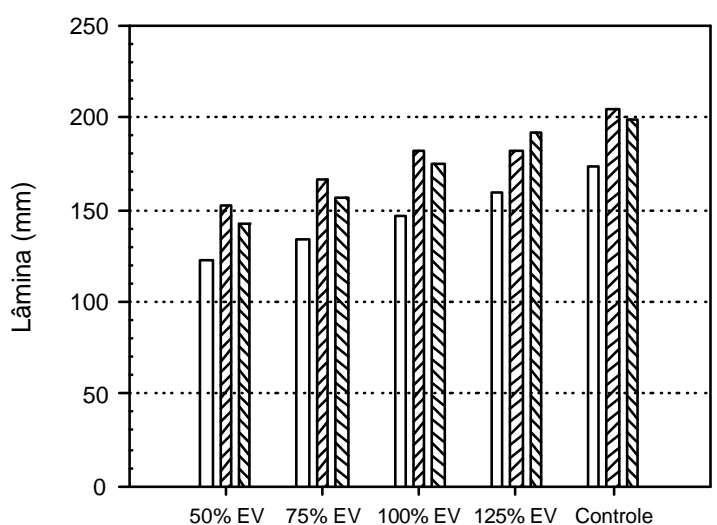

(a)

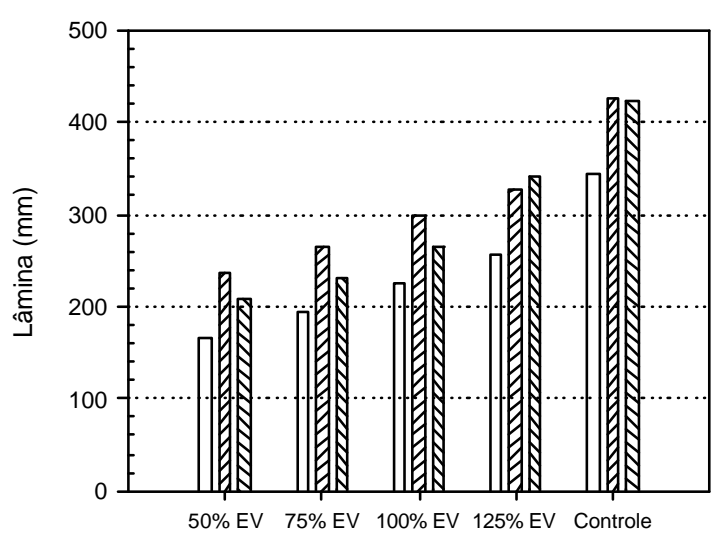

(c)

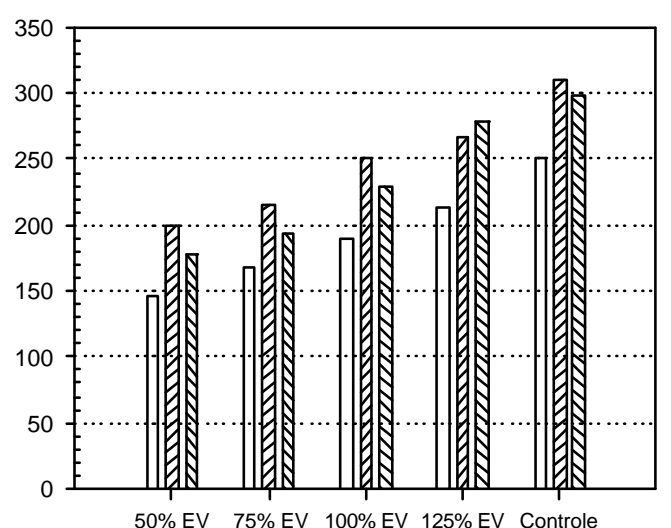

(b)

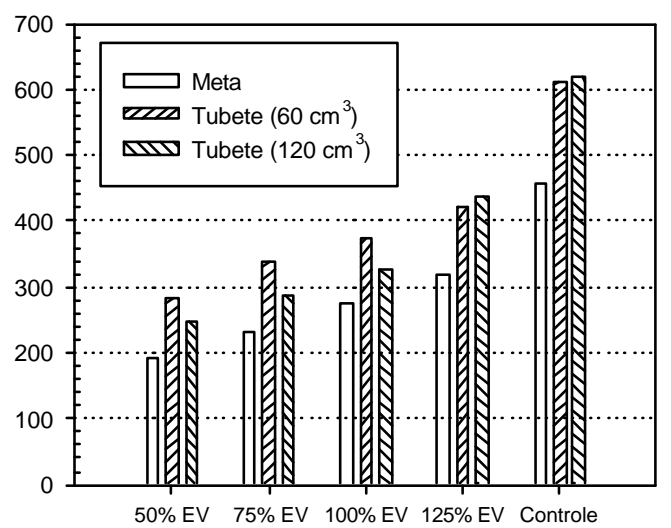

(d)

Figura 9 - Lâmina planejada (meta) e lâminas reais armazenadas nos tubetes, em função dos valores percentuais da evaporação no minitanque, durante o período experimental. Lâminas acumuladas aos 57 DAR (a), aos 88 DAR (b), aos 118 DAR (c) e aos 149 DAR (d). 
A meta foi considerada como sendo a lâmina que deveria ser armazenada no interior dos tubetes, ou seja, praticamente a mesma que atingiu o dossel das plantas. Entretanto, observourse que a lâmina de água armazenada nos dois tubetes testados foi superior à meta, mostrando uma eficiência superior a $100 \%$. Esse fato ocorreu em função da arquitetura da planta, a qual funcionava como um coletor, convergindo a água captada para 0 interior do tubete. Verificourse que nos tubetes menores, as lâminas armazenadas foram superiores à dos tubetes maiores. Em condições normais de desenvolvimento, as plantas apresentam em média a mesma área foliar, podendo coletar um mesmo volume de água e convergi-lo para o interior dos tubetes. Como os tubetes menores apresentam menor seção, a lâmina infiltrada passa a ser maior que nos tubetes maiores. Aos 149 DAR foi observado, no tratamento controle, que a lâmina armazenada nos tubetes de $120 \mathrm{~cm}^{3}$ foi superior àquela do tubete de $60 \mathrm{~cm}^{3}$. Esse tratamento foi o que proporcionou 0 maior desenvolvimento das mudas e nessa fase, em função da maior demanda das plantas, o volume do tubete menor passou a limitar a disponibilidade de água para as mesmas. A falta de água evou ao murchamento de algumas mudas, fazendo com que as folhas cobrissem a seção do tubete (efeito "guarda-chuva"), impossibilitando a infiltração da água por ocasião das irrigações. A Figura 10 ilustra as arquiteturas de plantas que convergem água para o interior dos tubetes e daquelas que impossibilitam a entrada de água, simulando um efeito "guarda-chuva". Além do estresse hídrico, outros fatores podem ter levado ao murchamento das mudas, como o selamento superficial do substrato provocado por algas, as quais se desenvolvem na presença de luz, água e nutrientes. Nas situações em que são utilizados fertilizantes de liberação controlada e que não se tem o controle de sua liberação, podem haver disponibilidade excessiva de nutrientes possibilitando o desenvolvimento das algas que num primeiro momento apresentam um aspecto pastoso (Figura 11a). Com o tempo, em função da evaporação da água, as algas formam com o substrato superficial uma película seca e impermeável à infiltração da água 
(Figura 11b). Uma alternativa para solucionar esse problema, seria a possibilidade de redução na adubação de base quando da utilização de fertilizantes de liberação controlada, complementando as necessidades da cultura ao longo do ciclo.

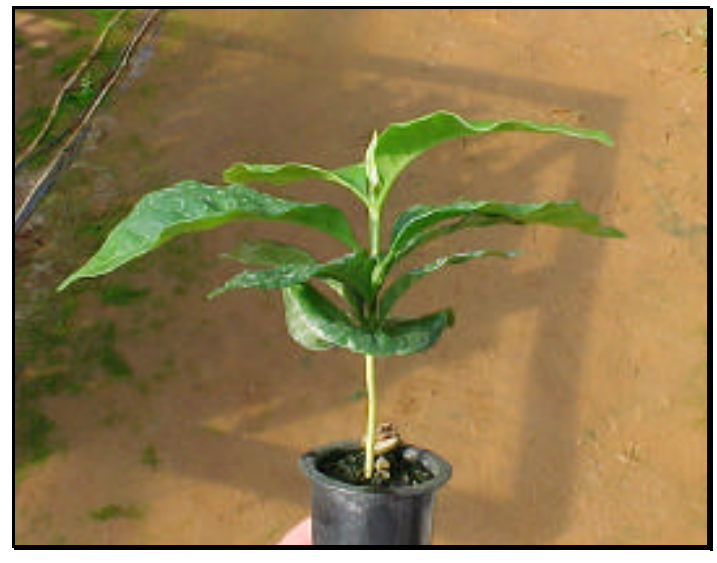

(a)

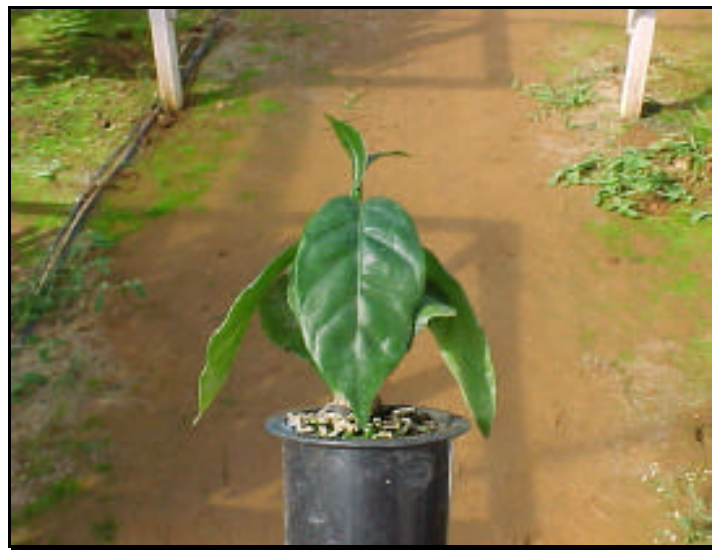

(b)

Figura 10 - Arquitetura foliar de mudas de cafeeiro. Muda que converge água para o interior do tubete (a) e muda que não converge água simulando efeito "guarda-chuva" (b).

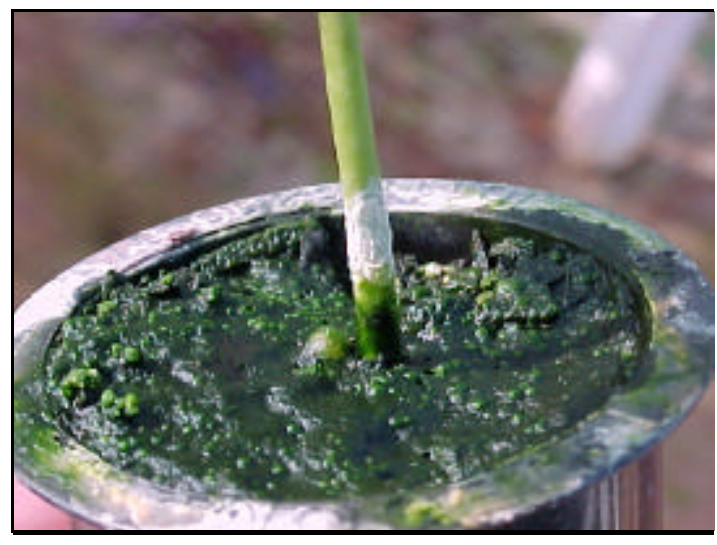

(a)

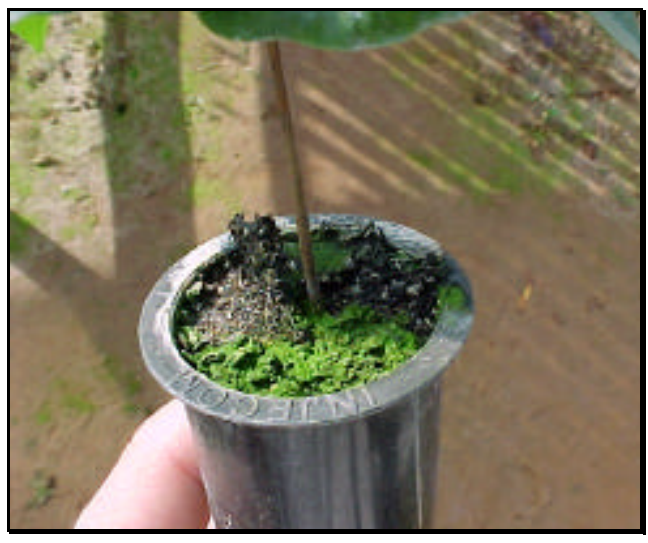

(b)

Figura 11 - Selamento superficial devido ao desenvolvimento de algas. Fase inicial com aspecto pastoso (a) e película seca e impermeável à infiltração de água (b). 
Acredita-se que a definição das lâminas baseadas na evaporação do minitanque ficou aquém das necessidades reais das mudas de cafeeiro, visto que aos 88 DAR já se notava um elevado percentual de mortalidade das plantas que receberam uma lâmina de $50 \%$ EV ( $86 \%$ de mortalidade), principalmente nos tubetes de $60 \mathrm{~cm}^{3}$ (Figura 12).
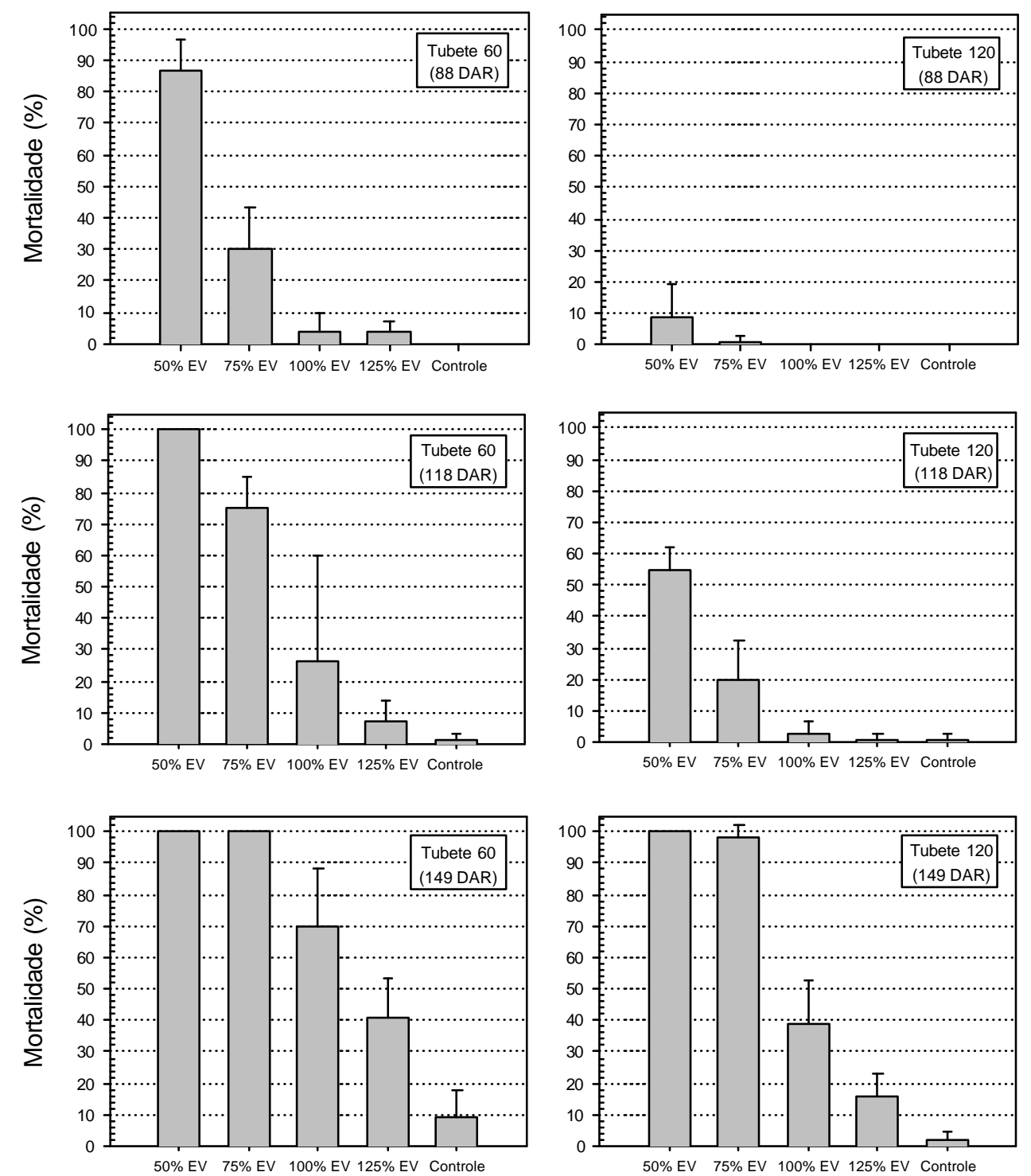

Figura 12 - Mortalidade de mudas de cafeeiro em função das lâminas de irrigação e tamanhos de tubetes, durante o período experimental. 
No mesmo período e para a mesma lâmina, a taxa de mortalidade das mudas cultivadas nos tubetes de $120 \mathrm{~cm}^{3}$ já se encontrava ao redor de $10 \%$. Aos 118 DAR, houve $100 \%$ de mortalidade das mudas nos tubetes de $60 \mathrm{~cm}^{3}$, sob o nível de irrigação de $50 \% \mathrm{EV}$. Nessa época, o tratamento correspondente ao regime de irrigação de $75 \% \mathrm{EV}$ já apresentava $75 \%$ de mortalidade das mudas. Ao final do experimento (149 DAR), praticamente todas as mudas cultivadas sob os níveis de irrigação de $50 \%$ EV e $75 \%$ EV morreram, independente do tamanho do tubete. A principal causa do elevado percentual de mortalidade foi o déficit hídrico acumulado por esses tratamentos. Essa causa ficou evidente quando se observou que em todas as épocas avaliadas e independente da quantidade de água aplicada, a mortalidade das mudas cultivadas nos tubetes de $60 \mathrm{~cm}^{3}$ foi superior àquela observada nos tubetes de $120 \mathrm{~cm}^{3}$. Esses, por apresentarem um maior volume, armazenaram uma maior quantidade de água, retardando os efeitos do déficit hídrico e, consequentemente, o murchamento das mudas. Aos 149 DAR, verificou-se uma taxa de mortalidade de $10 \%$ nas plantas cultivadas nos tubetes de $60 \mathrm{~cm}^{3}$, quando irrigadas com a lâmina controle. Essa taxa de mortalidade foi resultado da redução da lâmina de água infiltrada no tubete de $60 \mathrm{~cm}^{3}$, devido ao murchamento das mudas, como explicado anteriormente (Figura 9d).

Outros fatores contribuíram para acelerar a mortalidade das plantas, tais como a forma de preparo do substrato e o manejo inicial da irrigação. Como apresentado anteriormente, a mistura contendo substrato comercial, fertilizante de liberação controlada e condicionador, foi obtida por meio de sua homogeneização em betoneira. $O$ fabricante do substrato recomenda a utilização de 5 litros de água para cada $25 \mathrm{~kg}$ de substrato comercial, no processo de homogeneização. A adição de água é feita com o objetivo de promover o umedecimento inicial do substrato, principalmente quando da presença de componentes como cascas vegetais. O substrato comercial utilizado no experimento apresentava em sua composição casca de pinus, material esse que possui característica hidrofóbica quando seco. Assim, esse 
contato prévio da água no processo de homogeneização possibilitaria um umedecimento mais eficiente dos componentes do substrato, o que seria mais difícil conseguir por meio do sistema de irrigação. Testes preliminares foram realizados e verificou-se que com o movimento rotativo da betoneira, o substrato se agregava formando partículas grandes, prejudicando a obtenção de uma mistura homogênea quando da adição dos demais componentes. A maior preocupação foi com o condicionador, pois além de sua pequena proporção na mistura, o mesmo apresenta elevada higroscopicidade, o que poderia dificultar a sua homogeneização na presença de água. Dessa forma, optou-se pela mistura sem a adição de água, uma vez que o substrato já apresenta uma umidade em torno de $50 \%$.

O outro ponto a ser destacado refere-se ao manejo inicial da irrigação. Após a repicagem das mudas nos tubetes, iniciourse a fase de condução denominada "pegamento das mudas". Essa fase correspondeu a um período de 23 dias e a quantidade total de água aplicada foi de $95 \mathrm{~mm}$. Desse total, $24 \mathrm{~mm}$ foram aplicados durante o processo de repicagem e aproximadamente $13 \mathrm{~mm}$ (lâmina de uniformização), aplicado no dia que antecedeu o início da diferenciação das lâminas de irrigação. O restante, correspondente a $58 \mathrm{~mm}$, representou a aplicação de uma lâmina equivalente a $100 \%$ da evaporação do minitanque acumulada nesse período. Em média, essa lâmina representou uma aplicação diária de 2,52 \pm 0,32 mm, considerada a evaporação média do minitanque durante esse período. Como não há informações específicas na literatura a respeito do manejo da irrigação na fase inicial de pegamento de mudas de cafeeiro, adotou-se esse critério baseado no conhecimento de que na fase inicial de desenvolvimento, a evapotranspiração das culturas é menor que a evaporação de uma superfície livre de água, como é o caso do minitanque. Assim, poder-se-ia admitir que a aplicação de uma taxa de $100 \%$ da EV estaria suprindo a demanda da muda em sua fase inicial de desenvolvimento. Embora a recomendação de Guimarães et al. (1998) não considere a demanda climática local, esses autores sugerem a aplicação de 2,5 mm diários até o estádio de 
desenvolvimento "orelha de onça". Verificourse assim, que apesar do empirismo na definição do percentual da evaporação do minitanque, as lâminas aplicadas foram praticamente as mesmas sugeridas na recomendação desses autores. A diferença é que no experimento, não houve o umedecimento inicial do substrato no ato da preparação da mistura, o que pode ter interferido nos resultados obtidos.

Assim, a não utilização de água no preparo do substrato e o manejo de irrigação inicial $(100 \% \mathrm{EV})$ após o processo de repicagem, possivelmente contribuíram de forma significada para as elevadas taxas de mortalidade.

Acredita-se que o procedimento correto seria a aplicação do volume de água recomendado pelo fabricante no đo da preparação da mistura. Com o auxílio de um pulverizador, os 5 litros seriam aplicados lentamente, possibilitando a sua absorção pela casca de pinus. Posteriormente ao enchimento dos tubetes, deveria ser feita uma irrigação intensiva para garantir o umedecimento do material. Nem mesmo a irrigação de uniformização, aplicada após o período de pegamento, foi suficiente para o umedecimento do substrato. Conforme descrito na metodologia, essa lâmina foi definida com o auxílio de uma seringa, aplicando-se uma quantidade de água, em alguns tubetes controle, até que se iniciasse a drenagem na base inferior dos mesmos. Como a intensidade de aplicação da seringa foi elevada e o substrato se encontrava seco, possivelmente criou-se um caminho preferencial, o que subestimou a quantidade necessária de água para o umedecimento do substrato.

Face a elevada taxa de mortalidade, apenas as plantas do tratamento controle alcançaram o final do experimento. Como visto anteriormente, as mudas de cafeeiro apresentam uma arquitetura foliar que possibilita a conversão de água para o interior do tubete, aumentando a eficiência da irrigação. No caso específico do sistema de produção de mudas de cafeeiro em tubetes, foi observado que a eficiência da irrigação depende do sistema de irrigação, da arquitetura e cerosidade das folhas e do arranjamento dos tubetes na bancada. Quanto ao sistema de irrigação, o tipo de emissor, o tamanho e 
direção da gota e a lâmina aplicada afetam a eficiência da irrigação. Gotas maiores apresentam maior energia cinética o que possibilita uma maior penetração da água no interior da planta. As lâminas estão associadas à características hidrofílicas das folhas. Quando lâminas pequenas são aplicadas sobre uma superfície foliar hidrofílica, parte dessa lâmina ficará retida nas folhas, não atingindo o alvo final que é o substrato. A disposição dos tubetes na bancada é muito importante. Como visto na metodologia, os tubetes foram dispostos em linhas alternadas e espaçados entre si de uma malha de tela, de modo que toda a água precipitada nesses espaços vazios era perdida. Ao contrário do sistema de produção de mudas de hortaliças em que as bandejas são encostadas umas as outras, toda água precipitada fica contida na bandeja, reduzindo as perdas.

Para avaliar a eficiência da irrigação no sistema de produção de mudas em tubetes, foram utilizadas apenas as plantas desenvolvidas nos tubetes de $120 \mathrm{~cm}^{3}$, irrigadas com a lâmina controle, de modo a retratar as condições reais de um viveiro comercial (Figura 13). Foi observado que independente da época de avaliação, a eficiência da irrigação em todas as repetições foi superior a $100 \%$. O motivo, já mencionado anteriormente, se resume em uma maior área de coleta representada pelas folhas das plantas, que convergem a água interceptada para $o$ interior dos tubetes. A relação entre o volume retido e a seção do tubete representa a lâmina armazenada no interior do mesmo, a qual é maior do que aquela que atinge o dossel das plantas. Verificou-se que ao longo do ciclo de cultivo, as eficiências aumentavam e diminuíam de forma seqüencial. Esse comportamento está relacionado com os lançamentos foliares da planta. No cafeeiro as folhas são opostas e alternas de modo que numa visualização frontal, após dois lançamentos foliares, é possível visualizar basicamente quatro folhas. Assim, parte dessa área formada pelas quatro folhas foi a responsável pela coleta da água que atingiu o interior do tubete. Com o lançamento e desenvolvimento do terceiro par de folhas, ocorreu a sobreposição das folhas do primeiro lançamento. Fica claro que essas 
sobreposições alteram a área útil responsável pela coleta de água, afetando assim os valores de eficiência.
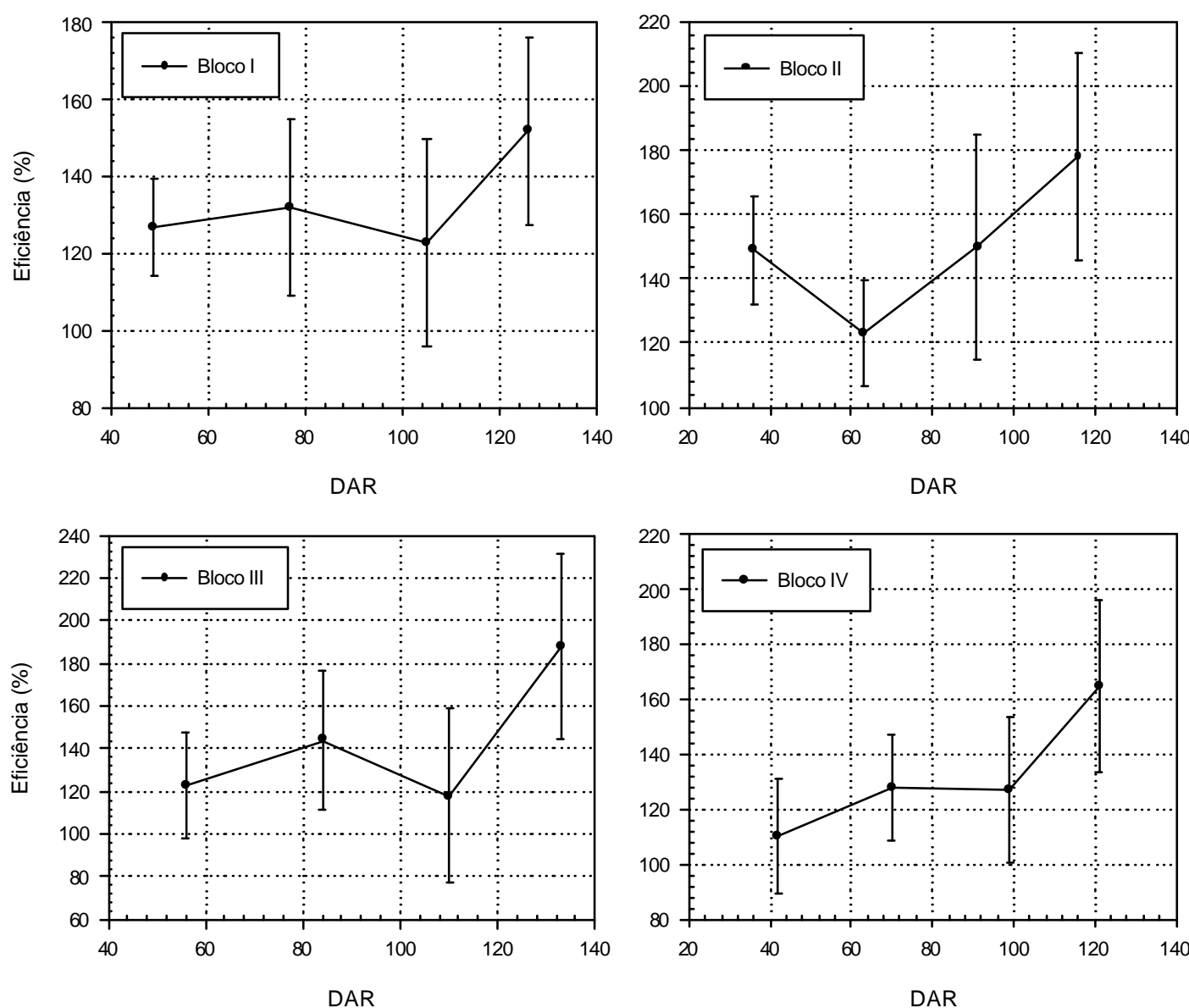

Figura 13 - Eficiência da irrigação para mudas cultivadas em tubetes de 120 $\mathrm{cm}^{3} \mathrm{e}$ irrigadas com a lâmina controle.

$\mathrm{Na}$ Figura 13, as barras verticais representam os coeficientes de variação das médias de eficiência (calculados a partir de 15 observações). Foi observado que o coeficiente de variação aumentou durante o período experimental em todas as repetições. Esse fato ocorreu devido ao aumento da área foliar, o que fez com que as plantas cobrissem toda a extensão da bancada. Como esse crescimento ocorre aleatoriamente, a distribuição da água 
após atingir o dossel da planta também é feita de forma aleatória, o que pode ocasionar uma redução na uniformidade de distribuição de água quando essa atinge o interior dos tubetes. A avaliação do sistema de irrigação mostrou um coeficiente de variação médio de $9,5 \%$ ao longo da faixa de trabalho e foi com essa variação que a água atingiu o dossel das plantas. Entretanto, quando mediu-se a lâmina infiltrada nos diferentes tubetes avaliados, verificou-se ao final do experimento que o coeficiente de variação aumentou para um valor médio de $32,8 \%$. Esses resultados mostraram que apesar de se ter um sistema com boa uniformidade de distribuição, a água atingiu o alvo (interior do tubete) com baixa uniformidade. Imaginemos que um viveirista possui um sistema de irrigação com boa uniformidade de distribuição (semelhante ao utilizado no experimento) e planeja fazer uma fertirrigação nas mudas. Com os resultados apresentados anteriormente, o viveirista poderia estar causando uma grande desuniformidade no estande, já que como os nutrientes acompanham a água de irrigação, as mudas estariam recebendo quantidades diferenciadas do nutriente aplicado.

\subsection{Desenvolvimento vegetativo}

Ao longo do período experimental, foram feitas quatro avaliações (57, 88, 118 e 149 DAR) das variáveis vegetativas altura, diâmetro do caule, área foliar e matérias secas da parte aérea e sistema radicular. Em virtude do elevado percentual de mortalidade das plantas, provocado pelo déficit hídrico dos tratamentos baseados na evaporação do minitanque, os resultados se limitaram apenas ao tratamento controle. As Figuras 14, 15 e 16 ilustram as variáveis vegetativas relacionadas com 0 desenvolvimento das mudas de cafeeiro ao longo do experimento. 

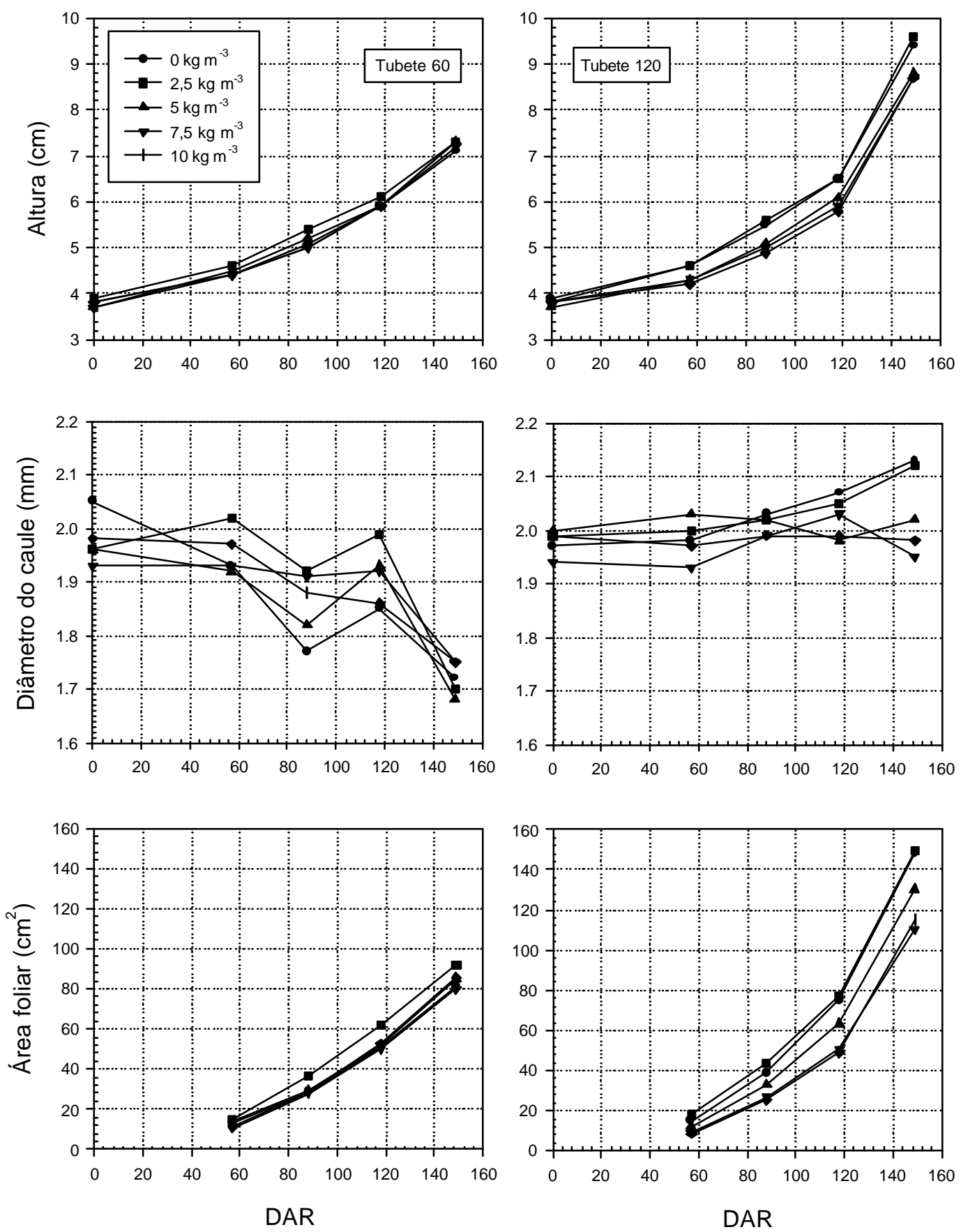

Figura 14 - Desenvolvimento vegetativo de mudas de cafeeiro irrigadas com a lâmina controle, cultivadas em substrato com diferentes doses do condicionador. Altura, diâmetro do caule e área foliar. 

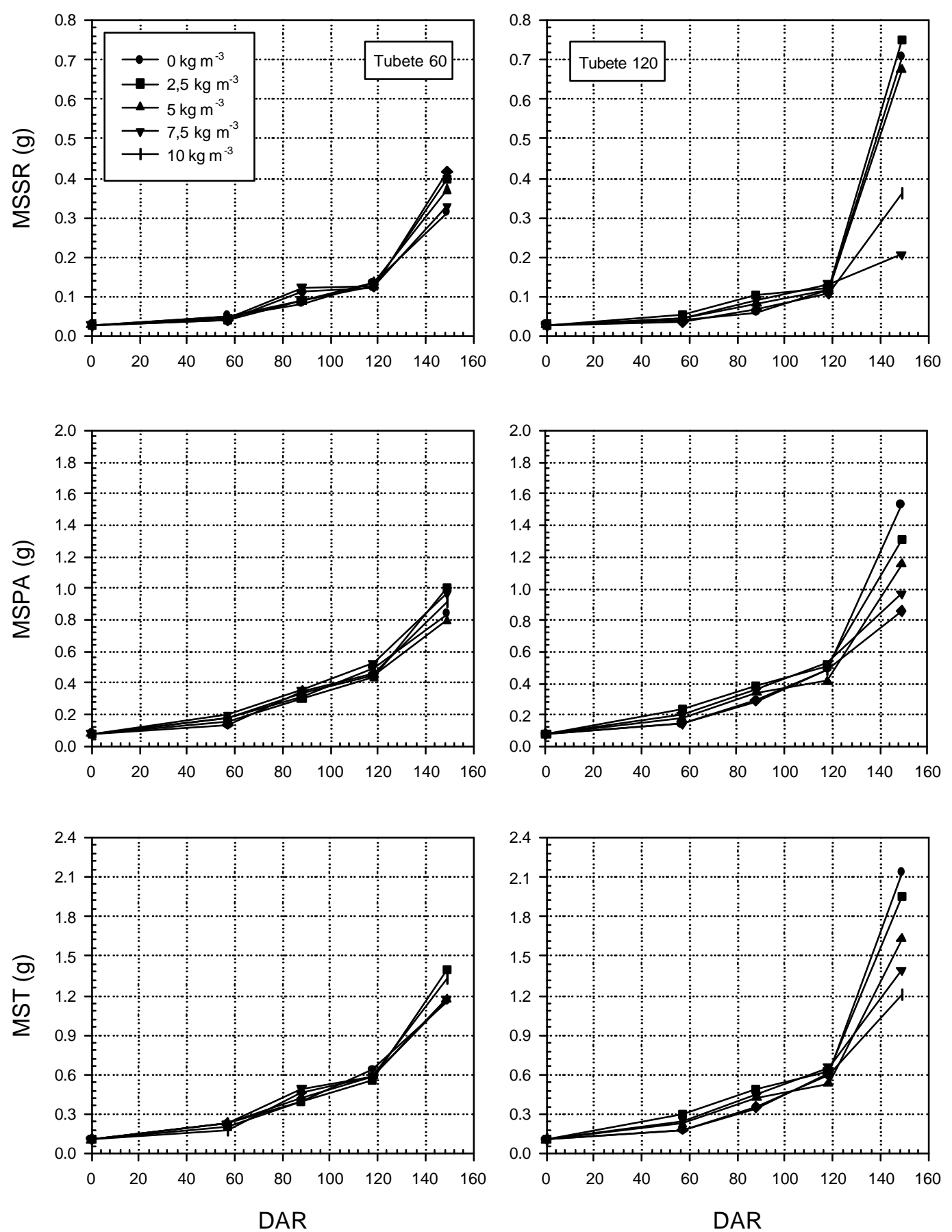

Figura 15 - Desenvolvimento vegetativo de mudas de cafeeiro irrigadas com a lâmina controle, em função de diferentes doses do condicionador. Matérias secas da parte aérea, sistema radicular e total. 

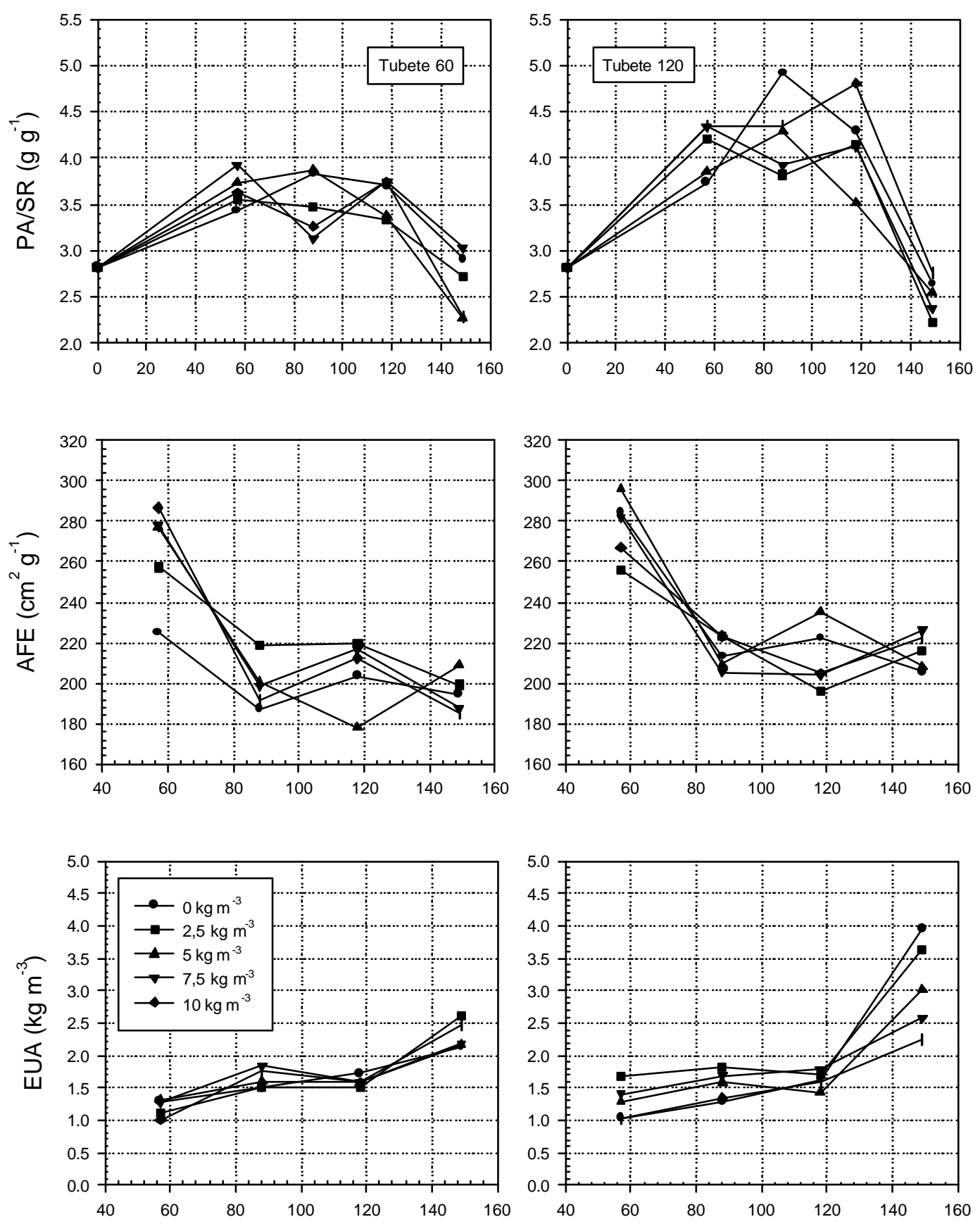

DAR

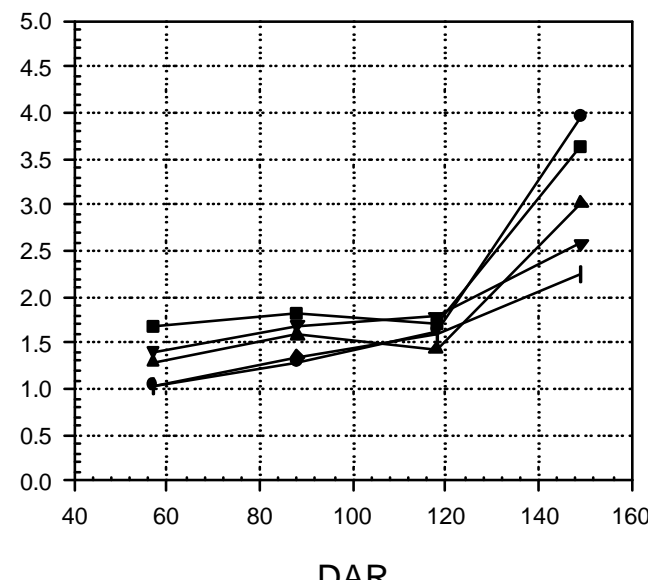

DAR

Figura 16 - Relação parte aérea-sistema radicular, área foliar específica e eficiência do uso da água de mudas de cafeeiro irrigadas com a lâmina controle, em função de diferentes doses do condicionador. 
Verificou-se que em todas as variáveis avaliadas, as mudas de cafeeiro que se desenvolveram nos tubetes de $120 \mathrm{~cm}^{3}$ foram superiores àquelas cultivadas nos tubetes de $60 \mathrm{~cm}^{3}$. Os tubetes maiores apresentam maior volume de substrato o que possibilitou maior disponibilidade de água e nutrientes. Entretanto as diferenças observadas foram significativas apenas para as variáveis altura, diâmetro do caule e área foliar (Tabela 8).

Tabela 8. Análise estatística das variáveis altura, diâmetro do caule e área foliar de mudas de cafeeiro, irrigadas com a lâmina controle, no final do experimento

\begin{tabular}{cccc}
\hline Tubete $\left(\mathrm{cm}^{3}\right)$ & \multicolumn{3}{c}{ Valores médios } \\
& Altura $(\mathrm{cm})^{2}$ & Diâmetro do caule $(\mathrm{mm})^{2}$ & Área foliar $\left(\mathrm{cm}^{2}\right)^{2}$ \\
\hline 60 & $7,27 \mathrm{~A}$ & $1,72 \mathrm{~A}$ & $84,49 \mathrm{~A}$ \\
120 & $9,04 \mathrm{~B}$ & $2,04 \mathrm{~B}$ & $130,74 \mathrm{~B}$ \\
\hline
\end{tabular}

${ }^{1}$ Média de 20 observações;

${ }^{2}$ Médias seguidas de mesma letra na coluna, não diferem entre si pelo teste de Scott-Knot a nível de $5 \%$ de probabilidade.

Embora não se tenha observado efeito significativo das doses do condicionador adicionado ao substrato, verificourse no tubete de $120 \mathrm{~cm}^{3}$, que a ausência do mesmo proporcionou um maior desenvolvimento vegetativo das mudas, quando comparado com o tratamento que recebeu a maior dose do produto $\left(10 \mathrm{~kg} \mathrm{~m}^{-3}\right)$, contrariando a expectativa inicial de que haveria um aumento no desenvolvimento vegetativo com a adição do condicionador. Entretanto, resultados similares foram encontrados por outros autores, embora tenham utilizado outro tipo de condicionador (Mendonça et al., 2002; Taylor \& Halfacre, 1986). 
A redução do diâmetro do caule, observada nas mudas cultivadas nos tubetes de $60 \mathrm{~cm}^{3}$, foi devido possivelmente a uma desidratação dos tecidos seguida de uma necrose, na região do colo da muda (Figura 17). Algumas mudas foram analisadas para verificar as causas desse sintoma e concluiu-se que o mesmo foi devido a fatores abióticos, já que em exames fitopatológicos não foi constatada a presença de patógenos.

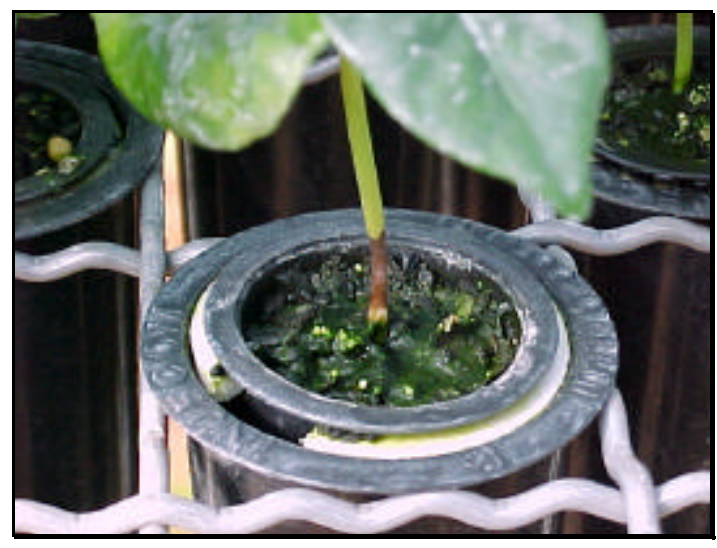

(a)

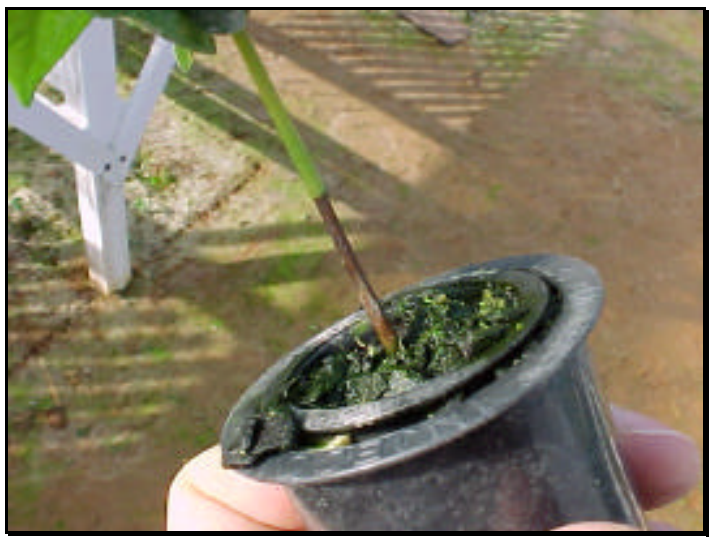

(b)

Figura 17 - Sintomas de necrose na região do colo em mudas de cafeeiro. Fase inicial (a) e estádio avançado estendendo-se ao longo do caule (b).

No período compreendido entre os 118 e 149 DAR, observou-se um aumento considerável no desenvolvimento das mudas de cafeeiro, principalmente em termos de altura, área foliar e produção de biomassa (MSPA, MSSR e MST). Esse incremento foi mais evidente nas mudas cultivadas nos tubetes de $120 \mathrm{~cm}^{3}$, refletindo nos valores da relação parte aérea e sistema radicular (PA/SR) e na eficiência do uso da água (EUA) (Figura 16). Nas avaliações realizadas até os 118 DAR, verificou-se que as mudas não desenvolviam o sistema radicular, mesmo nas plantas irrigadas com a lâmina controle. Nessa fase as raízes já deveriam ter ocupado grande parte do volume 
do tubete. Acredita-se que a causa dessa redução no desenvolvimento radicular foi a salinidade provocada pelo fertilizante de liberação controlada (Figura 18).

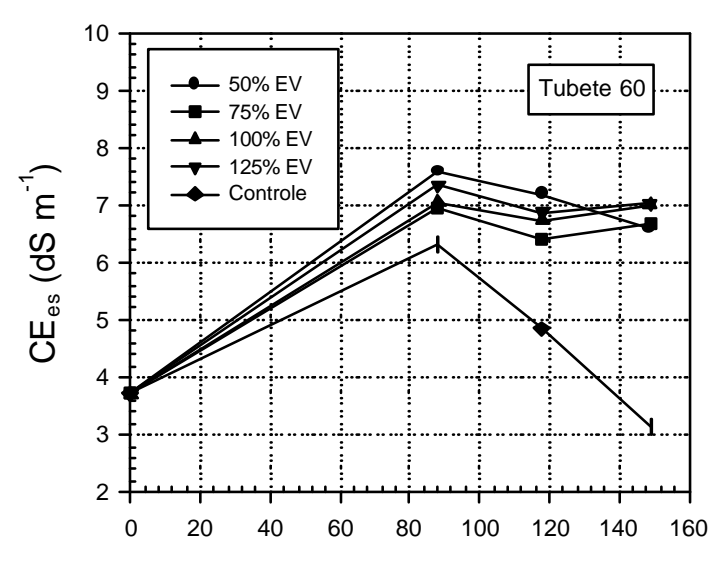

DAR

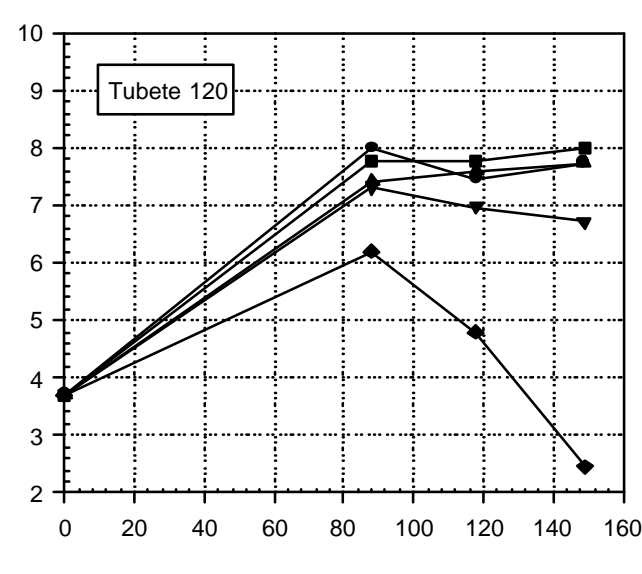

DAR

Figura 18 - Condutividade elétrica do extrato saturado do substrato ao longo do período experimental, sob diferentes lâminas de irrigação e tamanhos de tubetes.

O substrato comercial puro já apresentava uma condutividade elétrica do extrato saturado $\left(\mathrm{CE}_{\mathrm{es}}\right)$ de 3,71 $\mathrm{dS} \mathrm{m}^{-1}$. Segundo Ansorena Miner (1994), esse valor é considerado ligeiramente alto para a maioria das culturas, sendo adequado apenas para plantas vigorosas. No caso específico do cafeeiro, não há relatos na literatura informando os níveis adequados de condutividade elétrica do extrato saturado para o seu ótimo desenvolvimento. Essa carência de informações se justifica em função das características edafoclimáticas encontradas nas regiões produtoras de café, tais como solos profundos, bem drenados e com precipitações elevadas. Nessas condições, é pouco provável o aparecimento de problemas relacionados à salinidade, o que talvez não tenha despertado interesse da pesquisa com relação a esse aspecto. No caso específico da produção de mudas, ainda se utiliza o sistema de saquinhos na sua grande maioria. Nesse sistema o substrato é composto basicamente por $70 \%$ de terra retirada da camada subsuperficial do solo, apresentando assim 
baixa fertilidade. Além do maior volume dos saquinhos, a adubação de base também é menor quando comparada ao sistema de tubetes. Essas condições, aliadas a elevadas lâminas de irrigação minimizam os riscos de salinidade. Com a adoção do sistema de produção de mudas de cafeeiro em tubetes, é necessário que se inicie trabalhos relacionados à salinidade para quantificar os limites adequados ao desenvolvimento da cultura.

Aos 88 DAR, foram observados os maiores valores da $\mathrm{CE}_{\mathrm{es}}$, independente das lâminas de irrigação e tamanho de tubetes. Esses valores, acima de $6 \mathrm{dS} \mathrm{m}^{-1}$, podem levar a danos severos e provável perda do cultivo (Ansorena Miner, 1994). Acredita-se que esses resultados aliados à baixa lâmina de água aplicada pelos tratamentos baseados na evaporação do minitanque, foram os responsáveis pelo elevado percentual de mortalidade das mudas relativas a esses tratamentos. Entretanto, a partir desse período, verificou-se uma queda acentuada nos valores de $C E_{\mathrm{es}}$ quando da aplicação da lâmina controle. A diminuição da salinidade nesse período coincidiu com o aumento na taxa de crescimento das mudas, principalmente do sistema radicular, o que nos levou a acreditar que a sua pequena taxa de crescimento até os 118 DAR foi devido à elevada salinidade do substrato. Ao final do experimento (149 DAR) os valores de $\mathrm{CE}_{\mathrm{es}}$ do substrato foram de $3,15 \mathrm{dS} \mathrm{m}^{-1} \mathrm{e}$ $2,45 \mathrm{dS} \mathrm{m}^{-1}$, para os tubetes de $60 \mathrm{~cm}^{3}$ e $120 \mathrm{~cm}^{3}$, respectivamente. Esses valores encontram-se abaixo do limite superior de $3,49 \mathrm{dS} \mathrm{m}^{1}$, considerado ótimo para os substratos de cultivo (Abad et al., 1992).

Ao final do experimento, amostras de substrato foram enviadas ao laboratório para análise de fertilidade e os resultados encontram-se na Tabela 9. Observourse pequena variação entre as concentrações de nutrientes obtidas no início e final do experimento, principalmente para as lâminas de $50 \%$ EV e $125 \%$ EV, nos dois tamanhos de tubetes e para a lâmina controle no tubete de $60 \mathrm{~cm}^{3}$. No tratamento correspondente à lâmina controle associada ao tubete de $120 \mathrm{~cm}^{3}$, foram observadas reduções nas concentrações dos nutrientes, principalmente de nitrogênio, fósforo e potássio. Essas reduções podem ser 
explicadas em parte, pela absorção das plantas, o que refletiu no maior desenvolvimento das mudas nesse tratamento, e também pela possível lixiviação, principalmente do potássio, em função da lâmina de irrigação aplicada. Também verificou-se uma redução na concentração de sódio quando comparado ao valor inicial e demais tratamentos.

Tabela 9. Teores de macro e micronutrientes em função de lâminas de irrigação e tamanhos de tubetes

\begin{tabular}{|c|c|c|c|c|c|c|c|}
\hline \multirow{3}{*}{ Elemento } & \multirow{3}{*}{$\begin{array}{c}\text { Valor inicial }{ }^{1} \\
\quad(0 \mathrm{DAR})\end{array}$} & \multicolumn{6}{|c|}{ Valores finais (149 DAR) } \\
\hline & & \multicolumn{2}{|c|}{$50 \% \mathrm{EV}$} & \multicolumn{2}{|c|}{$125 \% \mathrm{EV}$} & \multicolumn{2}{|c|}{ Controle } \\
\hline & & 60 & 120 & 60 & 120 & 60 & 120 \\
\hline$\overline{\mathrm{N} \text { total }(\%)}$ & 1,25 & 1,17 & 1,18 & 1,18 & 1,09 & 1,10 & 0,87 \\
\hline $\mathrm{P}_{2} \mathrm{O}_{5}$ total $(\%)$ & 0,78 & 0,79 & 0,74 & 0,80 & 0,83 & 0,67 & 0,68 \\
\hline $\mathrm{K}_{2} \mathrm{O}$ total $(\%)$ & 1,13 & 1,47 & 1,26 & 1,16 & 1,04 & 1,04 & 0,41 \\
\hline Ca total (\%) & 1,07 & 1,15 & 1,05 & 1,16 & 1,08 & 1,01 & 0,97 \\
\hline Mg total (\%) & 1,84 & 1,73 & 1,76 & 1,70 & 1,70 & 1,71 & 1,72 \\
\hline S total (\%) & 0,39 & 0,38 & 0,45 & 0,40 & 0,39 & 0,28 & 0,25 \\
\hline Cu total $\left(\mathrm{mg} \mathrm{kg}^{-1}\right)$ & 40 & 42 & 42 & 43 & 39 & 42 & 41 \\
\hline Mn total $\left(\mathrm{mg} \mathrm{Kg}^{-1}\right)$ & 240 & 267 & 316 & 271 & 263 & 269 & 240 \\
\hline $\mathrm{Zn}$ total $\left(\mathrm{mg} \mathrm{kg}^{-1}\right)$ & 61 & 65 & 68 & 62 & 65 & 68 & 64 \\
\hline B total $\left(\mathrm{mg} \mathrm{kg}^{-1}\right)$ & 9 & 12 & 14 & 13 & 11 & 12 & 12 \\
\hline Na total $\left(\mathrm{mg} \mathrm{kg}^{-1}\right)$ & 497 & 542 & 484 & 543 & 480 & 481 & 357 \\
\hline
\end{tabular}

${ }^{1}$ Média de 5 repetições e valores expressos com base na amostra seca.

Amostras foliares também foram submetidas à análise laboratorial na tentativa de explicar a redução no desenvolvimento das mudas em função da toxicidade de alguns elementos (Tabela 10). Os resultados da análise mostraram que as concentrações de cloro, boro e sódio ficaram abaixo dos 
limites de toxidez apresentados por Smedema \& Rycroft (1983) e Malavolta et al. (1993). Também foi dbservada uma redução nos teores de sódio nas mudas que receberam a lâmina controle, provavelmente em conseqüência da menor concentração desse elemento encontrada no substrato. Possivelmente, a lâmina aplicada por esse tratamento possibilitou a lixiviação de certa quantidade desse elemento diminuindo a sua absorção pela planta. Esses resultados reforçam a hipótese de que os fatores que levaram ao elevado percentual de mortalidade das mudas foram a salinidade do substrato, provocada pelo fertilizante de liberação controlada, associada ìs reduzidas lâminas de irrigação.

Tabela 10. Teores foliares de cloro, sódio e boro $\left(\mathrm{mg} \mathrm{kg}^{-1}\right)$ em função da lâmina de irrigação

\begin{tabular}{lcccccc}
\hline \multirow{2}{*}{ Elemento } & $50 \% \mathrm{EV}$ & $75 \% \mathrm{EV}$ & $100 \% \mathrm{EV}$ & $125 \% \mathrm{EV}$ & Controle & $\begin{array}{c}\text { Toxidez } \\
\left(\mathrm{mg} \mathrm{kg}^{-1}\right)\end{array}$ \\
\hline Cloro & 100 & 200 & 200 & 100 & 100 & $>3000^{1}$ \\
Sódio & 1150 & 1610 & 1518 & 1311 & 989 & $>2500^{1}$ \\
Boro & 30 & 23 & 24 & 22 & 30 & $>90^{2}$ \\
\hline
\end{tabular}

${ }^{1}$ Limite de toxicidade apresentado por Smedema \& Rycroft (1983);

${ }^{2}$ Limite de toxicidade apresentado por Malavolta et al. (1993). 


\section{CONSIDERAÇÕES FINAIS}

Diante dos resultados obtidos e da experiência adquirida ao longo do experimento, serão apresentados alguns comentários com relação aos trabalhos atuais e algumas sugestões para novas pesquisas sobre a produção de mudas de cafeeiro em tubetes.

\subsection{Substratos para a produção de mudas}

A produção de mudas de cafeeiro passa por uma fase de transição, em que aos poucos, o sistema de produção em saquinhos vem sendo substituído pelo sistema de tubetes. Paralelamente, o substrato padrão utilizado nos saquinhos foi substituído por materiais orgânicos (principalmente cascas vegetais) quando da adoção do novo sistema de produção de mudas. A literatura apresenta uma série de trabalhos relacionados a substratos alternativos para a produção de mudas de cafeeiro e os resultados obtidos são bastante variados. Não é difícil imaginar as inúmeras combinações que podem ser feitas, tanto de materiais alternativos como de suas proporções na mistura. É possível utilizar o mesmo substrato e os resultados serem completamente diferentes dependendo do manejo adotado. De fato, todo substrato apresenta propriedades físicas e químicas que possibilitam o desenvolvimento das plantas de forma diferenciada. As propriedades físicas são mais importantes que as químicas, uma vez que selecionada a mistura como meio de cultivo, essas não podem ser modificadas. Já a composição química pode ser alterada durante 0 desenvolvimento da planta, mediante irrigação e adubação. Assim, seria 
interessante que nos trabalhos envolvendo substratos, os resultados de desenvolvimento da planta fossem expressos com base nas propriedades físicas e químicas do substrato. As plantas não respondem ao substrato e sim æ̀s condições que ele oferece ao seu desenvolvimento como por exemplo, balanço adequado entre aeração e disponibilidade de água, $\mathrm{pH}$, condutividade elétrica, balanço de nutrientes, entre outros fatores. Primeiro é preciso definir as condições ideais (físico-hídricas e químicas) para o desenvolvimento das mudas de cafeeiro e depois, numa segunda etapa, verificar se os materiais alternativos, disponíveis em cada região do país, atendem as necessidades da cultura.

\subsection{Manejo da irrigação}

Um dos objetivos do trabalho foi definir uma lâmina de irrigação que proporcionasse um bom desenvolvimento das mudas. Entretanto, as lâminas definidas no experimento, baseadas na evaporação do minitanque, ficaram abaixo das necessidades da planta. Apenas a lâmina controle proporcionou um desenvolvimento satisfatório das mudas, embora ainda seja necessário alguns ajustes.

Por outro lado, o experimento mostrou resultados muito peculiares ao sistema de produção de mudas em tubetes, especificamente com a cultura do cafeeiro. A primeira característica referese à disposição dos tubetes na bancada. Para a obtenção de um estande adequado, os tubetes são dispostos em fileiras alternadas e espaçados entre si de uma malha de tela. Como os tubetes estão suspensos, toda a água precipitada nesses espaços vazios é perdida, não sendo aproveitada pelas plantas. Por outro lado, no sistema de produção em saquinhos, esses são dispostos lado a lado no canteiro, de modo que os espaços vazios são bastante reduzidos. Assim, grande parte da água aplicada pelo sistema de irrigação infiltra no substrato. Uma outra característica, apresentada nos resultados e discussão, refere-se à eficiência da irrigação. Os 
resultados do trabalho mostraram que as mudas de cafeeiro, em condições ideais de desenvolvimento, apresentaram uma arquitetura foliar que possibilitou coletar um maior volume de água, direcionando-a para o interior do tubete. $\mathrm{O}$ problema não está na capacidade da planta em coletar mais água do que o necessário e sim na uniformidade com que essa água atinge o interior dos tubetes. Embora o sistema tenha apresentado um elevado coeficiente de uniformidade no momento em que a água atingiu o dossel das plantas, esse coeficiente caiu drasticamente quando a mesma atingiu o interior dos tubetes. As implicações práticas desse fenômeno refletem em desuniformidade do estande quer seja por falta ou excesso de água, lixiviação de nutrientes, ou outros fatores que venham a prejudicar o desenvolvimento das plantas. Devese atentar para esse fato quando se planeja aplicar fertilizantes via água de irrigação, pois como os nutrientes acompanham a água, quantidades diferenciadas do fertilizantes podem estar sendo aplicadas nas mudas.

Um outro aspecto importante está relacionado ao manejo da irrigação, mais especificamente aos equipamentos utilizados para quantificar a necessidade hídrica da planta. No experimento foi utilizado um minitanque de evaporação, onde quatro níveis de lâmina foram baseados num percentual equivalente à evaporação diária nesse equipamento. Ao final do experimento, chegourse à conclusão que esse equipamento não é o ideal para ser utilizado em sistemas de produção em recipientes, principalmente tubetes. Esses, particularmente para cultura do cafeeiro, apresentam um volume reduzido, de forma a armazenar um pequeno volume de água disponível æ̀s plantas. Assim, plantas cultivadas nesses recipientes estão mais sujeitas ao estresse em função de oscilações climáticas do ambiente. O minitanque de evaporação responde à demanda atmosférica mas não é capaz de identificar as condições reais de disponibilidade de água presente no substrato. Por exemplo, poder-seia colocar dois tubetes preenchidos com substratos com características físicas completamente diferentes, um com casca de arroz carbonizada com baixa capacidade de retenção e outro com turfa que apresenta boa capacidade de 
retenção. Nesse mesmo local seria instalado um tanque de evaporação para quantificar a demanda atmosférica local. O manejo da irrigação seria feito da mesma forma que o adotado no experimento, ou seja, aplicação de um percentual da evaporação numa freqüência diária. Seria provável que em um dia de elevada demanda atmosférica, a planta cultivada no substrato contendo casca de arroz carbonizada apresentasse sintomas de estresse hídrico, mesmo numa freqüência de irrigação diária. Isso mostra que o tanque de evaporação, apesar de quantificar a demanda local, não indica o momento em que se deve fazer a reposição, sendo esse uma decisão do irrigante. Assim, surge a proposta de se pesar os tubetes. Como visto anteriormente, cada material utilizado como substrato possui características diferenciadas em termos de retenção de água. Dessa forma, de posse de um substrato, o primeiro passo seria caracterizá-lo em termos de balanço ar-água e definir o volume de água disponível para a planta (Cadahía Lopez, 2000). Com a utilização de um sistema de pesagem baseado em célula de carga, seria feito um acompanhamento em tempo real da variação desse volume útil, fazendo com que o sistema de irrigação fosse acionado automaticamente, repondo o volume evapotranspirado. Dessa forma, a freqüência de irrigação seria variável e a lâmina de água fixa, sendo essa definida pela caracterização física do substrato que está sendo utilizado. Um outro inconveniente do tanque é que o mesmo ocupa um determinado espaço no viveiro, reduzindo a área útil utilizada para a produção das mudas.

Mesmo com a utilização do sistema de pesagem, ainda persiste o problema da desuniformidade da irrigação causada pelas folhas da planta. Uma outra alternativa seria a utilização de um sistema de subirrigação, onde o umedecimento do substrato presente nos tubetes seria feito por meio da ascensão capilar, após a formação de uma lâmina intermitente de água. $O$ sistema de produção de mudas de cafeeiro em tubetes apresenta uma série de características que podem viabilizar esse método de irrigação. Uma dessas características consiste no elevado número de tubetes por área, o que 
possibilita a otimização da área utilizada para a formação da lâmina de água. Um outro aspecto muito importante está relacionado à germinação das sementes de cafeeiro. A semeadura pode ser feita diretamente nos tubetes após as sementes passarem por um processo de embebição e atingirem 0 estádio de "protusão de radícula" ou indiretamente por meio do processo de repicagem. Com esse sistema de irrigação subsuperficial poder-se-ia pensar em fazer a semeadura direta e o processo inicial de embebição poderia ser feito com o próprio sistema de irrigação por intermédio da manipulação de uma lâmina de água, permitindo a saturação do substrato por um período de poucos dias. kso possibilitaria uma germinação uniforme e a obtenção de mudas sem problemas de "peão torto".

Outra vantagem desse método de irrigação, seria a possibilidade da prática da fertirrigação. Ao invés de se irrigar apenas com água, poder-se-ia preparar uma solução completa de nutrientes com condutividade elétrica baixa e suprir as necessidades nutricionais da planta ao longo do ciclo de produção. Esse sistema permite a manutenção da condutividade elétrica a níveis adequados, o que não ocorre quando se utiliza fertilizante de liberação controlada. Segundo o fabricante, o tempo de liberação está intimamente relacionado com a temperatura. Como na grande maioria dos viveiros de produção de mudas de cafeeiro não é feito o monitoramento das variáveis ambientais, principalmente da temperatura no interior do substrato, fica difícil controlar a liberação do fertilizante. A alternativa é aumentar a lâmina de irrigação a fim de lixiviar o excesso de sais. No caso deste experimento, utilizou-se uma adubação de base de $8,2 \mathrm{~kg} \mathrm{~m}^{-3}$. Embora os trabalhos mostrem que essa é a dose que proporciona um maior desenvolvimento vegetativo, esses mesmos trabalhos não mencionam a quantidade de água aplicada. Com exceção da lâmina controle, em todos os demais tratamentos baseados na evaporação do minitanque, as lâminas aplicadas foram insuficientes para suprir a demanda da planta. Aliada à falta de água, a liberação acelerada do fertilizante (em função de temperaturas elevadas) contribuiu para o aumento da 
salinidade do substrato e consequentemente para o elevado percentual de mortalidade das plantas. Acredita-se que as lâminas de irrigação utilizadas nos viveiros são elevadas quando se utiliza essa dose de adubação na base, permitindo que parte dos nutrientes sejam lixiviados.

O método de irrigação subsuperficial apresenta vantagens quando o substrato utilizado é composto por cascas vegetais. Essas cascas, principalmente a de pinus, apresentam características hidrofóbicas quando secas, sendo difícil o seu umedecimento. Com esse sistema, é possível criar um ambiente de saturação, possibilitando o umedecimento lento e uniforme desse tipo de material. Até mesmo a hidratação inicial dos polímeros hidroabsorventes pode ser feita com esse sistema, sendo mais difícil quando se utiliza o sistemas de microaspersão e barras lineares.

Acredita-se que muito pode ser feito em termos do manejo da irrigação em mudas de cafeeiro, como o estudo de sistemas alternativos, interações de lâminas e doses de fertilizantes, bem como a prática da fertirrigação.

\subsection{Utilização de condicionador na produção de mudas}

Os resultados obtidos com o condicionador em ensaios laboratoriais não foram os mesmos quando da sua aplicação ao substrato de cultivo. Isso se deve em parte, às próprias condições de cultivo que impossibilitam o seu desempenho potencial (Bowman et al., 1990; Fonteno \& Bilderback, 1993 e Wang \& Gregg, 1990). Algumas falhas de manejo também poderiam ser a causa de sua baixa efetividade, como por exemplo, a não adição de água quando do preparo da mistura em betoneira, umedecimento inicial não adequado após o enchimento dos tubetes, além do manejo inadequado da irrigação na fase de pegamento (100\% EV).

Algumas dificuldades foram encontradas na manipulação do condicionador utilizado no experimento. Por se tratar de uma mistura de componentes, a sua granulometria é muito variada, o que facilita a sua 
segregação. Assim, no ato da mistura, corre-se o risco de não aplicar de forma balanceada todos os componentes presentes no condicionador. Informações do mecanismo de absorção e suas interações com os demais componentes não são divulgadas pelo fabricante o que dificulta as interpretações dos resultados experimentais.

Quanto à forma de aplicação, o fabricante recomenda que o condicionador seja aplicado seco, sendo posteriormente hidratado por meio da irrigação. Resultados de pesquisa mostraram que nessas condições a hidratação do condicionador não ocorre em sua potencialidade, devido a resistência oferecida pelo substrato àsua expansão e também pela ausência de água livre responsável pela sua hidratação. Uma alternativa seria hidratá-lo previamente e depois misturá-lo ao substrato. Nessas condições deve-se tomar o cuidado para que seja colocada somente a quantidade de água necessária para a hidratação do condicionador (baseada na curva de absorção), uma vez que o mesmo apresenta alguns componentes na forma de pó (ativadores de enraizamento) que podem permanecer na solução caso seja adicionada quantidades excessivas de água.

A experiência adquirida nesse experimento não permite tirar conclusões definitivas em relação a utilização de condicionadores em substrato. Entretanto, quando o objetivo é retenção de água, os trabalhos mostram pouca eficiência quando esses condicionadores são adicionados aos substratos, principalmente se são constituídos apenas por polímeros hidroabsorventes. No caso dos condicionadores que apresentam outros componentes, como o utilizado nesse experimento, é possível que ocorra um efeito sinérgico, principalmente dos ativadores de enraizamento. Uma muda de qualidade é aquela que, quando transplantada, é capaz de resistir as adversidades climáticas que não são encontradas em condições de viveiro. Para que isso ocorra é preciso que essa muda apresente um bom desenvolvimento radicular, o que tornará mais rápido o seu estabelecimento no novo habitat. Novas pesquisas devem ser feitas para constatação dessa hipótese, pois embora a utilização desses condicionadores 
possam onerar o custo final da muda, a redução nos custos de replantio das mudas no campo pode reverter em benefício para o produtor. 


\section{CONCLUSÕES}

Nas condições em que o experimento foi conduzido conclui-se que:

- A utilização de evaporímetro não é um bom método para manejar a irrigação em viveiros de produção de mudas;

- Para o bom desenvolvimento de mudas de cafeeiros, são necessárias lâminas de irrigação superiores a $600 \mathrm{~mm}$, principalmente quando 0 umedecimento inicial do substrato não é adequado;

- A arquitetura foliar de mudas de cafeeiro afeta a eficiência da irrigação;

- O tubete de $120 \mathrm{~cm}^{3}$ possibilita um maior desenvolvimento vegetativo de mudas de cafeeiro;

- O maior desenvolvimento das mudas de cafeeiro ocorre quando os valores de condutividade elétrica do substrato saturado se encontram abaixo de 3 $\mathrm{dS} \mathrm{m}^{-1}$

- Não houve efeito de doses do condicionador no desenvolvimento das mudas de cafeeiro; 
- Quando o objetivo é a retenção de água, a atividade dos polímeros hidroabsorventes fica reduzida, quando os mesmos são adicionados em meios de cultivo intensivos. 


\section{ANEXOS}




\section{ANEXO A: MINITANQUE DE EVAPORAÇÃO AUTOMATIZADO}

\section{A.1 Aspectos construtivos}

Foi utilizado um minitanque com 0,6 m de diâmetro e 0,21 $\mathrm{m}$ de altura, contendo em seu interior um poço tranquilizador de 0,10 m de diâmetro. Esse minitanque foi assentado sobre um estrado de madeira de 0,62 x 0,62 $\mathrm{m}$, no qual foi instalado um suporte para fixação de um circuito sensor e de uma válvula solenóide.

Para reposição da água evaporada no minitanque, utilizou-se um tubo de PVC de $110 \mathrm{~mm}$ de diâmetro externo, espessura de parede de 0,6 mm e $1 \mathrm{~m}$ de comprimento. As dimensões desse tubo foram definidas com base na precisão de um conversor AD para a leitura de um sensor de pressão, bem como na sua autonomia para o reabastecimento do minitanque. O tubo de PVC foi fixado a um suporte metálico, ficando a sua base inferior a uma altura de $1 \mathrm{~m}$ da superfície do solo, o que permitiu o reabastecimento do minitanque pela ação da gravidade. Na base inferior desse tubo foi fixado um "cap" e instalado o sensor de pressão para leitura da carga hidráulica. Na face lateral do "cap" foi adaptado um conector de saída para instalação de uma mangueira de polietileno de 3/8", responsável pela condução da água até a válvula solenóide localizada junto ao minitanque. Na base superior do tubo foi utilizado um outro "cap", no qual foi feito um orifício de $5 \mathrm{~mm}$ de diâmetro para possibilitar a entrada da pressão atmosférica.

No poço tranquilizador do minitanque foi instalado um suporte para sustentação dos sensores de nível. Como sensores foram utilizados dois tipos de material, sendo um constituído de uma vareta de aço inoxidável de 1,5 mm de diâmetro e $8 \mathrm{~cm}$ de comprimento, permanentemente em contato com a água (imerso cerca de $1 \mathrm{~cm}$ ) e o outro, de uma agulha hipodérmica (encontrada nas redes de drogarias), responsável pelo acionamento do circuito eletrônico. Esses 
sensores foram instalados dentro de um tubo de acrílico que também funcionou como um poço tranquilizador, evitando que qualquer oscilação externa do nível d'água acionasse o circuito eletrônico. $\mathrm{Na}$ base superior desse tubo, foram feitos dois orifícios de $4 \mathrm{~mm}$ de diâmetro para a entrada do ar atmosférico, o que permitiu a ascensão da água dentro do mesmo. No centro da base inferior desse tubo, foi feito um orifício para permitir a entrada de água no seu interior. O diâmetro desse orifício $(3,5 \mathrm{~mm})$, definido em ensaios preliminares, proporcionou uma resposta rápida à retirada de água do minitanque e também evitou possíveis oscilações no nível de água causadas por ventos ou vibrações. A Figura A1 ilustra os componentes do minitanque automático.

\section{A.2 Automação do minitanque}

A automação foi dividida em duas etapas: controle automático do nível de água e leitura da lâmina evaporada por meio do sensor de pressão.

\section{A.2.1 Controle automático do nível de água}

Para o controle do nível de água no minitanque, utilizou-se um conjunto formado por um circuito sensor e uma válvula solenóide de 12 VCC, alimentados por uma bateria de $12 \mathrm{VCC}$. Foi utilizado o circuito sensor proposto por Van Roon (2002), o qual foi adaptado por meio da troca de um componente (transistor), adequando-o à lógica de funcionamento do minitanque. Esse circuito usa um sinal em corrente alternada para eliminar as corrosões eletrolíticas nos sensores, o qual é retificado e usado para ativar o transistor, responsável pelo chaveamento do relé. O esquema de montagem do circuito é apresentado na Figura A2. 


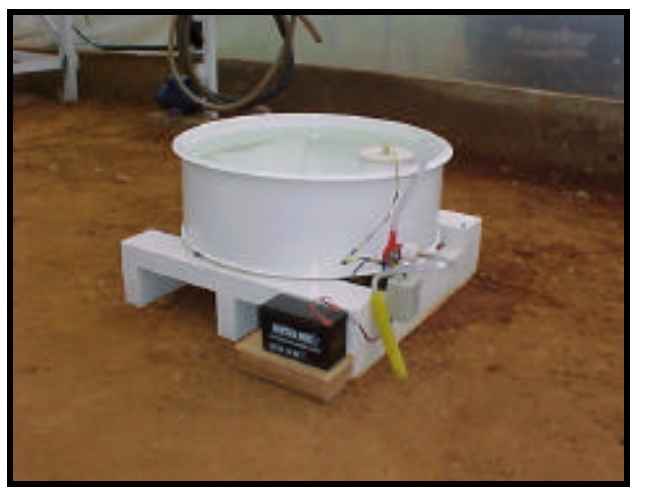

(a)

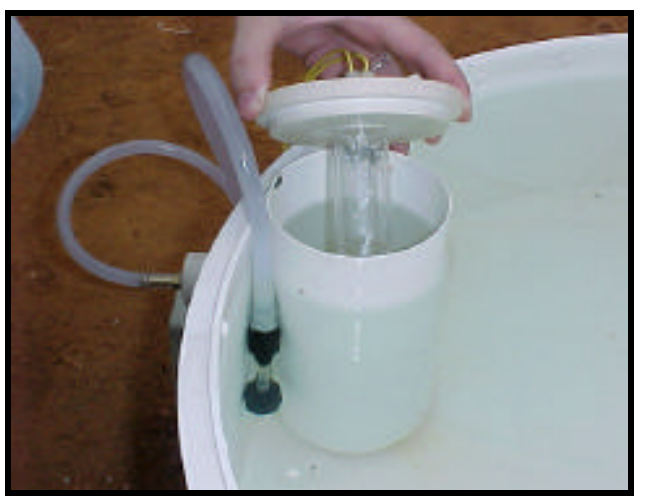

(c)

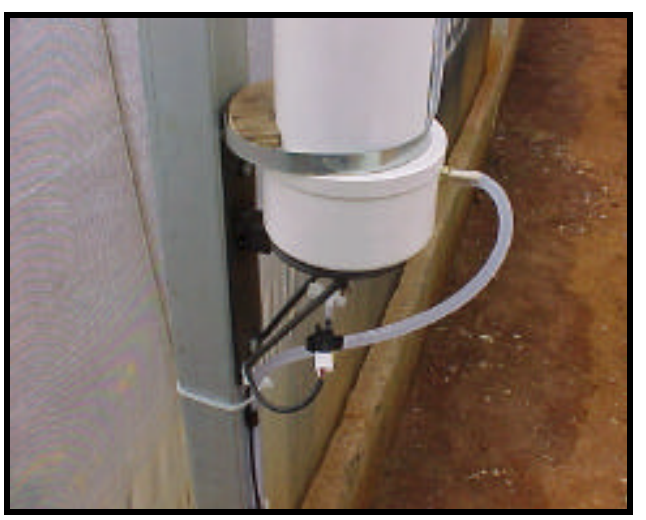

(d)

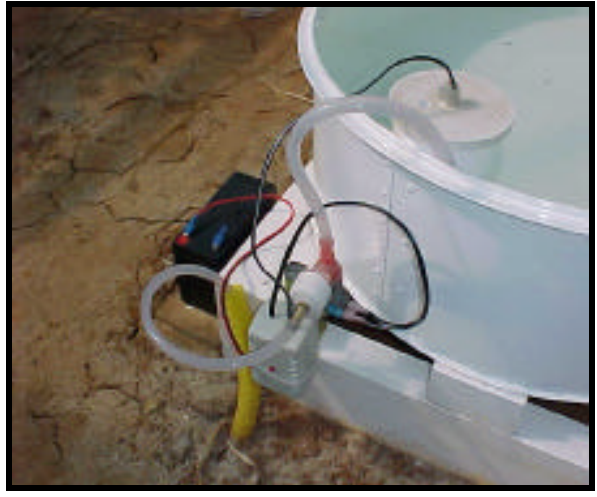

(b)

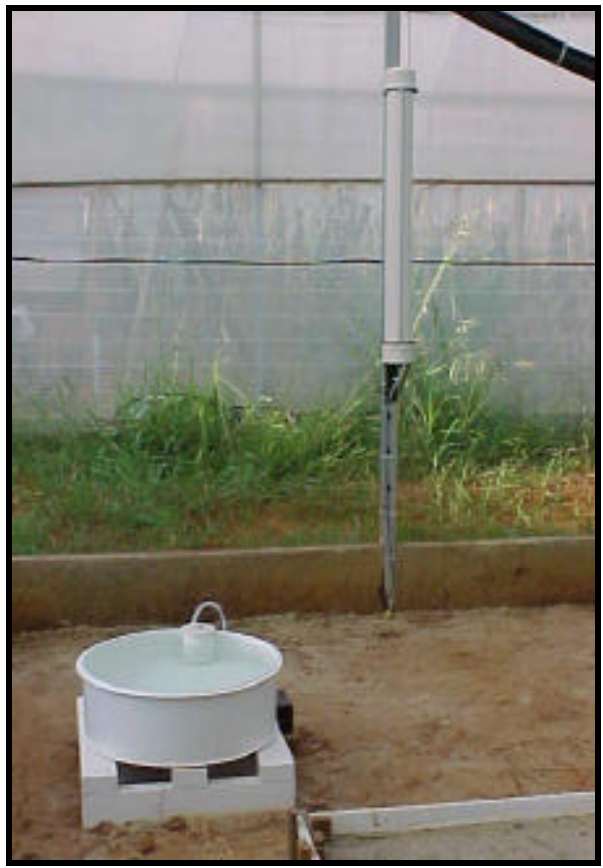

(e)

Figura A1 - Minitanque automático. Vista geral (a) e (e), válvula solenóide e circuito eletrônico (b), sensores de controle do nível de água (c) e sensor de pressão instalado na base inferior do tubo de PVC (d). 


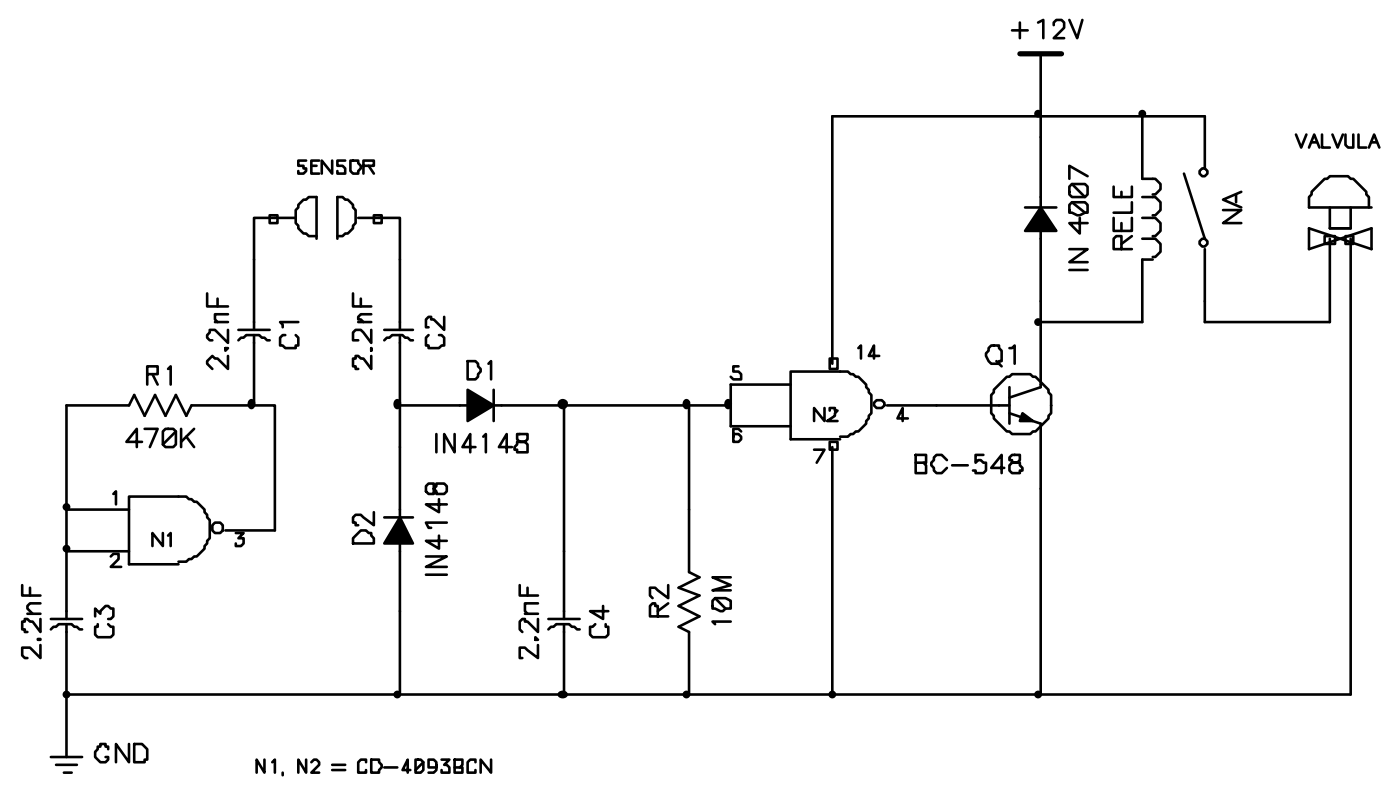

Figura A2 - Circuito eletrônico para controle do nível de água no minitanque.

Os dois sensores, ligados ao circuito eletrônico, permitiam a passagem de corrente elétrica quando em contato com a água, de forma a manter fechada a válvula solenóide. Com a evaporação, um dos sensores (agulha hipodérmica) ficava em contato com a atmosfera, acionando o circuito eletrônico que abria a válvula solenóide. Esse mecanismo permitia o reabastecimento do minitanque até que o mesmo sensor voltasse a tocar a superfície líquida. Estando os dois sensores novamente em contato com a água, o circuito eletrônico fechava a válvula, evitando o reabastecimento do minitanque.

\section{A.2.2 Leitura da lâmina de evaporação}

Para automatizar a leitura da lâmina evaporada, foi montado um sistema conforme diagrama ilustrado na Figura A3. 


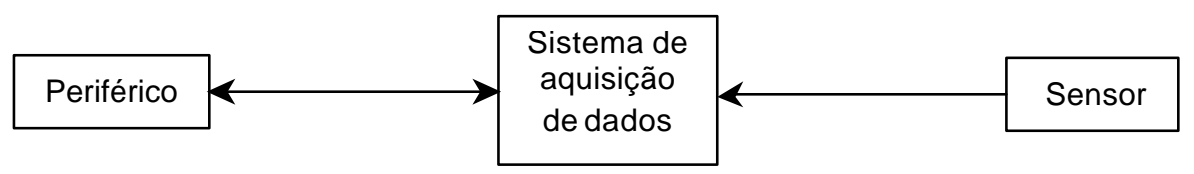

Figura A3 - Diagrama de inte rface de aquisição de dados.

Nesse sistema foi utilizado um sensor de pressão modelo MPX5010DP, cujas características de operação são encontradas no catálogo do fabricante (MOTOROLA, 2002). Com o reabastecimento do minitanque, ocorria uma diminuição do rível de água dentro do tubo no qual o sensor foi instalado. Em resposta a essa variação de nível, o sensor enviava um sinal analógico (0 a 5 V) para o sistema de aquisição de dados. Esse, por sua vez, tinha a função de converter o sinal analógico em digital (conversor A/D).

No sistema de aquisição de dados, foi utilizada uma placa comercial modelo ELCAS 2000 da empresa Solbet Ltda., a qual possui oito entradas analógicas de 8 bits de resolução, oito saídas digitais para acionamento de equipamentos e oito entradas digitais. Para a automação do minitanque foi utilizado apenas um canal analógico para a leitura do sensor de pressão, sendo as demais entradas analógicas e saídas digitais utilizadas na automação de outros componentes de um sistema de irrigação automatizado. Após a conversão do sinal, os dados na forma digital foram enviados para um periférico, que no caso desse trabalho, foi um microcomputador. Esses equipamentos são preferidos no controle de processos mais sofisticados, onde os dados enviados pelos sensores são utilizados na tomada de decisões ou até mesmo armazenados em um banco de dados para posterior manipulação. Uma outra alternativa é a utilização de microcontroladores, os quais podem ser programados para efetuar alguma tarefa, a partir de determinado valor lido pelo sensor. 


\section{A.2.3 Calibração do sensor}

A recepção do sinal digital pelo computador foi feita por meio de um software desenvolvido em linguagem Delphi 4.0, o qual recebeu os dados digitais da placa conversora por meio de comunicação serial. Com esse programa, foi possível determinar uma equação de calibração que descrevesse a variação do volume no tubo de PVC como função da variação de tensão lida no sensor de pressão. No ensaio de laboratório, encheu-se o tubo com água até o sensor acusar uma leitura próximo a $5 \mathrm{~V}$ (tensão máxima permitida na entrada analógica do conversor). Em seguida, realizaram-se drenagens sucessivas de água no tubo, obtendo-se novos pesos e valores de tensão, até o limite inferior de leitura do sensor (próximo a 0,2 V). A partir desse valor, realizoutse o processo inverso, por intermédio da reposição de água e leitura das variáveis peso e tensão. Esse procedimento foi repetido várias vezes para verificar a existência de histerese no sensor. A Figura A4 ilustra o ensaio laboratorial para obtenção da equação de calibração do sensor.

Com os dados obtidos no ensaio de calibração, ajustou-se a seguinte equação:

$$
\Delta \mathrm{Vol}=1661,9888 \Delta \mathrm{Te} \quad\left(\mathrm{R}^{2}=0,9989\right)
$$

em que:

$\Delta$ Vol - variação de volume no tubo de PVC, $\mathrm{cm}^{3}$;

$\Delta T e$ - variação da tensão no sensor, $V$ 


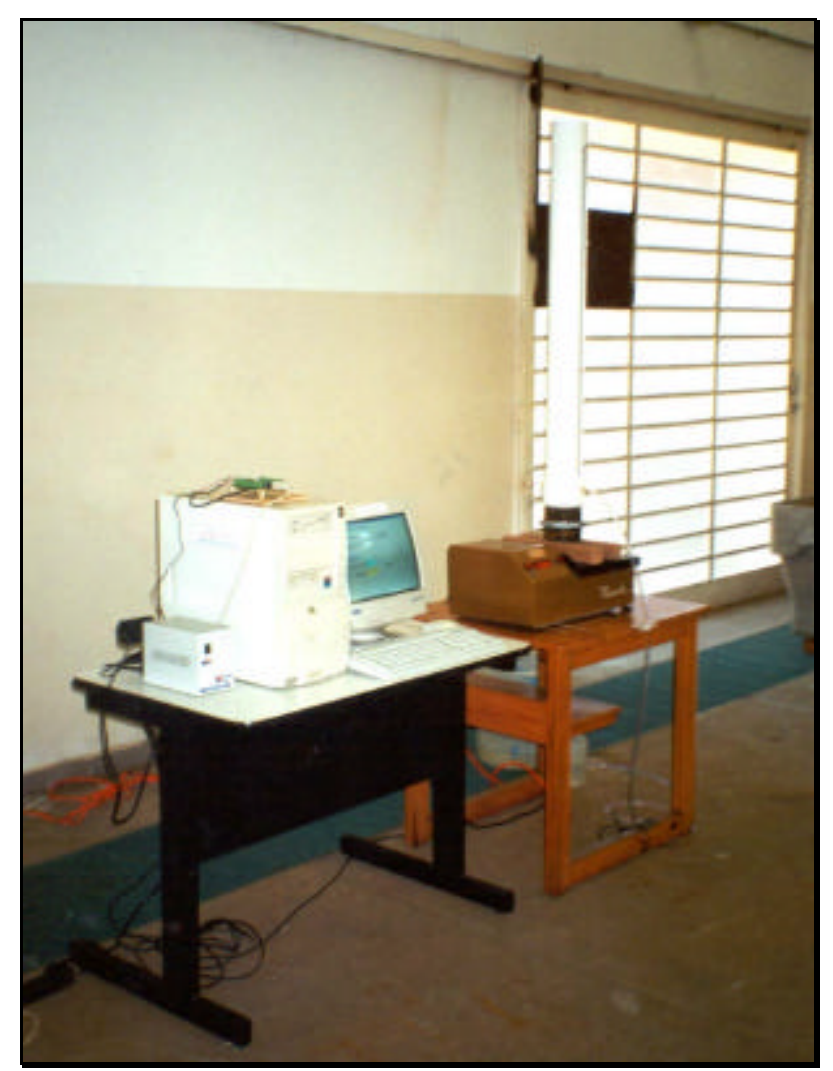

Figura A4 - Ensaio de laboratório para a obtenção da equação de calibração do sensor.

De acordo com a equação $A 1$, foi possível determinar a quantidade de água reposta no minitanque, dentro de um intervalo de tempo, a partir da leitura do sensor nesse mesmo período. Conhecendo-se esse volume e a área do minitanque, foi possível quantificar a lâmina evaporada. A equação descrita ainda permite determinar a precisão da leitura do sensor. Como foi utilizado um conversor $A / D$ de 8 bits ( $2^{8}$ bits $=256$ incrementos) e a tensão de saída do sensor varia de 0 a $5 \mathrm{~V}$, cada incremento correspondeu a uma variação de tensão de 0,0195 V. Pela equação, essa variação de tensão correspondeu a uma variação de volume de $32,46 \mathrm{~cm}^{3}$. O minitanque utilizado apresentou uma seção líquida de $2.748,89 \mathrm{~cm}^{2}$ (seção total descontada da seção do poço 
tranquilizador), de forma que cada incremento de variação na tensão representou uma variação de lâmina de $0,11 \mathrm{~mm}$. Essa seria a precisão de leitura no minitanque caso não houvesse erro na resposta do circuito ao reabastecimento de água. Ensaios mostraram que em média, a resposta da válvula ocorreu após a retirada de $67 \mathrm{~cm}^{3}$ de água, representando uma lâmina evaporada de aproximadamente 0,24 mm. Em situações onde são necessárias uma maior precisão, deve-se aperfeiçoar o mecanismo de resposta ao reabastecimento, para depois aumentar a precisão do conversor $A D$. Se a precisão fosse devida apenas à resolução do conversor e fosse utilizado um de 12 bits, a nova precisão, para a mesma configuração apresentada no trabalho, seria de aproximadamente $0,007 \mathrm{~mm}$. Conversores com essa resolução são mais caros que os utilizados nesse trabalho, de maneira que uma análise deve ser feita para se obter a melhor relação benefício/custo. Em termos de custo, estima-se que todo o sistema (minitanque e automação) apresenta um valor aproximado de $\cup \$ 230,00$. 


\section{ANEXO B: SISTEMA DE IRRIGAÇÃO AUTOMATIZADO}

\section{B.1 Desenvolvimento do sistema de irrigação}

O sistema foi composto de uma barra de irrigação (semelhante à barras de pulverização), acoplada a um carrinho metálico, responsável pelo seu deslocamento. Essa barra foi constituída por dois tubos de PVC de $3 \mathrm{~m}$ de comprimento e $25,4 \mathrm{~mm}$ de diâmetro, individualizados por duas válvulas solenóides. Em cada segmento de tubo foram instalados seis emissores tipo "leque" modelo TurboTeejet (SpraySystems ${ }^{\circledR}$ ), espaçados de $0,5 \mathrm{~m}$. Na condução do experimento, a barra foi ajustada a uma altura de $50 \mathrm{~cm}$ da superfície a ser irrigada.

Para a manutenção da pressão do sistema ao longo de toda a casa de vegetação, foi instalado um regulador de pressão de 103,42 kPa na junção dos dois segmentos da barra. No laboratório foram realizados testes para a determinação da vazão dos emissores nas pressões de 80, 100, 120 e 140 kPa. Utilizourse $100 \mathrm{kPa}$ como pressão de trabalho, o que representou em cada emissor, uma vazão média de $66 \mathrm{~L} \mathrm{~h}^{-1}$ (CV =0,73\%). Nesse teste foram selecionados 12 emissores, os quais apresentaram o menor desvio absoluto para a variável vazão. Esses foram divididos em dois grupos de seis para compor os dois segmentos da barra de irrigação e agrupados de forma a minimizar as diferenças entre os coeficientes de variação de vazão.

Após a construção da barra de irrigação, iniciou-se o desenvolvimento do carrinho e da estrutura metálica para o seu deslocamento. Nessa estrutura, utilizaram-se três barras metálicas com perfil tipo "U" (usada em portões), dispostas longitudinalmente em toda a extensão da casa de vegetação. As duas barras laterais serviram para a fixação e deslocamento do sistema de irrigação, por meio de rolamentos quádruplos. Na barra mediana foram instaladas cremalheiras (usadas em portões eletrônicos) para 0 acoplamento da 
engrenagem do moto-redutor ( $0,5 \mathrm{cv}$ e redução $1: 80)$, responsável pela tração do sistema de irrigação. Nessa mesma barra, foram distribuídos oito rolamentos quádruplos nos quais foi fixada uma mangueira flexível modelo Peti Rubber (Petiflex S.A.) com diâmetro nominal de $25 \mathrm{~mm}$, pressão nominal de 300 psi e $25 \mathrm{~m}$ de comprimento. Essa mangueira fez a conexão entre a motobomba (Linha Hydrobloc-KSB, modelo P 500, 0,5 cv, 3450 rpm, 220 VAC) e a barra de irrigação, movimentando-se junto com o sistema no momento das irrigações. Detalhes do sistema de irrigação podem ser vistos na Figura B1.

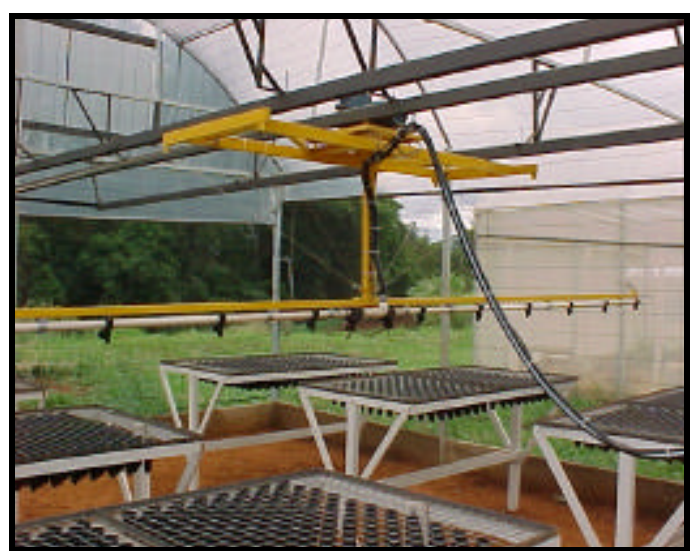

(a)

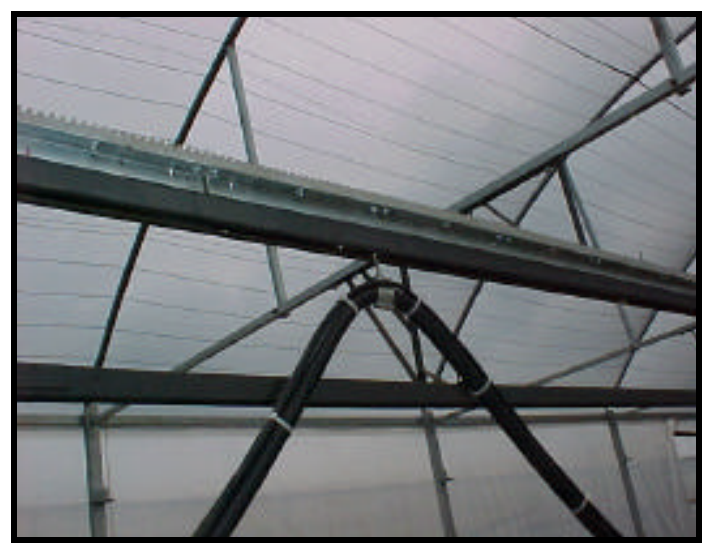

(b)

Figura B1 - Barra de irrigação acoplada ao carrinho (a); cremalheira e mangueira fixa ao rolamento (b).

\section{B.2 Automação do sistema de irrigação}

A automação da irrigação foi desenvolvida para atender um delineamento experimental com 5 tratamentos e 4 repetições, num total de 20 parcelas. Os tratamentos foram constituídos por lâminas de irrigação, cujos níveis representaram percentuais equivalentes à evaporação diária de um minitanque automatizado, localizado no interior da casa de vegetação. Cada parcela foi constituída por bancadas de madeira $(1,8 \times 1,0 \mathrm{~m})$, espaçadas uma 
das outras de 0,8 m. As bancadas foram distribuídas em duas fileiras paralelas (10 bancadas por fileira) espaçadas entre si de 1,4 m.

Para a automação do sistema de irrigação, foram utilizados vários componentes e o diagrama de funcionamento é apresentado na Figura B2.

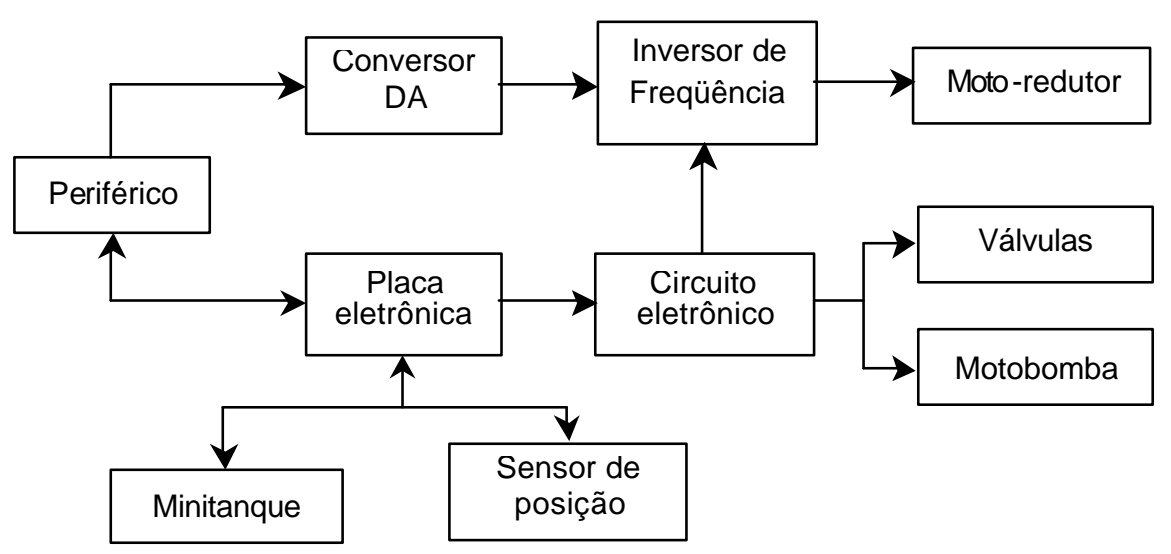

Figura B2 - Diagrama de funcionamento do sistema de irrigação automatizado.

O sistema de irrigação foi controlado por um microcomputador (periférico) mediante um programa desenvolvido na linguagem Delphi 4.0. Esse programa foi desenvolvido com o objetivo de controlar as irrigações durante todo o período experimental. A Figura B3 apresenta a tela principal do programa denominado "Viveiro". O programa permitiu operar, tanto manualmente como automaticamente, o sistema de irrigação. No controle manual foi possível acionar a motobomba, moto-redutor e as duas válvulas presentes na barra de irrigação. Esse modo de operação foi utilizado apenas na fase inicial de implantação do experimento e também em ocasiões de falha eletrônica, quando operado no sistema automático. Durante a aplicação dos tratamentos, o sistema foi controlado automaticamente, desde a leitura da evaporação no minitanque até a aplicação das diferentes lâminas de água. Nesse modo de controle, foi possível programar dois horários de funcionamento 
do sistema, de forma que a reposição diária da lâmina evapotranspirada fosse feita em duas frações iguais, aplicadas pela manhã e início da tarde. Ao final da irrigação vespertina, o programa disponibilizava, por meio de um relatório, todas as lâminas aplicadas em cada dia, além do total acumulado desde o início do experimento. Na seção "Status" era possível acompanhar, em tempo real, o estado de funcionamento de todos os equipamentos, bem como o número da bancada, tratamento e a respectiva lâmina de água aplicada. Ainda nessa seção, observa-se a presença de dois "leds", um de cor amarela e outro azul. O amarelo monitorava o sensor de posição presente no sistema de irrigação. Ele acendia toda vez que a barra de irrigação encontrava-se entre duas bancadas, indicando o momento em que a velocidade de deslocamento da barra deveria ser alterada, possibilitando a variação da lâmina a ser aplicada. O "led" de cor azul era ativado no momento da pressurização, o que acontecia no início do funcionamento de cada segmento da barra de irrigação.

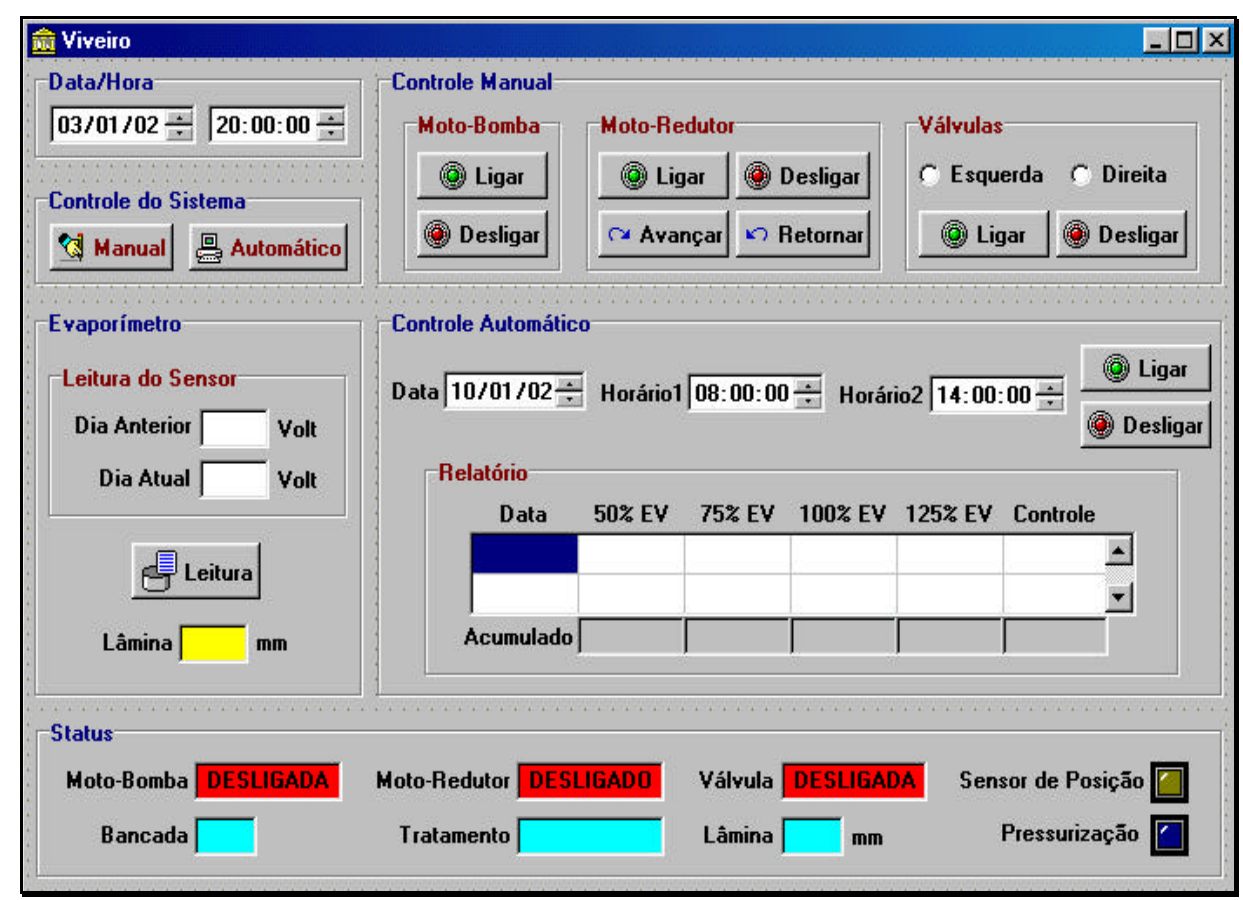

Figura B3 - Programa desenvolvido na linguagem Delphi 4.0 para automação do sistema de irrigação. 
$\mathrm{Na}$ interface periférico e circuito eletrônico foi utilizada uma placa eletrônica comercial modelo ELCAS 2000 da empresa Solbet Ltda., a mesma utilizada na automação do minitanque. Além do canal analógico destinado à leitura automática da lâmina evaporada no minitanque, foram utilizadas 5 saídas digitais para acionamentos dos componentes do sistema e uma entrada digital para monitoramento do sensor de posição.

Por meio de comunicação serial entre o periférico e a placa, o circuito eletrônico acionava a motobomba, o inversor de freqüência e permitia a abertura das válvulas solenóides presentes na barra de irrigação. Esse circuito foi composto por uma fonte de 127VAC/12VCC que alimentava os relés, um transformador 127VAC/24VAC para energização das válvulas solenóides e cinco circuitos ótico-isolados. Os circuitos ótico-isolados permitiam que 0 contato entre a placa eletrônica e o circuito eletrônico fosse feito sem a presença de fios elétricos. As Figuras B4 e B5 ilustram os diagramas de montagem do circuito com os respectivos componentes eletrônicos.

O inversor de freqüência, modelo Micromaster 420 (Siemens ${ }^{\circledR}$ ), trifásico e potência de $0,75 \mathrm{cv}$, comandava o moto-redutor (acionamento e reversão) por meio de sinais externos provenientes do circuito eletrônico. Esse inversor também tinha como função, variar a velocidade de deslocamento da barra de irrigação. A variação da velocidade era feita automaticamente por meio de um conversor DA (digital-analógico) modelo CIO-DAC02 (COMPUTERBOARDS ${ }^{\circledR}$ ). A partir de um sinal digital emitido pelo microcomputador, o conversor DA o transformava em sinal analógico (tensão), alimentando a entrada analógica do inversor de freqüência. Esse ao receber o sinal, emitia um correspondente valor de freqüência para o moto-redutor, alterando a velocidade de deslocamento da barra de irrigação. 


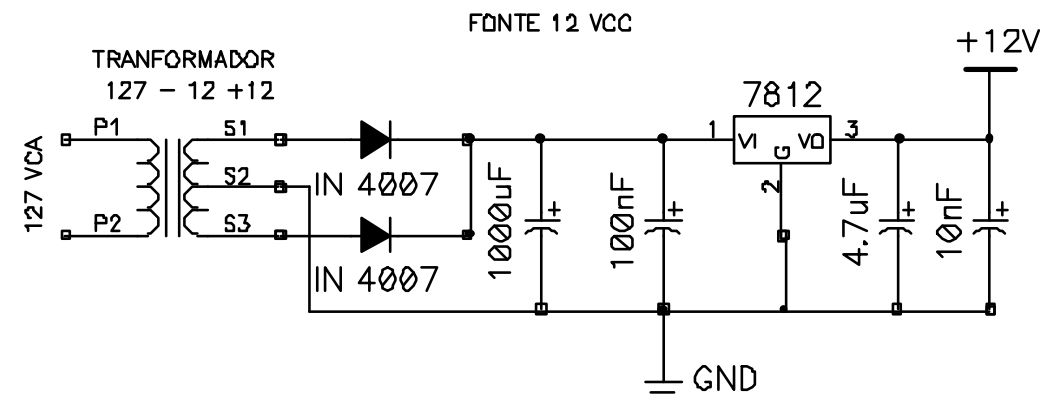

(a)

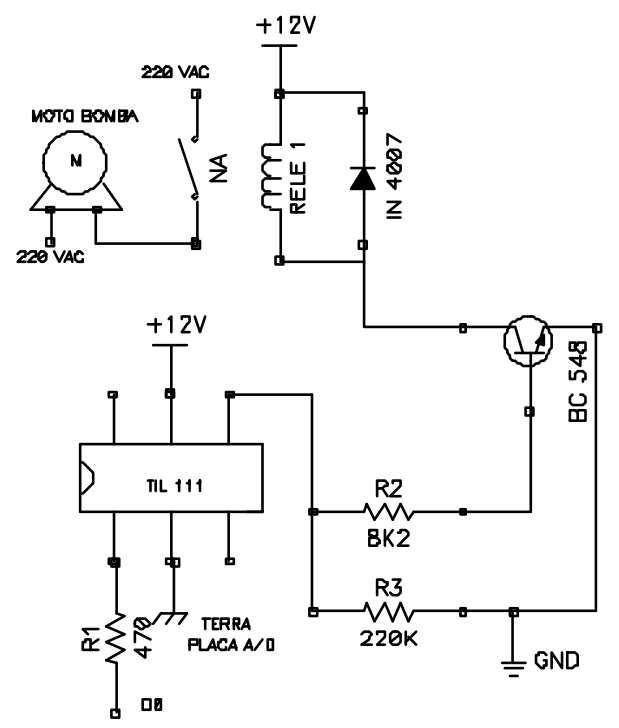

(b)

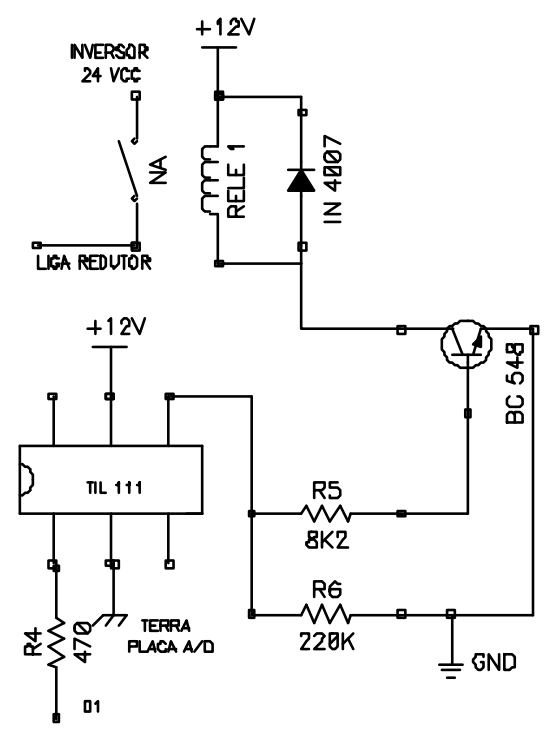

(c)

Figura B4 - Fonte 127VAC/12VCC (a); circuito ótico-isolado para ligar a motobomba (b); circuito ótico-isolado para ligar o moto-redutor (c). 


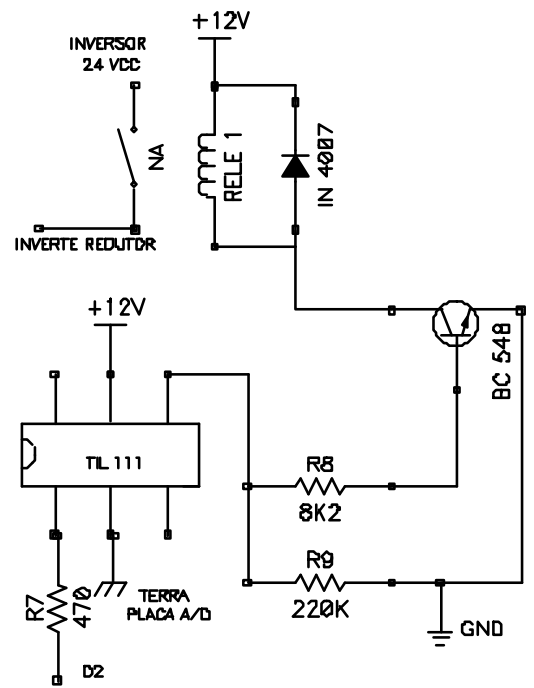

(a)

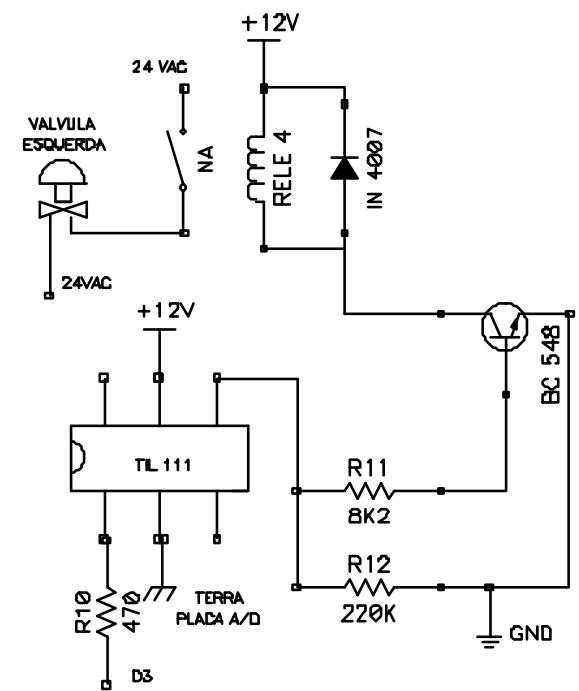

(b)

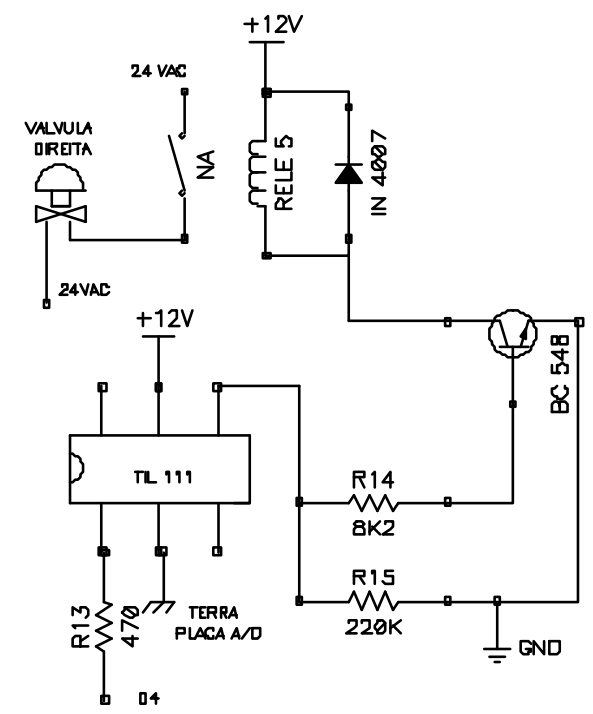

(c)

Figura B5 - Circuito ótico-isolado para inverter o sentido de rotação do motoredutor (a); circuito ótico-isolado para ligar a válvula solenóide esquerda (b); circuito ótico-isolado para ligar a válvula solenóide direita (c). 


\section{B.3 Avaliação do sistema de irrigação}

O sistema de irrigação foi avaliado com o objetivo de determinar a uniformidade de aplicação de água. Além da uniformidade, essa avaliação permitiu a obtenção de uma equação que foi incorporada no programa "Viveiro", com o intuito de definir a velocidade de deslocamento da barra de irrigação como função da lâmina de água a ser aplicada. No inversor, a mudança de freqüência foi feita por meio da alteração do sinal analógico em sua entrada. Já no conversor DA, a mudança do sinal analógico foi feita por meio de um sinal digital emitido pelo programa gerenciador. Esse sinal digital pode ser expresso por uma série de números inteiros, que no caso do modelo de conversor utilizado, variou de 0 a 2048. Assim, procurou-se obter uma equação que descrevesse a velocidade da barra (representada pelo número inteiro) em função da lâmina a ser aplicada.

$\mathrm{Na}$ avaliação, foram colocados 58 coletores, representados por tubetes de produção de mudas $(3,8 \mathrm{~cm}$ de diâmetro e $14 \mathrm{~cm}$ de altura), dispostos em três fileiras ao longo de uma bancada. Com a variação da velocidade de deslocamento da barra, foram obtidas as respectivas lâminas de irrigação. Cada teste foi repetido três vezes, totalizando-se para cada velocidade, 174 valores de lâmina. Com os pontos coletados, ajustoutse uma equação que descreveu o sinal digital enviado pelo programa como função da lâmina de irrigação a ser aplicada.

Os resultados da avaliação do sistema de irrigação são apresentados na Tabela B1. 
Tabela B1. Resultados da avaliação do sistema de irrigação

\begin{tabular}{cccc}
\hline Sinal Digital (decimal) & Lâmina média $(\mathrm{mm})^{1}$ & ${\text { CV }(\%)^{2}}^{2}$ & ${\text { CUC }(\%)^{3}}^{3}$ \\
\hline 240 & 0,32 & 13,36 & 89,72 \\
625 & 0,33 & 12,91 & 90,00 \\
1010 & 0,48 & 12,43 & 91,73 \\
1250 & 0,56 & 10,52 & 92,25 \\
1370 & 0,59 & 9,99 & 92,26 \\
1490 & 0,82 & 8,21 & 93,60 \\
1610 & 0,91 & 8,42 & 93,13 \\
1730 & 1,34 & 11,52 & 92,28 \\
1760 & 1,47 & 7,46 & 93,83 \\
1790 & 1,67 & 7,56 & 93,84 \\
1820 & 1,87 & 7,88 & 93,36 \\
1850 & 2,16 & 7,94 & 93,29 \\
1880 & 2,64 & 8,10 & 92,94 \\
1910 & 3,29 & 8,14 & 93,02 \\
1940 & 4,83 & 7,98 & 93,11 \\
1970 & 6,97 & 9,66 & 91,86 \\
\hline
\end{tabular}

${ }^{1}$ Média de 174 coletores;

${ }^{2}$ Coeficiente de variação;

${ }^{3}$ Coeficiente de Uniformidade de Christiansen.

Verificou-se que o sistema de irrigação apresentou um CUC acima de $90 \%$ em praticamente toda a faixa de trabalho. Observou-se também que esse sistema possibilita a aplicação de uma lâmina que varia de 0,32 a 6,97 $\mathrm{mm}$, em apenas uma operação. A elevada uniformidade de aplicação de água, aliada a sua ampla faixa de trabalho, permite a utilização desse sistema em 
ensaios experimentais cujo enfoque é o estudo de lâminas de irrigação no desenvolvimento de plantas.

Com os pontos obtidos na avaliação do sistema de irrigação, ajustaram-se as seguintes equações:

$$
\text { SD }=1937,310337-\frac{283,429721}{\text { LAM }^{1,5}} \quad\left(R^{2}=0,9820\right)
$$

ou:

$$
\mathrm{V}=0,8215+\frac{3,4408}{\text { LAM }^{1,5}} \quad\left(\mathrm{R}^{2}=0,9910\right)
$$

em que:

SD - sinal digital, decimal;

$\mathrm{V}$ - velocidade de deslocamento da barra de irrigação, $\mathrm{cm} \mathrm{s}^{-1}$;

LAM - lâmina de irrigação, mm

Com a equação B1, descrita acima, foi possível automatizar a velocidade de deslocamento da barra de irrigação a partir da leitura automática da lâmina evaporada no minitanque.

A Figura B6 ilustra o perfil de distribuição da barra de irrigação. Verificou-se um reduzido padrão molhado (aproximadamente $40 \mathrm{~cm}$ ), característica dos emissores tipo "leque". O perfil de distribuição, de forma triangular, apresentou uma elevada intensidade de aplicação (IA) a uma distância de $15 \mathrm{~cm}$ do emissor. Quando são utilizados sistemas com elevadas intensidades de aplicação de água, recomenda-se que as irrigações sejam parceladas para evitar as perdas por escoamento, principalmente em recipientes com reduzida área de coleta como os tubetes. 


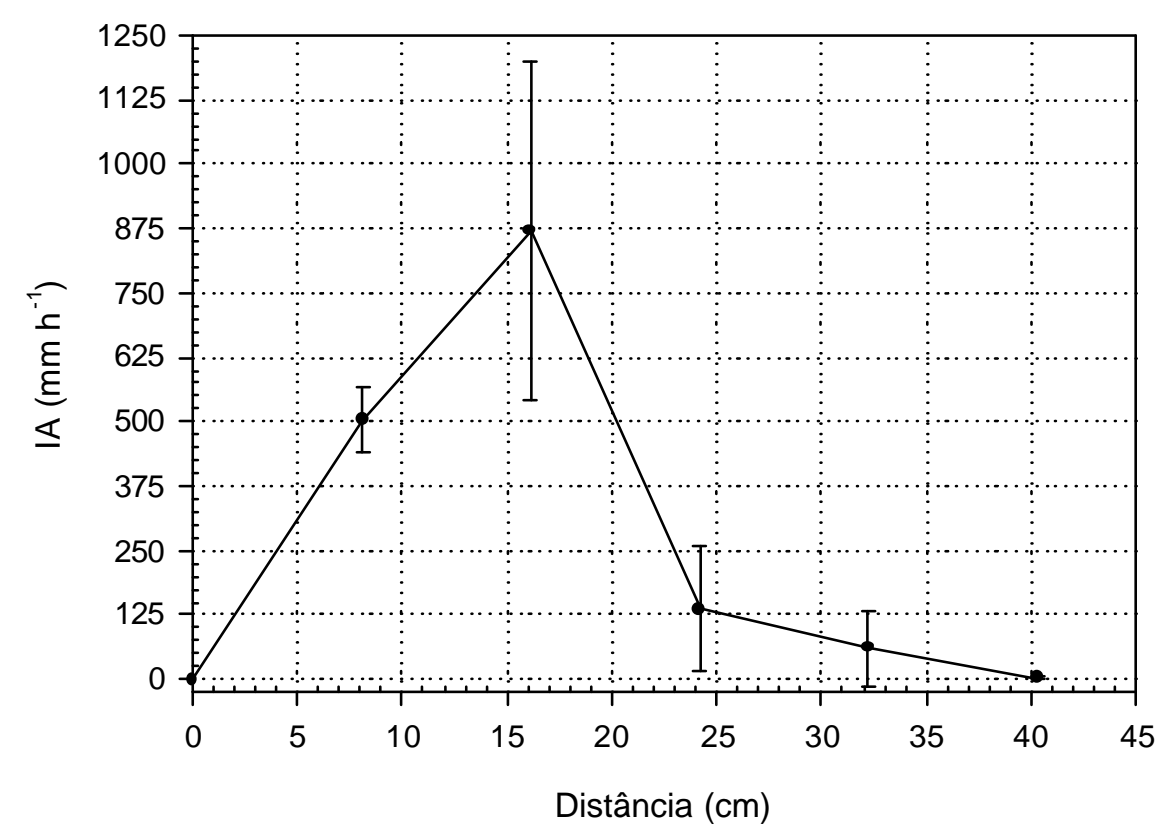

Figura B6 - Perfil de distribuição de água da barra de irrigação.

A utilização desse sistema de irrigação em condições comerciais ficará limitada em função dos aspectos construtivos do viveiro. Viveiros construídos em módulos geminados necessitam de um sistema de irrigação para cada módulo, o que pode inviabilizar economicamente, a utilização desse tipo de equipamento.

\section{B.4 Funcionamento do sistema de irrigação}

O sistema de irrigação era acionado duas vezes ao dia, aplicando um percentual da evaporação diária registrada pelo minitanque. Pela manhã, próximo ふ̀ 8:00 horas, era feita a leitura automatizada da lâmina diária evaporada, seguida da programação dos horários de irrigação (8:00 e 12:00 h) e habilitação do controle automático. Nesse instante, o programa calculava as lâminas correspondentes a cada tratamento e no horário previsto para a primeira irrigação, acionava a motobomba e a válvula direita da barra de irrigação. Após a pressurização do sistema, o moto-redutor era acionado para 
que a barra de irrigação se deslocasse a uma velocidade capaz de aplicar a lâmina corresponde ao tratamento da primeira bancada. Entre cada bancada existia um sensor de posição (relé reed) que indicava ao programa o momento da alteração da velocidade da barra. A Figura B7 ilustra o sensor de posição instalado na plataforma do carrinho.

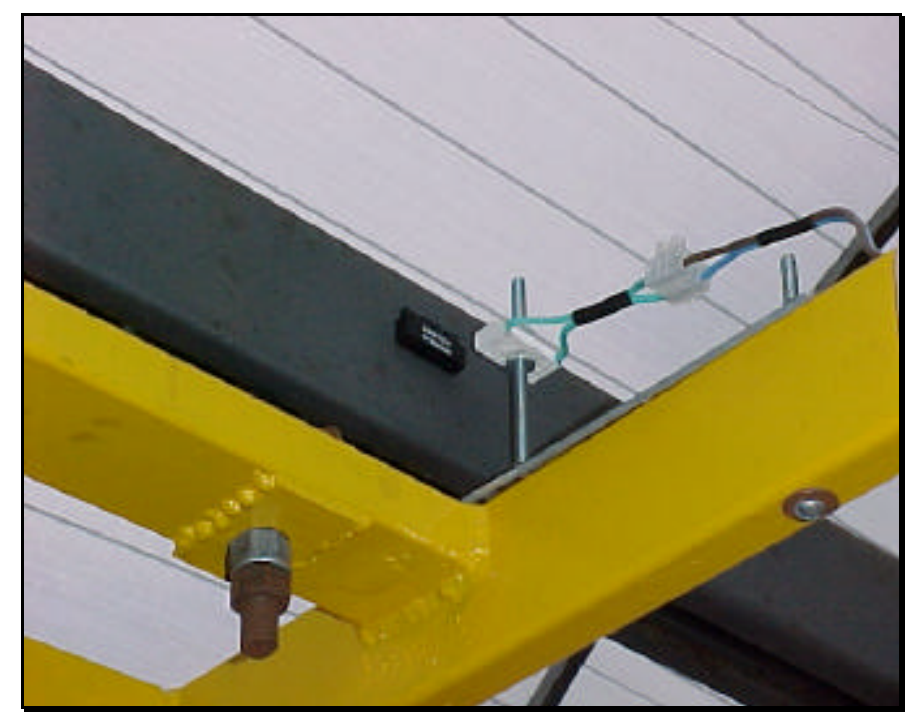

Figura B7 - Detalhe do sensor de posição e do imã responsável pelo fechamento do circuito.

Essa rotina era feita até o final da casa de vegetação, aplicando-se os tratamentos correspondentes æ̀ dez primeiras bancadas. Ao final da décima bancada, o programa desligava a válvula direita e ativava a esquerda. Nesse instante, o moto-redutor era desligado até que o segmento esquerdo da barra fosse pressurizado. Em seguida, o moto-redutor retornava deslocando a barra de modo que a irrigação fosse realizada nas últimas dez bancadas. Ao final desse procedimento, o sistema era desligado, permanecendo assim até o horário da segunda irrigação (12:00h), repetindo todo o processo descrito anteriormente. Após a irrigação diária, todos os valores das lâminas aplicadas eram disponibilizados na tela do programa e salvos em um arquivo tipo texto para posterior manipulação. 


\section{REFERÊNCIAS BIBLIOGRÁFICAS}

ABAD, M.; MARTíNEZ-HERRERO, M.D.; MARTíNEZ-GARCÍA, P.F.; MARTÍNEZ-CORTE, J. Evaluación agronómica de los sustratos de cultivo. Actas de Horticultura, v.11, p.141-154, 1992.

AL-DARBY, A.M. The hydraulic properties of a sandy soil treated with gelforming soil conditioner. Soil Technology, v.9, p.15-28, 1996.

AL-HARBI, A.R. Efficacy of a hydrophilic polymer declines with time in greenhouse experiments. HortScience, v.34, n.2, p.223-224, 1999.

ANDRADE NETO, A de. Avaliação de substratos alternativos e tipos de adubação para produção de mudas de cafeeiro (Coffea arabica L.) em tubetes. Lavras, 1998. 65p. Dissertação (Mestrado) - Universidade Federal de Lavras.

ANSORENA MINER, J. Sustratos: propriedades y caracterización. Bilbao: Ediciones Mundi-prensa, 1994. 172p.

AUSTIN, M.E.; BONDARI, K. Hydrogel as a field medium amendment for blueberry plants. HortScience, v.27, n.9, p.973-974, 1992. 
BARBIZAN, E.L.; SANTOS, C.M.; MENDES, A.F.; LANA, R.M.Q.; SANTOS, V.L.M.; MENDONÇA, F.C.; CORREIA, N.M.; ZAGO, R. Utilização de substrato comercial e fertilizantes de liberação lenta na produção de mudas de cafeeiro em saquinhos. In: ENCONTRO NACIONAL SOBRE SUBSTRATO PARA PLANTAS, 1., Porto Alegre, 1999. Anais. Porto Alegre: UFRGS, 1999. p.225-233.

BARROS, R.S.; MAESTRI, M.; VIEIRA, M.; BRAGA FILHO, L.J. Determinação da área de folhas do café (Coffea arabica L. cv. 'Bourbon Amarelo'). Revista Ceres, v.20, n.107, p.44-52, 1973.

BOWMAN, D.C.; EVANS, R.Y.; PAUL, J.L. Fertilizer salts reduce hydration of polyacrylamide gels and affect physical properties of gel-amended container media. Journal of the American Society for Horticultural Science, v.115, n.3, p.382-386, 1990.

CADAHÍA LOPEZ, C. Fertirrigacion: cultivos hortícolas y ornamentales. 2.ed. Madrid: Ediciones Mundi-Prensa, 2000. 475p.

CARNEIRO, J.G.A. de. Produção e controle de qualidade de mudas florestais. Curitiba: UFPR,FUPEF, 1995. 451p.

CHATZOUDIS, G.K.; VALKANAS, G.N. Lettuce plant growth with the use of soil conditioner and slow-release fertilizers. Communications in Soil Science and Plant Analysis, v.26, n.15/16, p.2569-2576, 1995.

DANNEELS, P.; VAN COTTHEM, W. The effect of a soil conditioning mixture on plant growth. Belgian Journal of Botany, v.127, n.1, p.17-25, 1994. 
FONTENO, W.C.; BILDERBACK, T.E. Impact of hydrogel on physical properties of coarse-structured horticultural substrates. Journal of the American Society for Horticultural Science, v.118, n.2, p.217-222, 1993.

GEHRING, J.M.; LEWIS, A.J. Effect of hydrogel on wilting and moisture stress of bedding plants. Journal of the American Society for Horticultural Science, v.105, n.4, p.511-513, 1980.

GUIMARÃES, P.T.G.; ANDRADE NETO, A. de; BELLINI JÚNIOR, O.; ADÃO, W.A.; SILVA, E.M. da. A produção de mudas de cafeeiros em tubetes. Informe Agropecuário, v.19, n.193, p.98-109, 1998.

HANDRECK, K.A. Particle size analysis and the physical properties of growing media for containers. Communications in Soil Science and Plant Analysis, v.14, n.3, p.209-222, 1983.

HEDRICK, R.M.; MOWRY, D.T. Effect of synthetic polyelectrolytes on aggregation, aeration and water relationships of soils. Soil Science, v.73, p.427-441, 1952.

JOHNSON, M.S. Effect of soluble salts on water absorption by gelforming soil conditioners. Journal of the Science of Food and Agriculture, v.35, p.1063-1066, 1984.

KÄMPF, A.N. Seleção de materiais para uso como substrato. In: KÄMPF, A.N.; FERMINO, M.H. Substrato para plantas: a base da produção vegetal em recipientes. Porto Alegre: Genesis, 1999. p.139-145.

LAMONT, G.P.; O'CONNELL, M.A. Shelf-life of bedding plants as influenced by potting media and hydrogels. Scientia Horticulturae, v.31, p.141-149, 1987. 
LIBARDI, P.L. Dinâmica da água no solo. 2.ed. Piracicaba: Editado pelo autor, 2000.509p.

MALAVOLTA, E.; FERNANDES, D.R.; ROMERO, J.P. Seja o doutor do seu cafezal. Piracicaba: POTAFOS, 1993. 12p. (Informações Agronômicas, 64)

MARIN, F.R.; ANGELOCCI, L.R.; COELHO FILHO, M.A.; VILLA NOVA, N.A. Construção e avaliação de psicrômetro aspirado de termopar. Scientia Agricola, v.58, n.4, p.839-844, out./dez. 2001.

MELO, B de. Estudos sobre produção de mudas de cafeeiro (Coffea arabica L.) em tubetes. Lavras, 1999. 119p. Tese (Doutorado) - Universidade Federal de Lavras.

MENDONÇA, F.C.; TEODORO, R.E.F.; LIMA, L.M.L. de; FERNANDES, D.L.; CORDEIRO, M.G.; NOVAES, Y.N. Produção de mudas de café (Coffea arabica L.) cv. Acaiá em tubetes com polímero hidroabsorvente adicionado ao substrato. In: SIMPÓSIO BRASILEIRO DE PESQUISA EM CAFEICULTURA IRRIGADA, 5., Araguari, 2002. Anais. Araguari: UFU, 2002. p.167-171.

MILNER, L. Manejo de irrigação e fertirrigação em substratos. In: FURLANI, A.M.C.; BATAGLIA, O.C.; ABREU, C.A.; FURLANI, P.R.; QUAGGIO, J.A.; MINAMI, K. Caracterização, manejo e qualidade de substratos para a produção de plantas. Campinas: Instituto Agronômico, 2002. p.45-51. (IAC. Documentos, 70). 
MIRANDA, S.C.; MELO, L.C.G.; RICCI, M.S.F. Substratos alternativos para produção de mudas de cafeeiro em tubetes. In: SIMPÓSIO DE PESQUISA DOS CAFÉS DO BRASIL, 2., Vitória, 2001. Anais. Vitória: EMBRAPA, 2001. p.175.

MOTOROLA. Integrated silicon pressure sensor, on-chip signal conditioned, temperature compensated and calibrated. http://www.mot co.jp/SPS/html/ lit/pdf/mpx5010.rev9.pdf. (10 Jan. 2002)

OLIVEIRA, P.S.R.; GUALBERTO, R.; FAVORETO, A. J. Efeito do osmocote adicionado ao substrato plantmax na produção de mudas de café em tubetes. In: CONGRESSO BRASILEIRO DE PESQUISAS CAFEEIRAS, 21., Caxambu, 1995. Anais. Caxambu: PROCAFE-DENAC, 1995. p.70-72.

PEREIRA, A.R.; ANGELOCCI, L.R.; SENTELHAS, P.C. Agrometeorologia: fundamentos e aplicações práticas. Guaíba: Livraria e Editora Agropecuária, 2002. 478p.

POZZA, A.A.A.; GUIMARÃES, P.T.G.; POZZA, E.A.; ROMANIELLO, M.M.; MARTINS, M.F. Suprimento do fertilizante de liberação lenta na produção de mudas de cafeeiro em tubetes. In: SIMPÓSIO DE PESQUISA DOS CAFÉS DO BRASIL, 1., Poços de Caldas, 2000. Anais. Poços de Caldas: EMBRAPA, 2000. p.1458-1461.

PREVEDELLO, C.L.; BALENA, S.P. Efeitos de polímeros hidrorretentores nas propriedades físico-hídricas de dois meios porosos. Revista Brasileira de Ciência do Solo, v.24, p.251-258, 2000. 
RIGAS, F.; SACHINI, E.; CHATZOUDIS, G.; KANELLOPOULOS, N. Effects of a polymeric soil conditioner on the early growth of sunflowers. Canadian Journal of Soil Science, v.79, p.225-231, 1999.

SILVA, E.M. da; CARVALHO, G.R.; ROMANIELLO, M.M. Mudas de cafeeiros: tecnologias de produção. Belo Horizonte: EPAMIG, 2000. 56p. (EPAMIG. Boletim Técnico, 60).

SILVA, N.; GONZALES, R.; RIOS, M.; LOPEZ, A.V. manejo del riego en viveros de café en el Tercer Frente, Santiago de Cuba. Revista Baracoa, v.21, n.2, p.7-21, 1991.

SMEDEMA, L.K.; RYCROFT, D.W. Planning and design of agricultural drainage systems. Cornell: Cornell University Press, 1983. 376p.

TAYLOR, K.C.; HALFACRE, R.G. The effect of hydrophilic polymer on media water retention and nutrient availability to Ligustrum lucidum. HortScience, v.21, n.5, p.1159-1161, 1986.

TERRACOTTEM. Guia técnico 1.0. Pinhais, s.d. 45p.

VAN ROON, T. Fluid-level sensor. http://www.uoguelph.ca/ antoon/circ/ sensor3.htm. (20 Jan. 2002)

WANG, Y.; GREGG, L.L. Hydrophilic polymers - their response to soil amendments and effect on properties of a soilless potting mix. Journal of the American Society for Horticultural Science, v.115, n.6, p.943-948, 1990.

WENDLING, I.; GATTO, A. Substratos, adubação e irrigação na produção de mudas. Viçosa: Aprenda Fácil Editora, 2002. 166p. 